\title{
Bakteriális partnerek által elősegített foto- fermentatív hidrogéntermelés Chlamydomonas algában
}

Ph.D. értekezés

Lakatos Gergely

Témavezető: Dr. Maróti Gergely

Biológia Doktori Iskola

MTA SZBK Biokémia Intézet

SZTE TTIK

2015.

Szeged 


\section{Tartalom}

Rövidítések jegyzéke ................................................................................................................ 3

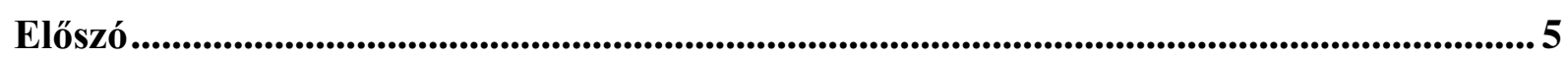

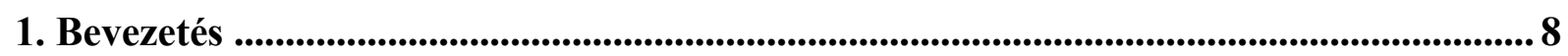

1.1. A hidrogén jelene és jövője ................................................................................. 8

1.2. Biohidrogéntermelö algák ..................................................................................... 10

1.3. A biológiai hidrogéntermelés lehetőségei ................................................................. 11

1.3.1. A biohidrogéntermelés általános jellemzése......................................................... 11

1.3.2. A hidrogenázok csoportjai és tulajdonságai .................................................... 12

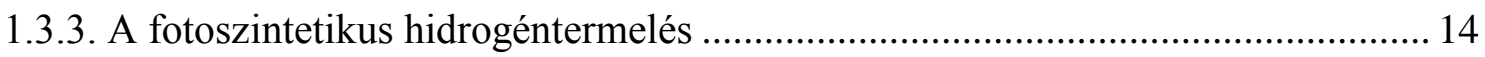

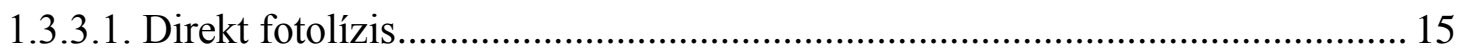

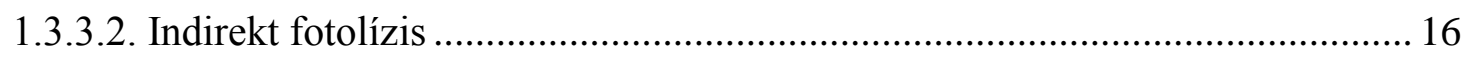

1.3.4. Sötét fermentáció Chlamydomonas törzsekben ..................................................... 18

1.3.5. Hidrogéntermelés alga-baktérium konzorciumokkal .............................................. 20

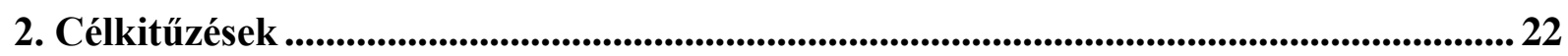

3. Anyagok és módszerek ......................................................................................................... 23

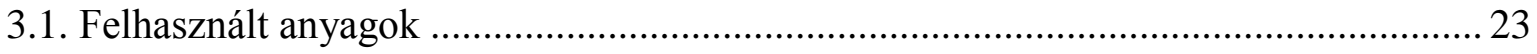

3.2. Alga kultúrák biomassza növekedésének vizsgálata .................................................... 26

3.3. Tiszta és kevert kultúrák növesztése ...................................................................... 27

3.4. A természetes bakteriális partnerek meghatározása ……………………………….... 28

3.5. Az alga és baktérium sejtszámok meghatározása ........................................................ 28

3.6. Hidrogén és oxigén analitikai mérése..................................................................... 29

3.7. Az oldott oxigén koncentrációjának meghatározása .................................................... 29

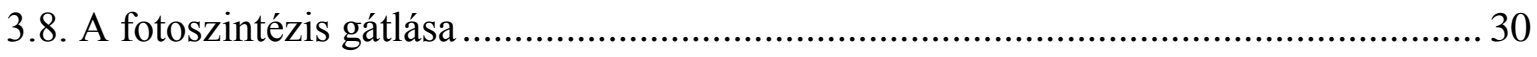

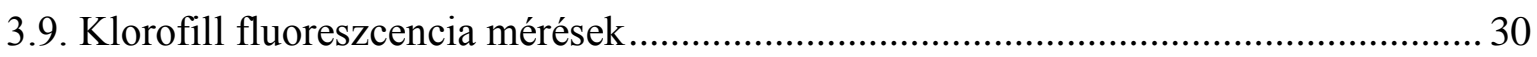

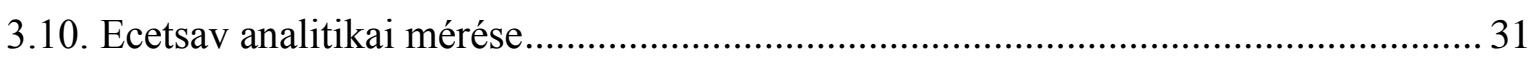

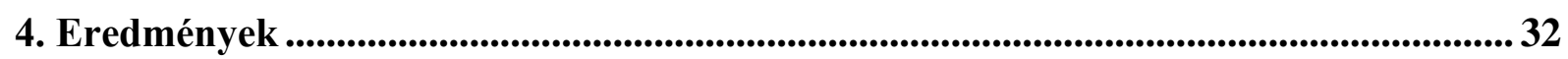

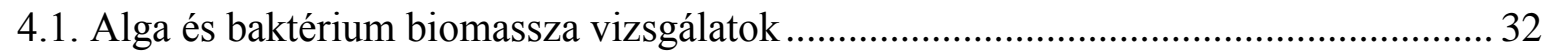

4.1.1. Chlamydomonas törzsek biomassza hozamának vizsgálata .................................. 32

4.1.2. A Chlamydomonas sp. 549 természetes bakteriális fertőzéseinek vizsgálata .......33

4.1.3. Természetes bakteriális partnerek hatása az alga biomassza növekedésére ..........37

4.2. Biohidrogéntermelés vizsgálatok .......................................................................... 39

4.2.1. Természetes bakteriális partnerek hatása az alga hidrogéntermelésére................. 39 
4.2.2. Az alga-baktérium arányok változtatásának hatása a hidrogéntermelésre 40

4.2.3. Hidrogéntermelő partner meghatározása vad típusú és hidrogenáz deficiens baktérium törzsekkel

4.2.4. Mutáns és vad típusú bakteriális partnerek hatásának vizsgálata a vegyes és tiszta kultúrák oxigénszint változására 47

4.2.5. Hidrogéntermelés Chlamydomonas sp. 549 és Ch. reinhardtii cc124 kevert algabaktérium törzsekkel 48

4.2.6. Oxigénszint változás a vegyes és tiszta alga és baktérium kultúrákban 49

4.2.7. Az oldott oxigénszint változása kevert és tiszta kultúrákban .50

4.3. A kultúrák folyadékfázisának analitikai vizsgálata .................................................... 52

4.3.1. Ecetsavfogyás tiszta alga és kevert alga-baktérium kultúrákban.........................52

4.3.2. Tiszta alga és baktérium, illetve kevert kultúrák $\mathrm{pH}$ változásai ..........................53

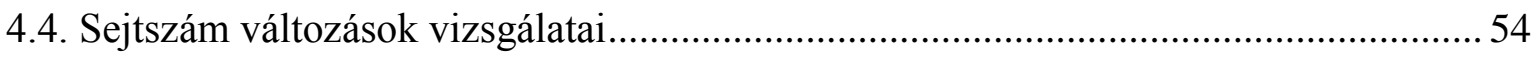

4.4.1. Fényen és sötétben inkubált minták optikai denzitásának változásai ................... 54

4.4.2. Alga sejtszám változás fényen és sötétben, TAP és TP tápban ............................55

4.4.3. Bakteriális sejtszám változás fényen és sötétben.............................................. 57

4.5. Az alga-baktérium konzorciális hidrogéntermelés kombinálása fermentatív és kénmegvonáson alapuló hidrogéntermelő megközelítésekkel ...................................58

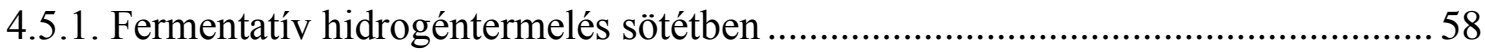

4.5.2. Hidrogéntermelés kénmegvonás útján tiszta és bakteriális partnert tartalmazó

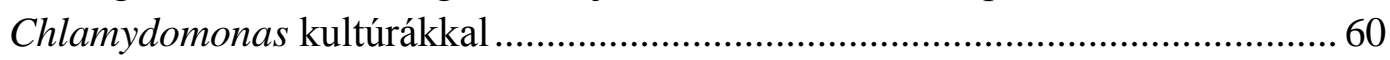

4.6. A fotoszintetikus rendszer vizsgálata a hidrogéntermelés során ................................63

4.6.1. PSII müködésének vizsgálata klorofill fluoreszcenciás mérésekkel ....................63

4.6.2. Az alga fotoszintetikus aktivitásának vizsgálata.................................................. 64

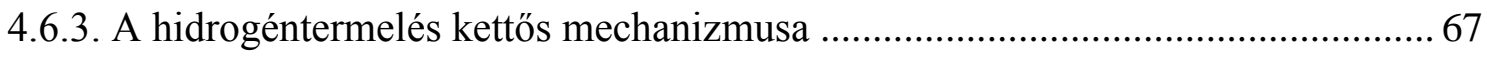

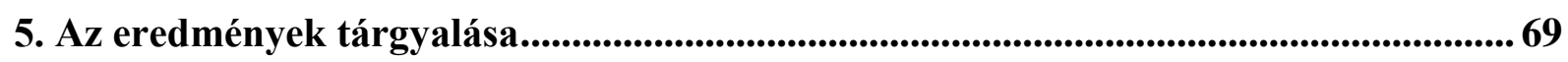

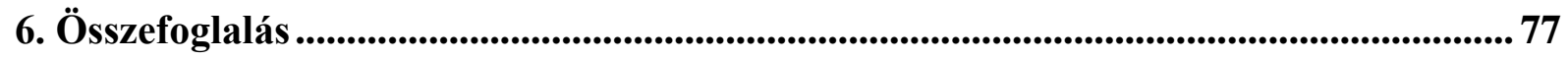

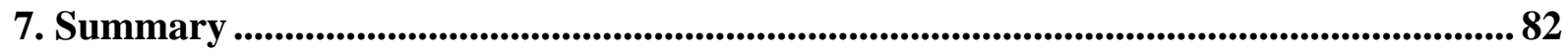

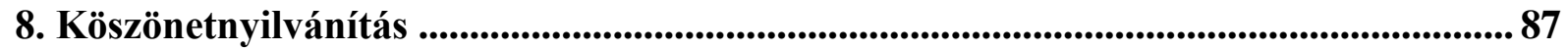

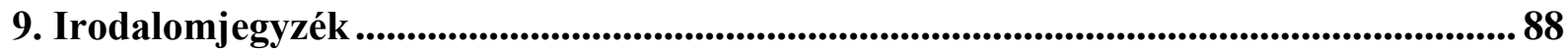




\section{Rövidítések jegyzéke}

acetil-CoA: acetil-koenzim A

ACK: acetát-kináz

ADH: alkohol-/aldehid-dehidrogenáz

ADHE: alkohol-dehidrogenáz, aldehid-dehidrogenáz aktivitás nélkül

ATP: adenozin-5'-trifoszfát

Chl: klorofill

$\mathbf{C N}^{-}$: cianid

DCMU: 3-[3,4-dichlorophenyl]-1,1-dimethylurea

GC: gázkormatográf

GTP: guanozin-trifoszfát

HPLC: nagy teljesítményü folyadékkromatográfia

kDa: kilodalton

LB: Luria Broth tápoldat

MACC: Mosonmagyaróvári Alga Kultúra Gyüjtemény

OD: optikai denzitás

OJIP: gyors klorofill a fluoreszcencia indukció

PAT: foszfo-transzacetiláz

PCR: polimeráz-láncreakció

PDC: piruvát-dekarboxiláz

PFL: piruvát-formát liáz

PFR: piruvát-ferredoxin oxidoreduktáz

ppmv: a térfogat milliomod része

PQ: plasztokinon

psi: font per négyzethüvelyk

PSI: I. fotokémiai rendszer

PSII: II. fotokémiai rendszer 
$\mathbf{Q}_{\mathrm{A}}$ és $\mathbf{Q}_{\mathrm{B}}$ : PSII elsődleges és másodlagos kinon akceptora

RT-PCR: reverz transzkripció kapcsolt polimeráz-láncreakció

TAP: Tris - Acetát - Foszfát

TP: Tris - Foszfát 


\section{Elöszó}

Az ipari forradalom kezdete óta, az iparosodó világunk egyre nagyobb mértékü energiaigénye miatt a fosszilis energiahordozók felhasználása egyre intenzívebben növekszik. Egy átlagos emberi test nyugalmi állapotban $0.1 \mathrm{~kW}$, míg munka közben $0.4 \mathrm{~kW}$ energiát fogyaszt naponta. Az ilyen alacsony szintü energiafogyasztásnak semmilyen káros hatása nincs az atmoszférára, mert a légzésünk során felszabadult többlet széndioxidot a növények képesek újrahasznosítani a fotoszintézisük során. Ha visszatekintünk az ipari forradalom előtti időszakra, akkor láthatjuk, hogy az emberek által használt korai technológiák a rendelkezésre álló víz- és szélenergiák felhasználásával, környezetszennyezés nélkül is képesek voltak a hatékony müködésre.

A gőzgép 1712-es felfedezésével az ember megalkotta az első olyan eszközt, amely képes volt a szénben rejlő energiát mechanikus munkává alakítani (Encyclopaedia Britannica 2001). A gőzgép felfedezésével elindult az iparosodás megállíthatatlan folyamata, amely alapjaiban változtatta meg a társadalom igényét az egyre nagyobb mértékü energiafelhasználás iránt. Kezdetben a gőzgép müködéséhez a szénben rejlő fosszilis energiát használták fel. Később, az újabb energiahordozók felfedezésével, a szén mellett a folyékony nyersolaj és a földgáz is egyre nagyobb szerepet kapott. Az újabb energiahordozók elterjedésével a felhasznált energiahordozókban az egy szénatomra jutó hidrogén atomok száma is folyamatosan emelkedett. A gazdasági és ipari fejlődés hatására az elmúlt két és fél évszázad során a világ energiafelhasználása drasztikus mértékben növekedett. Jelenleg az emberiség által felhasznált energia $80 \%$-a fosszilis energiahordozók elégetésén alapszik. Napjainkban, évente megközelítőleg $1.2 \times 10^{14} \mathrm{kWh}$ energiát használunk (Martin-Amouroux, 2003). Ez azt jelenti, hogy évente egy ember átlagosan $2 \mathrm{~kW}$ energiát használ fel. De fontos figyelembe venni azt a tényt is, hogy eközben jelenleg 2 milliárd ember egyáltalán nem használ fosszilis energiahordozókat. A fejlett országokban az egy före jutó energiafelhasználás jóval magasabb, az USA-ban $10 \mathrm{~kW}$, míg Európában $5 \mathrm{~kW}$ évente (International Energy Agency 2002). A jelenleg meglévő és az elöre felbecsült tartalékok fokozatos csökkenése, illetve a fejlődő országok folyamatosan növekvő energiaigénye miatt a piaci igényeket egyre nehezebben lehet kielégíteni. Mindez az egyes energiahordozókra nézve eltérő mértékü. A kitermelhető nyersolaj mennyisége például jelentősen rövidebb ideig lesz elegendő a jelenlegi felhasználás üteme mellett, mint a széné (Brazilian Political Science 
Review 2008). Viszont a legnagyobb probléma az, hogy bármeddig is tartanak ki ezek a források, a mennyiségük véges.

A fosszilis energiahordozók utáni igénynek szintén jelentős hatása van az egyes országok közötti szociális, politikai és gazdasági kapcsolatokra. Példának okáért a nyersolaj kétharmad része a közel keleti régióban található, de az ebből gyártott üzemanyag jelentős részét a fejlett nyugati államok használják fel. A vízi és szárazföldi úton nagy távolságokra történő nyersanyagszállításnak a környezetre nézve szintén hatalmas kockázatai vannak (Hall és mtsai. 2003). Az erőforrások ilyen formájú egyenlőtlen eloszlása az egyik legfőbb hajtóereje a nemzetközi politika instabilitásának, melynek eredménye a régiók közti gyakori háborúskodás és az egyre fenyegetőbb méreteket öltő terrorizmus.

A fosszilis energiahordozók elégetésével fokozatosan emelkedik a légtér széndioxid tartalma. Évente körülbelül 6 gigatonna gáz kerül a környezetünkbe. Az intenzív erdőirtások hatására egyre zsugorodó erdős régiók miatt a földet borító növények egyre kevésbé képesek a fotoszintézisük során abszorbeálni ezt a növekvő mennyiségü üvegházhatású gázt (Intergovernmental Panel on Climate Change 2006). A növények a fotoszintézisük során évente megközelítőleg $2 \times 10^{12} \mathrm{~kg}$ szenet képesek megkötni. Az óceánok élővilága szintén egy körülbelül ehhez hasonló mennyiséget képes évente felhasználni. Ezt figyelembe véve az emberi aktivitás hatására a széndioxid növekedése az atmoszférában évente körülbelül $3 \mathrm{x}$ $10^{12} \mathrm{~kg}$. Ez végső soron évenkénti $0.4 \%$-os növekedést jelent. Ennek a folyamatnak az eredményeként mára a légkörünk széndioxid koncentrációja átlépte a 350 ppm-es (egymillióra jutó részecske) határt. A koncentráció fokozatos emelkedésének a fő problémája az, hogy a széndioxid az üveghatású gázok közé tartozik és a mennyiségének növekedésével párhuzamosan fokozatosan növekszik Földünk átlaghőmérséklete is. A Föld légkörének átlaghőmérséklete sajnos azzal együtt emelkedik, hogy közben a naptevékenység intenzitása fokozatosan gyengül., pedig ebben az esetben az átlaghőmérsékletnek inkább csökkennie kellene.

A fosszilis energiahordozók negatív hatásai mellett a pozitív tulajdonságai közé tartozik, hogy jótékony hatással vannak az országok gazdasági fejlődésére és ezzel együtt a lakosság életszínvonalának növekedésére. Az országok átlagosan felhasznált energiamennyisége szoros összefüggésben áll az általuk termelt nemzeti össztermék értékével. Az olyan országokban ahol alacsony az energiafelhasználás, általában a nemzeti össztermékek is alacsony értékeket mutatnak. Viszont minél magasabb egy ország 
energiafogyasztása, annál magasabb a nemzeti össztermékének értéke. Ezért a világ iparosodott országainak egyik legfőbb gazdasági célja, hogy minél nagyobb részt szerezzenek meg a Földön rendelkezésre álló fosszilis energiaforrásokból.

Mindezek a problémák egyre inkább arra sarkallják az emberiséget, hogy olyan új, tiszta és megújuló alternatív energiaforrások és energiahordozók után kutassanak, amelyek képesek kielégíteni a jövő nemzedékeinek növekvő energiaszükségleteit. Az elérhető alternatív és környezetbarát energiahordozók felfuttatása mellett egy másik fontos cél, hogy az energiaforrások előállítási helyei is diverzifikálódjanak. Az energiatermelés delokalizálásának útján lehetővé válhat az országok energiabiztonságának javulása, a régiók közti ellentétek csökkentése és az energiafelhasználás hatékonyságának növekedése (Nouni 2012). 


\section{Bevezetés}

\subsection{A hidrogén jelene és jövője}

Habár a hidrogén az egyik legközönségesebb elem a Földön, elemi formában nagy mennyiségben nem fordul elö. A hidrogén egy olyan tiszta és alternatív energiahordozó, amely a jövőben a fosszilis energiahordozók helyettesítése nyomán kiemelkedő szerepet játszhat az üvegházhatású gázok kibocsátásának csökkentésében (Christopher és Dimitrios 2012). A hidrogén elégése során csupán víz keletkezik, ami messzemenően eleget tesz a tiszta és szénmentes energiahordozókkal szemben állított követelményeknek. A benne található kémiai energia mennyisége alapján is kiváló energiahordozónak tekinthető, mivel $122 \mathrm{~kJ} / \mathrm{g}$ energiát képes tárolni, amely a szénhidrogén alapú üzemanyagokéhoz hasonlítva 2.75-ször nagyobb. Mindezek alapján a hidrogén a jövő egy ígéretes energiahordozó jelöltje lehet, mivel nem csak jó hatásfokkal szabadítható fel a benne tárolt energia, hanem egyben alacsony a káros anyag kibocsátása és magas az energiasürüsége is.

John Bockris már 1970-ben felvetette egy a hidrogénre épülő gazdasági modell ötletét, amelyben egy olyan hálózati rendszert vázolt fel, ahol az energiaellátás alapját a hidrogén képezi (Bockris 1975). A hálózatos rendszer kiépítésének egy lényeges eleme, hogy elősegítse a hidrogén széleskörü felhasználásának az elterjedését, ezáltal hozzájárulva a szénhidrogének alkalmazásából adódó problémák negatív hatásainak csökkentéséhez. Összehasonlítva a különböző energiarendszereket, a hidrogén mutatkozik az egyik legjobbnak az ismert energiahordozók közül. A hasznosíthatósága szempontjából sokkal inkább hasonlít az elektromossághoz, mint a fosszilis üzemanyagokhoz (Lipman 2011). Nem csak a szállítási célokra való felhasználása miatt tartozik a legígéretesebb tüzelőanyagok közé, hanem a lokális célú felhasználás szemszögéből is. A magas elektrokémiai reakcióképessége miatt a belső égésű motorok mellett jól alkalmazható az üzemanyag cellákban is a megfelelő katalizátor használata mellett.

Felhasználását tekintve a gazdaságban jelenleg olajfinomításra, élelmiszerek előállítására, fémek megmunkálására és mütrágya előállítására használják (Lipman 2011). Felhasználása a kémiai folyamatok katalizálásában, a kőolaj kinyerésében és finomításában, fémek kinyerésében és kialakításában, az ürtechnológiában és az üzemanyag cellák használatában a leginkább megalapozott. Ezek mellett még felhasználható redukáló ágensként, védőgázként, élelmiszer adalékanyagként és rotor hütőanyagként. Jelenleg a legnagyobb igény a hidrogénre az olajfinomításban és az ammóniagyártásban jelentkezik 
(Markets and Markets 2011). Komoly potenciálja lehet a jövőben szállítójármüvek üzemanyagként, valamint az erőmüvekhez müködéséhez szükséges energiahordozóként. A globális hidrogéntermelés piacának méretét 2010-ben 53 millió metrikus tonnára becsülték, míg a piacai értékét 82,6 milliárd dollárra tartották (Markets and Markets 2011). A globális hidrogéntermelés növekedésének mértékét úgy becsülik, hogy az üzemanyagok kéntartalmának csökkentése, a csökkenő nyersolaj minősége és a növekvő számú üzemanyagcellák hidrogén igénye miatt, 2011 és 2016 között évente átlagosan 5,6 \%-kal fog nőni. Jelenleg a 39 \%-os globális termelésükkel és a 21 millió metrikus tonna éves előállítási mennyiségükkel az ázsiai és óceániai régiók tekinthetők a legnagyobb piacoknak (Markets and Markets 2011).

A hidrogén ipari előállításának legfőbb forrásai a fosszilis tüzelőanyagok, például a földgáz vagy a metán, amelyekből gőzreformálással állítható elő a hidrogén. A szénhidrogének felhasználásával helyettesíthető a magas energiaszükségletü hidrolízisen alapuló vízbontás. Mindezek mellett még jelentős mennyiség származik az ipari folyamatok során melléktermékként visszamaradt hidrogénből. Az globális hidrogénelőállítás jelenleg túllépi a napi 1 milliárd köbméter mennyiséget, amelynek $48 \%$-át földgázból, $30 \%$-át nyersolajból, 18 \%-át szénből és a fennmaradó 4 \%-ot víz elektrolízisével termelik. A gőzreformálás mellett nagy tisztaságú hidrogén állítható elő a víz-gáz eltolás módszerével, amelynek fontos szerepe az ipari ammóniaszintézis folyamatában van. Az ipari előállítás módszereit tekintve a földgáz gőzreformálása után a második helyen a szén, a nehéz olajok és más alacsony értékü finomított termékek részleges oxidációja áll (Lipman 2011; Markets and Markets 2011). Végül harmadik legelterjedtebb előállítási technológia pedig a szén elgázosításának módszere. A termokémiai úton hidrogén előállítására alkalmas technológiák még az autoterm reformálás, a katalitikus parciális oxidáció, a termális lebontás, a gázosítás és a pirolízis (Chen és Syu 2010). A fosszilis energiahordozók felhasználásán alapuló hidrogéntermelés velejárója az üvegházhatású gázok kibocsátása, amely a hidrogén számos előnye mellett komoly terhet jelent környezetünk számára. Emiatt napjainkban a módszer megújuló természetének köszönhetően egyre növekvő figyelmet kap a biomasszából és hulladékból biológiai úton előállítható biohidrogén.

Az energiakrízis lehetősége, a klímaváltozás problémája, a magas olajárak és az egyre csökkenő fosszilis energiaforrások komoly globális figyelmet biztosítanak az alternatív, megújuló, széndioxid-kibocsátás mentes és környezetbarát biológiai eredetű üzemanyagok előállításának. A bioenergia alkalmazása izgalmas és megújuló alternatívát nyújt a fosszilis tüzelőanyagok kiváltására. A bioenergia elterjedése lehetővé teheti számunkra az 
energiaforrások diverzifikálását és az energiaellátás kockázatainak csökkentését. Emellett lehetőséget adhat még a vidéki családi gazdaságok fejlődésére és megerősödésére (International Energy Agency 2008). A fotoszintetikus baktériumok, a cianobaktériumok és a zöldalgák olyan rugalmas és változatos metabolikus útvonalakkal rendelkező mikroorganizmusok, amelyek képesek átalakítani különböző szerves anyagokat bioenergiává (Pandey és mtsai. 2013, Xuefeng 2014). Az eddigi ígéretes eredmények alapján jelenleg szerte a világban széleskörü és mélyreható kutatások folynak a megújuló energiaforrásokból való bioenergia elöállítására. A hidrogéngazdaság által nyújtott inspiráló jövőkép alapján feltételezzük, hogy a mikroorganizmusok által előállított bioenergia a számos pozitív tulajdonsága miatt egyre nagyobb szerephez fog jutni a jövőben.

\subsection{Biohidrogéntermelő algák}

Az algák nem alkotnak önálló rendszertani egységet, prokarióta és eukarióta divíziói is vannak. Felépítésük rendkívül változatos. A kék-algák vagy kék-zöld algák képviselik a prokarióta divíziót, helyes rendszertani elnevezésük a cianobaktériumok. Az eukarióta algák legösszetettebb morfológiával rendelkező típusai a hínárokhoz hasonlóak. Az algák többsége fotoszintetizál és oxigént termel, ezáltal jelentős szerepet játszanak a globális széndioxid felhasználásában és oxigéntermelésben. Elterjedésüket tekintve is rendkívül változatosak, édes és sós vizekben, jégfelületen, hőforrásokban, sziklák legfelső rétegében és a talajban is megtalálhatóak. Metabolikus kapacitásuk is rendkívül változatos, ez teszi lehetővé, hogy több különböző energiahordozó alapanyagának előállítására is alkalmasak, többek között hidrogenázaikkal biohidrogént is képesek előállítani (Razeghifard 2013). Két nagyobb alga csoport, az eukarióta zöldalgák és a prokarióta cianobaktériumok bizonyos tagjai képesek hidrogén elöállításra (Ghirardi 2007).

A cianobaktériumok a Föld legősibb szervezetei közé tartoznak. Sejtjeik felépítése megegyezik a baktériumokéval, de ostoros formáik nem ismertek. Plazmájuk az örökítő anyagot tartalmazó belső, színtelen centroplazmára és a fotoszintetikus pigmenteket tároló külső kromatoplazmára tagolódik. A kromatoplazmában a sejt felszínével párhuzamosan a tilakoid membránok húzódnak, amelyekben klorofill-a, karotinoidok, valamint a felszínükön található fikobiliszómákban fikobilin festékek kötik meg a napfény energiáját. A fikobilinek közül a kék fikociánt minden faj tartalmazza, a vörös fikoeritrin gyakran hiányzik. A cianobaktériumok hidrogenázai minden esetben NiFe hidrogenázok, egyik típusuk kizárólag a 
hidrogén felvételére (Hup-típusú, Hydrogen uptake enzimek), míg a másik cianobaktériumokban előforduló típus a hidrogén felvételére és kibocsájtására is képes (kétirányú, Hox-típusú enzimek) (Ghirardi 2007).

A Chlorophyta a valódi eukarióta zöldalgák divíziója. Általánosan jellemző rájuk, hogy klorofill a-t és klorofill b-t tartalmaznak. Tartalék tápanyagként keményítőt halmoznak fel a plasztidjaikban. Egysejtü és többsejtű formáik is vannak. A legtöbb faj édesvízben vagy tengerekben él, megtalálhatóak a legkülönbözőbb szárazföldi, de akár szélsőséges élőhelyeken is. Az ide tartozó fajokra (pl. Chlorella fusca (Winkler és mtsai. 2002), Scenedesmus obliquus (Florin és mtsai. 2001) és Chlamydomonas reinhardtii (Ch. reinhardtii) (Happe és Kaminski 2002)) jellemző, hogy FeFe hidrogenázokat tartalmaznak és megfelelő környezeti adottságok mellett mind biohidrogén előállítására, mind a megtermelt hidrogén felhasználására is képesek.

\subsection{A biológiai hidrogéntermelés lehetőségei}

\subsubsection{A biohidrogéntermelés általános jellemzése}

1939-ben Hans Gaffron megfigyelte, hogy egy tipikus zöldalga (Ch. reinhardtii), amely normális körülmények között tavakban él, alkalmanként képes az oxigéntermelésről hidrogéntermelésre váltani, amelynek termékét ma biohidrogénnek nevezzük. A biohidrogén egy természetes és átmeneti mellékterméke a különböző mikroorganizmusok biokémiai reakcióinak. A biológiai úton történő hidrogéntermelés nagyrészt környezeti hőmérsékleten és nyomáson megy végbe, ezért a kémiai és elektrokémiai módszerekhez viszonyítva kevésbé energiaigényes folyamat. A természetben előforduló hidrogén metabolizmus elsődlegesen az archeákra, baktériumokra és a mikroalgákra jellemző. A taxonómiailag elkülönülő csoportok számos különböző biohidrogéntermelésre képes fajt foglalnak magukba. Emellett a mikroorganizmusokat a bennük található hidrogéntermeléshez köthető különböző enzimek, valamint eltérő metabolikus útvonalak alapján szintén csoportokra oszthatjuk. (Vignais és mtsai. 2001; Weaver és mtsai. 1980). A biológiai hidrogéntermelő folyamatok fehérjéi a hidrogenáz és nitrogenáz enzimek. Ezek az enzimek játsszák a kulcsszerepet a prokarióták és néhány eukarióta organizmus hidrogén-metabolizmusában. Az algákhoz köthető jelenlegi hidrogéntermelési fejlesztések leginkább a biofotolízisre és a fotoszintetikus hidrogéntermelésre irányulnak. A fotoszintetikus mikroorganizmusok hidrogéntermeléséhez a 
napfény elengedhetetlenül szükséges. A fotoautrotróf zöld mikroalgák és cianobaktériumok a széndioxidot és a napfényt képesek egyedüli szén és energiaforrásként felhasználni. A víz oxidációjához szükséges fotoszintetikus és biofotolitikus redukáló erők a megvilágításból származnak (Ghirardi és mtsai. 2000; Schütz és mtsai. 2004). A biológiai hidrogéntermelést fényfüggése alapján a fényfüggetlen sötét fermentációs és a fényfüggő fotoszintetikus folyamatokra oszthatjuk. A szénforrás és az alkalmazott biokatalitikus folyamatok alapján a biohidrogéntermelést szintén fotoszintetikus és fermentatív folyamatokra oszthatjuk. A cianobaktériumok direkt vagy indirekt fotolízissel, míg a zöldalgák a direkt és indirekt fotolízis mellett sötét fermentációval is képesek a hidrogéntermelésre (Kovács és mtsai. 2006; Sen és mtsai. 2008).

\subsubsection{A hidrogenázok csoportjai és tulajdonságai}

A hidrogenázok olyan enzimek, amelyek képesek katalizálni a molekuláris hidrogén oxidációját a következő egyenletek alapján: $\mathrm{H}_{2}+\mathrm{A}_{\mathrm{ox}} \rightarrow 2 \mathrm{H}^{+}+\mathrm{A}_{\text {red }}$ és $2 \mathrm{H}^{+}+\mathrm{D}_{\text {red }} \rightarrow \mathrm{H}_{2}+\mathrm{D}_{\mathrm{ox}}$ A hidrogén felvételekor az elektron akceptorok redukálódnak. Ennek során elektron akceptorként szolgálhat az oxigén, a nitrát, a szulfát, a széndioxid és a fumarát. A hidrogéntermelés során a protonok úgy redukálódnak, hogy elektron donorokat, például ferredoxint (FNR), citokróm c3-at és c6-ot oxidálnak.

A hidrogenázok az aktív centrumuk fématom tartalma alapján három különböző csoportra oszthatóak: NiFe (nikkel-vas), FeFe (vas-vas) hidrogenázok, amelyek vas-kén klasztert (FeS klaszter) tartalmaznak és a FeS klasztert nem tartalmazó, hidrogéntermelő metilén-tetrahidrometanopterin dehidrogenáz (Hmd) enzimek. Ez a három, filogenetikailag is különböző csoport közös tulajdonsága, hogy rendelkeznek egy funkcionális alapegységgel, mely az adott csoportban konzervált. Ez az alapegység az egyes fehérje alegységeket vagy doméneket jelenti, melyek az aktív centrumot tartalmazzák, és az enzimek ezen alapegysége nélkülözhetetlen a müködéséhez (Vignais és mtsai., 2001, Vignais és mtsai., 2007). Az aktív centrumok fématomjaihoz szénmonoxid $(\mathrm{CO})$ és cianid $\left(\mathrm{CN}^{-}\right)$ligandok kapcsolódnak (Fontecilla-Camps és mtsai. 2007).

Hmd hidrogenázokat először a Methanothermobacter marburgenis-ben írták le (Zirngibl és mtsai. 1992, Thauer és mtsai. 1996). Jellemező rájuk, hogy nem tartalmaznak sem nikkelt, sem FeS klasztert. Az enzim alacsony nikkel tartalmú tápon nevelt sejtekben indukálódik (Afting és mtsai. 1998). Az enzim homodimer formájú, két 38 kDa-os 
alegységből áll és egy Fe tartalmú specifikus kofaktort köt. A NiFe és FeFe hidrogenázokkal ellentétben a Hmd hidrogenázok nem katalizálják a $\mathrm{H}_{2} \leftrightarrow 2 \mathrm{H}^{+}+2 \mathrm{e}^{-}$reakciót. Viszont részt vesznek a sejt metanogenezisében, ahol az N5,N10-metenil-tetrahidrometanopterin $\mathrm{H}_{2}$-nel való reverzibilis reakcióját katalizálják, miközben N5,N10-metilén-tetrahidrometanopterin és $\mathrm{H}^{+}$keletkezik (Hartmann és mtsai. 1996).

A NiFe hidrogenázok katalitikusan fontos magja alapvetően egy $\alpha$ és egy $\beta$ alegységből álló heterodimer. A kb. 60 kDa-os nagy alegységben (az $\alpha$-alegység) található a két fématomot tartalmazó aktív centrum, míg a kis alegység ( $\beta$ alegység) nagyjából 30 kDa nagyságú, mely az enzim aktív centruma és a megfelelő elektrondonor/akceptor közötti elektrontranszferért felelős FeS kockákat tartalmazza. Előfordulhatnak a periplazmában, a citoplazmában és kötődhetnek a citoplazma membránjához egyaránt. A hidrogénelőállítást és a felvételt is képesek katalizálni a citokrómok oxidált állapotától függően (Vignais és mtsai. 2007). A nagy alegység belsejében Ni és Fe ionok találhatóak, amelyek négy cisztein révén kapcsolódnak a fehérjéhez. A Fe ionhoz nem fehérjetermészetű ligandumok, például CO és $\mathrm{CN}^{-}$ligandumok is kapcsolódnak (Happe és mtsai. 1997, Pierik és mtsai. 1999, Volbeda és mtsai. 2002). A kis és nagy alegység szekvenciaanalízise alapján a NiFe hidrogenázokat négy csoportba sorolják, melyek összhangban állnak az enzimek fiziológiás funkcióival (Vignais és mtsai. 2001):

- hidrogénfelvevő NiFe hidrogenázok

- citoplazmatikus $\mathrm{H}_{2}$ szenzor és cianobakteriális típusú hidrogénfelvevő NiFe hidrogenázok

- kétirányú, heteromultimer, citoplazmatikus NiFe hidrogenázok

- több alegységes, hidrogéntermelő, energiakonzerváló, membránkötött hidrogenázok

A NiFe hidrogenázok éréséhez összeszerelő fehérjék szükségesek. A NiFe hidrogenázok bioszintézis vizsgálatainak egyik leginkább tanulmányozott modellje az E. coli 3-as hidrogenáza. A folyamatban résztvevő legfontosabb fehérjék a hidrogenáz pleiotróp, azaz Hyp fehérjék (HypA, HypB, HypC, HypD, HypE, HypF) és az adott enzimre specifikus endopeptidázok. A hidrogenázok érési folyamatának a végén a kis és nagy alegységek oligomerizálódnak.

FeFe hidrogenázokat elsősorban anaerob prokariótákban és néhány aerob eukariótában találhatunk (Boichenko és mtsai. 2004, Vignais és mtsai. 2001). A FeFe hidrogenázok tartalmaznak egy 2 fématomból álló centrumot, amelyhez ditiolát kofaktor kapcsolódik (Berggren és mtsai. 2013). A NiFe hidrogenázokhoz viszonyítva, a FeFe hidrogenázok 
szignifikánsan nagyobb hatékonysággal képesek hidrogéntermelésre, viszont az oxigén jelenlétére is érzékenyebbek. Szerkezetük alapján lehetnek mono-, di-, tri-, vagy tetramerek (Vignais és mtsai. 2001). A kb. 350 aminosavból álló konzervált domén (más néven Hklaszter) tartalmazza az aktív centrumot, mely a fémionok közül csak Fe ionokat tartalmaz, valamint [4Fe4S] klasztert, amely cisztein aminosavakon keresztül kapcsolódik a fémcentrumhoz és a fehérjemátrixhoz. Az aktív centrum Fe ionjaihoz nem fehérjetermészetü, $\mathrm{CN}^{-}$, és CO ligandok is kapcsolódnak (Peters és mtsai. 1998, Nicolet és mtsai. 1999, Peters 1999). Ezekben a hidrogenázokban az elektronok a ferredoxin molekulákon keresztül közvetlenül a H-klaszterre szállítódnak.

Az első Fe hidrogenázt a Scenedesmus obliquus-ban (Florin és mtsai. 2001) írták le. Mára részletesen karakterizálták a Ch. reinhardtii HydA1 (Happe és Kaminski 2002) és HydA2 (Forestier és mtsai. 2003), a Chlorella fusca (Winkler és mtsai. 2002) és a Chlamydomonas moewusii (Winkler és mtsai. 2004) FeFe hidrogenázait is. A hidrogenázok működéséhez összeszerelő fehérjék szükségesek, a FeFe hidrogenázok is érési folyamaton mennek keresztül. Ezeket először Ch. reinhardtii-ban fedezték fel (Posewitz és mtsai. 2004). Két fehérje vesz részt az algák Fe hidrogenázainak bioszintézisében, a HydEF és a HydG összeszerelő fehérjék. A HydEF egy dimer fehérje, amelynek $S$-adenozilmetionin hasító és GTP hidrolizáló aktivitása van. A HydG fehérje kizárólag $S$-adenozilmetionin hasító aktivitással bír (Rubach és mtsai. 2005).

\subsubsection{A fotoszintetikus hidrogéntermelés}

A hidrogén előállítása során a fotoszintetikus apparátus segítségével a fényenergia biokémiai energiává alakítható (Jordan és mtsai. 2001). Ebben a módszerben jelentős potenciál rejlik a megújuló energiák jövőbeni előállítása szempontjából. A hidrogéntermelés fotoszintetikus mechanizmusát már a korai 1940-es évektől ismerik (Gaffron és Rubin 1942). A fotoszintetikus mikrobiális közösségek már a Föld kémiai evolúciójának alakulásában is fontos szerepet játszottak (Burow és mtsai. 2011). A hidrogéntermelő mikroorganizmusokat taxonómiájuk alapján három fő fiziológiailag különböző csoportra oszthatjuk. Ide tartoznak a különböző egysejtü zöldalgák (Gaffron és Rubin 1942), a cianobaktériumok és a fotoszintetikus baktériumok (Gest és Kamen 1949). A hidrogéntermelő fotoszintetikus mechanizmus aerob és anaerob környezetben egyaránt müködhet, de a hidrogén előállításának módja alapjaiban különbözik a két folyamatnál (Beer és mtsai. 2009; Kruse és Hankamer 
2010; Kruse és mtsai. 2005). Zöldalgákban és cianobaktériumokban a fény a II. fotokémiai rendszernek (PSII) meghajtó forrásaként szolgál az oxidáló ágensek előállításához. A fény energiája képes oxidálni a vizet elektronra, protonra és oxigénre a direkt fotolízis útján (Allakhverdiev és mtsai. 2010; Doebbe és mtsai. 2010; Krassen és mtsai. 2009). Mindkét esetben a FeFe hidrogenáz számára a redukált ferredoxin szolgáltat elektron donorokat. A redukáló erők az egyes típusú fotoszintetikus rendszer klorofill- $\alpha$ a dimerjére szállítódnak. A P700-at a fény abszorbciója gerjeszti, melynek hatására az elektronpotenciál -1.32 V-ra emelkedik (Krabben és mtsai. 2000). Végül az elektronok a I. fotokémiai rendszer akceptor oldalán található FeS csoportokhoz áramlanak a belső elektrontranszportláncon keresztül és 0.45 V-ra változtatják annak elektromos potenciálját (Jordan és mtsai. 1998). A hidrogenázok aktivitása a redukáló ágensek mennyiségén alapszik, amelyek származhatnak direkt úton a közvetlen fotoszintetikus vízbontásból vagy indirekt módon a szerves molekulák lebontásából.

\subsubsection{Direkt fotolízis}

A direkt fotolízis során a mikroalgák és a cianobaktériumok arra használják fel a fotoszintetikus képességüket, hogy a vizet közvetlenül oxigénre és hidrogénre bontsák. A cianobaktériumok, más néven kék-zöld algák, azon baktériumok törzsébe tartoznak, amelyek a fotoszintézisen keresztül nyerik az energiát. A mikroalgák rendelkeznek azzal a képességgel, hogy a fény energiájával a vizet vízbontás útján protonokra és elektronokra tudják bontani. A biohidrogén termelés a fény direkt abszorpcióján és az elektronok hidrogenázok és nitrogenázok felé történő szállításán keresztül megy végbe (Manish és Banerjee 2008). Anaerob körülmények között, vagy amikor az erős fénysugárzás hatására a fotoszintetikus rendszer erősen redukált állapotba kerül, néhány mikroorganizmus a fölösleges elektronokat hidrogenáz enzimekkel távolítja el, úgy hogy a hidrogén ionokból hidrogén gázt fejleszt (Sorensen 2005; Turner és mtsai. 2008). A vizsgálatok szerint a hidrogenázok által a protonokból és elektronokból előállított hidrogén gáz tisztasága megfelelő körülmények mellett elérheti akár a 98 \%-ot is (Hankamer és mtsai. 2007).

Az elektronok az algák és a cianobaktériumok tilakoid membránjában található II. fotokémiai rendszerének vízbontásából származnak. A II. fotokémiai rendszer a napból származó fotonokat használja fel az elektronok aktiválásához, hogy azok átjussanak a tilakoid membrán elektrontranszport láncán, az I. fotokémiai (PSI) rendszeren és a ferredoxinon 
keresztül egészen a hidrogenázig (Florin és mtsai. 2001). A plasztokinon molekulát az elektron plasztokinollá alakítja, amely vagy a NADP+ -t NADPH-vá redukálja vagy ciklikus elektrontranszportban használódik fel. Az elektronok helyébe ismét víz lép, hogy a II. fotokémiai rendszer vízbontó centruma hidrogénionokat és molekuláris oxigént hozzon létre, ezáltal szolgáltatva ionokat a fotoszintézis számára. A víz oxidációja során keletkező protonok létrehoznak egy proton grádienst, amelyet az ATP szintáz ATP termeléshez használ fel. A ferredoxin-NADP ${ }^{+}$reduktáz a fotoszintetikusan előállított elektronokat és a sztrómába juttot protonokat felhasználva NADP ${ }^{+}$-ból NADPH-t állít elő. A folyamat a hidrogén és az oxigén párhuzamos termelését eredményezi (Spruit 1958; Greenbaum és mtsai. 1983).

\subsubsection{Indirekt fotolízis}

A direkt fotolízisen kívül fotoszintetikus úton hidrogén állítható elő zöldalgákkal úgy, hogy a folyamat során kénmegvonást alkalmazunk (Melis és mtsai. 2000, Manish és Banerjee 2008). A kénmegvonás a biohidrogéntermelés egy olyan módszere, amellyel kiküszöbölhető az alga hidrogenázainak oxigénérzékenysége és megvalósítható az akár négy-öt napon át tartó folyamatos hidrogéntermelés (Melis és mtsai. 2000). Ez a megközelítés lehetőséget ad arra, hogy az algával jelentős mennyiségü hidrogént tudjunk megtermelni (Happe és mtsai. 2002; Melis és mtsai. 2004, 2007; Ghirardi 2006; Seibert 2008). A kénmegvonás az algakultúrák oxigéntermelésének részleges és visszafordítható gátlását eredményezi. Kén hiányában a csökkent metabolikus aktivitás mellett az alga csak olyan fehérjéket szintetizál, amelyek elengedhetetlenül szükségesek a sejtek életben maradásához (Wykoff és mtsai. 1998). A módszer eredményeként a II. fotokémiai rendszer D1 fehérjéje a lebomlása után nem tud gyorsan felépülni, emiatt fokozatosan csökken az oxigéntermelése. Ezzel párhuzamosan a tápanyaghiány által okozott stresszre válaszként az alga 8 -20-szor több keményítőt halmoz fel, mint normál körülmények között (Tsygankov és mtsai. 2002; Zhang és mtsai. 2002). Az oxigéntermelés csökkenése és a sejtlégzés változatlan aktivitása miatt az oxigén szintje fokozatosan redukálódik, a zárt kultúra egy idő után anaerobbá válik (Antal és mtsai. 2003). Az anaerob körülmények kialakulása a kultúrában számos különböző folyamatot indít be (Melis és Happe 2001). A HydA1 és HydA2 gének aktiválódnak, majd 3-4 óra elteltével a hozzájuk tartozó funkcionális fehérjék detektálhatóvá válnak (Forestier és mtsai. 2003). A hidrogén körülbelül 5 óra elteltével válik mérhetővé (Antal és mtsai. 2003). A kezdeti keményítő felhalmozás abbamarad és megindul a lebontási folyamat, melynek eredményeként 
a hidrogéntermeléshez szükséges redukáló ágensek felhalmozódnak. A felhalmozott keményítő először piruváttá bomlik, amelyböl később acetát, formát vagy néhány esetben etanol képződik (Tsygankov és mtsai. 2002; Zhang és mtsai. 2002; Happe és mtsai. 2002; Kosourov és mtsai. 2003; Winkler és mtsai. 2002b). A keményítő kiemelkedő szerepét a kénmegvonással stresszelt, Rubisco nélküli mutáns törzs csökkent hidrogéntermelése is bizonyítja (White és Melis 2006). Az anaerob körülmények ellenére a széndioxid fixálás nem müködik, mivel a Rubisco aktivitásának csökkenése már a kénmegvonás elején megindul (Melis és mtsai. 2000; Zhang és mtsai. 2002).

A kénmegvonás útján történő hidrogéntermelést megelőzi egy a levegőn, TAP (trisacetát-foszfát) tápoldaton, fotoheterotróf módon zajló biomassza növesztés, majd ezt követi egy tápoldat csere után a kénmentes TAP tápoldatban végbemenő hidrogéntermelés. A múltban számos sikertelen kísérletet végeztek fotoautrotróf körülmények között hidrogéntermelés céljából. Anaerob körülményeket és hidrogéntermelést csak a II. fotokémiai rendszer aktivitását gátló DCMU-val sikerült elérni fotoautrotróf körülmények között (Fouchard és mtsai. 2005). A zárt üvegben, kénmentes tápoldatban, fotoautrotróf körülmények között inkubált Platymonas subcordiformis csak kis mértékben termelt hidrogént, majd szénforrás hozzáadása után a termelés intenzitása 40\%-kal megnövekedett. A fotoautrotróf körülmények között tartott Chlamydomonas kultúra ecetsav helyett széndioxid hozzáadása mellett a kénmegvonás kezdeti fázisában képes volt hidrogéntermelésre. Viszont a hidrogéntermelés mértéke és a teljes felhalmozódott hidrogén mennyisége még így is elmaradt azoktól a korábban leírt adatoktól, ahol acetátot is alkalmaztak (Tsygankov és mtsai. 2006).

A hidrogéntermelés a kénmegvonás negyedik-ötödik napja után abbamarad, valószínüleg a kénmegvonás metabolizmusra gyakorolt általános negatív hatása miatt. A hidrogéntermelés ideje ugyanakkor megnövelhető, ha megfelelő időközönként változtatjuk a kén elvételét és hozzáadását (Ghirardi és mtsai. 2000), vagy időben elválasztjuk az oxigént a hidrogéntermelő fázistól (Fedorov és mtsai. 2005). Az előző megoldás egy olyan kettős fotobioreaktor rendszeren alapszik, ahol a kultúra először limitált mennyiségü szulfát mellett fotoszintetikus úton nő fel, majd a növesztés után a második fotobioreaktorban kezdi meg a hidrogéntermelést. Ebben az esetben a második fotobioreaktorban a sejteket rendszeresen pótolni kell az első fotobioreaktorból frissekkel. A rendszer körülbelül 6 hónapon keresztül képes így müködni, igaz az alacsony sejtkoncentráció miatt csak limitált szintü hidrogéntermelés mellett. 
A zöldalgák maximális elméleti fényátalakítás hatékonysága 10-13\% körülire becsült (Ghirardi 2006). Mivel ez a Napból származó erős megvilágítás során a fotoszintézis elektrontranszfer reakciója által korlátozott, ezért a 10-13\%-os szint csak kisméretü antenna fehérjéket tartalmazó mutáns törzsekkel érhető el (Melis és mtsai. 1998). A kénmegvonás alatt álló kultúrákban a fényátalakítás hatékonysága limitált fényerősség mellett feltehetően körülbelül 1\%-ra csökken, mivel a ként tartalmazó kultúrák fotoszintetikus kapacitása csak 10\% körül mozog (Melis és mtsai. 2000). A kereskedelmi hasznosításhoz szükséges hatékonyságról a vélemények megoszlanak. Az elérni kívánt hatékonysági szintet nagyban befolyásolja a hidrogén előállítási költsége. A vad típusú kultúrák maximális hatékonyságát 0.24 \%-ra becsülik, az alacsony sejtsűrüségü kultúrák miatt (Ghirardi 2006). A sejtkultúrák inert mátrixon, például üvegszálon való immobilizálásával sikerült elérni a kultúrák denzitásának növekedését kénmentes körülmények között, ezáltal egyszerüsítve a ként tartalmazó és kénmentes tápoldatok cseréjét és emelve alacsony fényintenzitás mellett a konverziós hatékonyságot 0.36 \%-ra (Laurinavichene és mtsai. 2006; Ghirardi 2006).

\subsubsection{Sötét fermentáció Chlamydomonas törzsekben}

A hidrogenáz aktivitás mind sötétben mind fényen a Chlamydomonas fermentatív metabolizmusának egy komponense. A rendelkezésünkre álló genomszekvenciák és publikációk alapján világosan látszik, hogy a Chlamydomonas számos olyan fehérjét kódol, amelyekhez különféle anoxikus útvonalak kapcsolódnak. (Hemschemeier és Happe 2005; Atteai és mtsai. 2006; Mus és mtsai. 2007). Amikor a Chlamydomonas törzs alacsony fényerősségű vagy sötét és limitált levegőzésű környezetben van, akkor a sejtlégzés során elhasznált oxigén mennyisége túllépheti a fotoszintézis során termelt oxigén mennyiséget, amely végeredményben hipoxiához vezet (Moseley és mtsai. 2000; Quinn és mtsai. 2002). A glikolízis központi metabolitja a piruvát. A Chlamydomonas genom az anaerob piruvát metabolizmushoz szükséges legtöbb útvonal minden egyes enzimét kódolja. Ez a metabolikus változatosság ritka egyetlen organizmusban, és a metabolizmusa szempontjából kiváló alkalmazkodó képességekkel ruházza fel az algát a különböző és dinamikusan változó környezeti feltételekhez, beleértve a hipoxiát is.

A Chlamydomonas a piruvátot feltételezhetően fermentatív körülmények között alakítja át a piruvát-formát liáz (PFL) útvonalon acetil-CoA-vá és formáttá, a ferredoxin redukálásával a piruvát-ferredoxin oxidoreduktáz 1 (PFR1) útvonalon acetil-CoA-vá és 
széndioxiddá; a putatív dekarboxiláz útvonalon acetaldehiddé és széndioxiddá, vagy a laktát dehidrogenázon keresztül a NADH oxidációjával laktáttá. A piruvát-ferredoxin oxidoreduktáz által redukált ferredoxin ezután különböző redox fehérjék által képes oxidálódni, beleértve a FeFe hidrogenázt, így termelhet a keményítő lebontása során hidrogént. A piruvát-ferredoxin oxidoreduktáz és a piruvát-formát liáz útvonalak együttes jelenléte egyedülálló jelenség az eukarióták körében, ami jól mutatja a Chlamydomonas metabolikus diverzitását. A piruvátformát liáz fehérjét sikerült kimutatni a kloroplasztban és a mitokondriumban egyaránt (Atteia és mtsai. 2006).

Az acetil-CoA a piruvát-formát liáz és a piruvát-ferredoxin oxidoreduktáz útvonalak terméke, amely a foszfo-transzacetiláz és acetát-kináz útvonalakon keresztül acetáttá alakul, ATP végterméket eredményezve. A Chlamydomonas-nak két génje van, amely mindezen fehérjéket kódolja. A foszfo-transzacetiláz 1 (PAT1) és az acetát-kináz 2 (ACK2) fehérjék a mitokondriumban találhatóak, míg a foszfo-transzacetiláz 2 (PAT2) és az acetát-kináz 1 (ACK1), amelyek génjei a HydA2 kódoló szekvenciáival határosak a kloroplasztban találhatóak (Atteia és mtsai. 2006). Az acetát termelés szubsztrát szinten az ATP képződését eredményezi, mindemellett a NADH oxidációja szükséges a glikolízis fenntartásához. Az acetil-CoA etanollá való átalakítása az acetaldehiden keresztül két NADH molekulát oxidál, valamint aldehid és alkohol dehidrogenáz aktivitást igényel. Mindkét aktivitás valószínűleg az alkohol/aldehid dehidrogenáz homológok által katalizált (Hemschemeier és Happe 2005; Atteia és mtsai. 2006; Mus és mtsai. 2007). A Chlamydomonas alkohol-dehidrogenáz 1 (ADH1) gén homológiát mutat más kettős funkciójú dehidrogenázokkal, amelyeket rendszerint ADHE-nek hívnak, azért hogy megkülönböztessék a fehérjéket azoktól az alkohol-dehidrogenázoktól, amelyek nem rendelkeznek aldehid-dehidrogenáz aktivitással. Az etanol acetaldehidböl is keletkezhet a piruvát-dekarboxiláz 3 (PDC3) útvonalon, amely közben egy NADH-t is oxidál. A Chlamydomonas ritka az eukarióták között abból a szempontból, hogy mindkét etanol termelő útvonalat tartalmazza. Formát, acetát, etanol a Chlamydomonas sötét fermentációjának fő termékei. Ezek mellett kisebb mennyiségben termelődik még $\mathrm{H}_{2}$ és $\mathrm{CO}_{2}$ (Gfeller és Gibbs 1984; Kreuzberg, 1984; Ohta és mtsai. 1987). Bizonyos körülmények között glicerolt és laktátot is találtak a kultúrákban (Kreuzberg 1984). Az etanol és formát felhalmozódás, valamint a sejtek környezetének szerves savak okozta savasodása toxikus lehet a sejtek számára. Emellett megjelenik az a sejtvédő mechanizmus, amely egyensúlyt teremt az ATP termelés, a NADH oxidáció és a potenciális toxikus fermentatív termékek felhalmozódása között. A formát: acetát: etanol termelődés jellemző arányai 2:1:1 (Gfeller és Gibbs 1984; Kreuzberg 1984), és 2:2:1 (Ohta és mtsai. 1987; Mus és 
mtsai. 2007). A termelési arányokat egyaránt befolyásolják a kultúrák és az indukció körülményeinek változásai és a különbözö törzsek használata is. Továbbá az acetát gyakran előfordul a tápoldatban, és ez a szerves sav az oldat anaerobbá válása során is szekretálódhat a keményítő lebontása nélkül. Ha kizárólag a piruvát-formát liáz 1 (PFL1) felelős a piruvát acetil-CoA-vá alakításáért, akkor a 2:1:1 arány várható a keményítő lebontásából. Kvantitatív RT-PCR alkalmazásával kimutatták, hogy a PFR1 expressziós szintje az anaerobizáció során jelentősen megnövekedett, a HydA1, HydA2, HydEF és HydG transzkriptumaival együtt (Mus és mtsai. 2007). A génexpressziós és metabolikus adatok azt mutatják, hogy anaerob körülmények között a PFR1 útvonal felelős a PFL1 aktivitással együtt a jelentős piruvát katabolizmusért. A sötétben végbemenő fermentatív hidrogéntermelés mértékének erősödése ezáltal a PFR1 útvonal megszakítását eredményezheti, így növelve a hidrogéntermeléshez szükséges redukált ferredoxinok szintjét.

\subsubsection{Hidrogéntermelés alga-baktérium konzorciumokkal}

Az előzőekben ismertetett hidrogéntermelési lehetőségek során azt mutattuk be, hogy egy-egy tiszta monokultúra (akár prokarióta, akár eukarióta) hogyan képes hidrogént termelni. Jelenleg számos olyan módszer áll fejlesztés alatt, amely egy alga törzs és valamely más mikroorganizmus együttes alkalmazásán alapulva biohidrogént képes előállítani. Az egyik legkézenfekvőbb módszer az alga biomassza szubsztrátként való hasznosítása. Ennek során az alga által felhalmozott tartalék tápanyagot, a biomassza előkezelése után egy vagy több hidrogéntermelésre képes baktérium törzs lebontja alacsonyabb energiájú összetevőkre és széndioxidra, miközben biohidrogén keletkezik. Kiváló példa erre a fotoszintetizáló Rhodobium marinum A-501 és a tejsavbaktérium Lactobacillus amylovorus együttmüködése, melynek során szerves forrásként Dunaliella tertiolecta-t és Ch. reinhardtii-t használtak fel. Az L. amylovorus amiláz aktivitása révén a keményítő lebontása során tejsavat állít elő. A $R$. marinum A-501 a tejsav elektrondonorként való felhasználása során pedig megvilágítás mellett biohidrogént termel (Kawaguchi és mtsai. 2001).

További figyelemre méltó biohidrogén termelő közösséget alkot a Ch. reinhardtii-ból, Rhodospirillum rubrum-ból és Clostridium pasteurianum-ból álló összetett rendszer. Ebben az esetben a hidrogéntermelést 3 fázisra osztották a termelésre képes törzsek alapján. Az első fázis során a vas-hidrogenázt tartalmazó zöldalga fotoszintézis útján biomasszát állít elő és biohidrogént termel. A második lépésben az anaerob környezetben müködő fotoszintetikus 
baktérium a fény energiájának felhasználásával szintén biomasszát állít elő, miközben a nitrogenáz enzimének segítségével biohidrogént termel. A harmadik lépésben a zöldalga és fotoszintetikus baktérium által termelt biomasszát bontja le a fermentatív baktérium, ezáltal tovább növelve a teljes megtermelt hidrogén mennyiségét (Melis és mtsai. 2006).

Egy harmadik, többlépéses folyamat során az alga először (Ch. reinhardtii UTEX 90) széndioxid fixálásával fotoszintézis útján keményítőt és nagy molekulasúlyú sejtösszetevőket halmoz fel. Második lépésként a sötét fermentáció során az alga biomasszát a Clostridium butyricum lebontja, amelyből szerves savakat és hidrogéngázt állít elő. Végül a sötét fermentáció során megtermelt szerves savakat a Rhodobacter sphaeroides KD131 fotoszintetikus baktérium hasznosítja, ezáltal biomasszát és hidrogént termel (Kim és mtsai. 2006).

A biohidrogéntermeléshez a baktérium kultúrákat nem csak az előzőekben ismertetett módon lehet hasznosítani. A Ch. reinhardtii cc849-es egy olyan mutáns törzs, amelynek kloroplasztiszában expresszálták a szója leghemoglobin apoproteinjét (lbs). A Bradyrhizobium japonicum Ch. reinhardtii cc849 kultúrához történö hozzáadása egyaránt jótékonyan befolyásolta az alga biomassza növekedését és az alga hidrogéntermelését is. A leghemoglobin fontos szerepet játszik a pillangósvirágú növények gümőjében az oxigén megkötésében, ezáltal elősegítve az anaerob környezet kialakítását és az oxigénre érzékeny nitrogenázok müködését (Appleby 1984; Kundu és mtsai. 2003). Összességében a kevert alga-baktérium kultúrában, a kénmegvonás során az oxigén szintje gyorsabban csökkent és 50\%-kal több hidrogén termelődött, mint a tiszta alga kultúrákban (Wu és mtsai. 2012).

A Ch. reinhardtii cc849 vad típusú törzs hidrogéntermelését kénmegvonás során a mellette azonosított három bakteriális partner egyenkénti hozzáadásával is megvizsgálták. A három azonosított bakteriális törzs a Stenotrophomonas, Microbacteria és Pseudomonas nemzetségekbe tartoztak. A biomassza növekedését a tiszta alga biomassza növekedéséhez képest egyik törzs sem indukálta szignifikáns mértékben, viszont a hidrogéntermelésben jelentős növekedést figyeltek meg. A kevert kultúrák hidrogéntermelés szempontjából legnagyobb előnyének a megnövekedett respirációs aktivitás és az ebből következő gyors és hatékony oxigénszint csökkenés bizonyult ( $\mathrm{Li} 2013)$. 


\section{Célkitüzések}

Számos energiaforrás és energiahordozó között jelentős potenciállal bír a hidrogén, mint energiahordozó. Ennek egy speciális szegmensét képezi a biológiai úton előállítható biohidrogén, amely előállítási technológiájára jelenleg több, kutatás alatt álló módszer létezik. Jelen dolgozat az alga-baktérium kevert kultúrák hidrogéntermelésének tulajdonságaira és a mikrobiális partnerek kapcsolatára fókuszál.

Specifikus célok:

1. A Mosonmagyaróvári Alga Kultúra Gyüjteményből a 4 leghatékonyabb biomassza termelésre képes hidrogéntermelő Chlamydomonas törzs közül az algabaktérium kevert kultúra hidrogéntermelésének vizsgálatára legalkalmasabb algatörzs kiválasztása.

2. A Chlamydomonas sp. 549-es törzs bakteriális partnereinek azonosítása, és a hidrogéntermelést, valamint az alga biomassza hozamot leginkább elősegítő bakteriális partnerek meghatározása.

3. A Chlamydomonas sp. 549 kultúrához hozzáadott természetes (a Mosonmagyaróvári Alga Kultúra Gyűjteményben az alga kultúrák hosszú távú fenntartása során az alga mellett fennmaradt bakteriális partnerek) és mesterséges bakteriális partnerek hatásának vizsgálata a hidrogéntermelésre, az oxigénszint változásra, az algakultúra sejtszám változásaira és a tápoldat összetételbeli változásaira.

4. A kevert és tiszta algakultúrák hidrogéntermelésének tanulmányozása sötétben, valamint fényen kénmegvonás mellett, a különböző hidrogéntermelési módszerek kombinációban történő alkalmazása.

5. A Chlamydomonas sp. 549 fotoszintetikus rendszerének vizsgálata fluoreszcencia mérésekkel, a modell alga hidrogéntermelési útvonalainak azonosítása. 


\section{Anyagok és módszerek}

\begin{tabular}{|c|c|c|}
\hline Törzsek & $\begin{array}{l}\text { Kapcsolódó genotípusok } \\
\text { és fenotípusok }\end{array}$ & Forrás \\
\hline Rhodococcus sp. & vad típus & Jelenlegi munka \\
\hline Leifsonia sp. & vad típus & Jelenlegi munka \\
\hline Brevundimonas sp. & vad típus & Jelenlegi munka \\
\hline Chlamydomonas reinhardtii cc124 & vad típus & Harris 1989 \\
\hline Chlamydomonas sp. 549 & vad típus & MACC \\
\hline Escherichia coli MC4100 & $\Delta h y p F$ & Maier és mtsai. 1996 \\
\hline Escherichia coli K-12 & vad típus & Cohen 1949 \\
\hline Ralstonia eutropha HF441 & $\mathrm{SH}^{-}, \mathrm{MBH}^{-}, \Delta h y p F 1 F 2$ & Wolf és mtsai. 1998 \\
\hline Ralstonia eutropha H16 & vad típus & Holzenburg és mtsai. 1987 \\
\hline
\end{tabular}

1. táblázat: A felhasznált alga és baktérium törzsek listája.

\subsection{Felhasznált anyagok}

TAP tápoldat (Gorman és Levine 1965) (1 L oldathoz)

1. TAP só (1 liter desztillált vízben oldva): $25 \mathrm{~mL}$

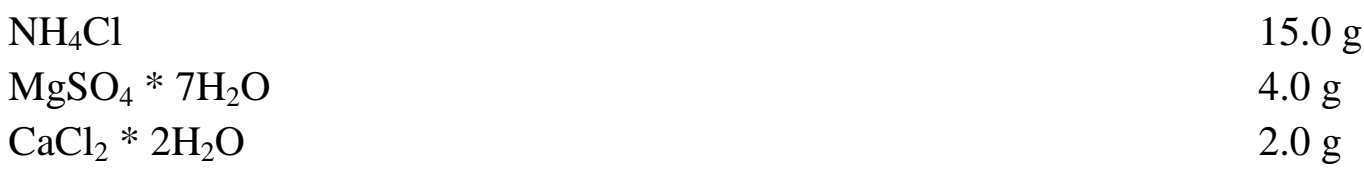

2. Foszfát oldat (100 mL desztillált vízben oldva): $0.375 \mathrm{~mL}$

$\mathrm{K}_{2} \mathrm{HPO}_{4}$

$28.8 \mathrm{~g}$

$\mathrm{KH}_{2} \mathrm{PO}_{4}$

$14.4 \mathrm{~g}$

3. Hutner nyomelemek oldata (Hutner és mtsai. 1950) $10 \mathrm{~mL}$

EDTA dinátrium sója ( $250 \mathrm{~mL}$ desztillált vízben oldva)

$50 \mathrm{~g}$

$\mathrm{ZnSO}_{4} * 7 \mathrm{H}_{2} \mathrm{O}$ (100 mL desztillált vízben oldva)

$22 \mathrm{~g}$

$\mathrm{H}_{3} \mathrm{BO}_{3}(200 \mathrm{~mL}$ desztillált vízben oldva)

$11.4 \mathrm{~g}$

$\mathrm{MnCl}_{2} * 4 \mathrm{H}_{2} \mathrm{O}(50 \mathrm{~mL}$ desztillált vízben oldva)

$5.06 \mathrm{~g}$

$\mathrm{CoCl}_{2}$. $* 6 \mathrm{H}_{2} \mathrm{O}(50 \mathrm{~mL}$ desztillált vízben oldva)

$1.61 \mathrm{~g}$

$\mathrm{CuSO}_{4} * 5 \mathrm{H}_{2} \mathrm{O}(50 \mathrm{~mL}$ desztillált vízben oldva)

$1.57 \mathrm{~g}$

$\left(\mathrm{NH}_{4}\right)_{6} \mathrm{Mo}_{7} \mathrm{O}_{24} * 4 \mathrm{H}_{2} \mathrm{O}(50 \mathrm{~mL}$ desztillált vízben oldva)

$1.10 \mathrm{~g}$

$\mathrm{FeSO}_{4} * 7 \mathrm{H}_{2} \mathrm{O}(50 \mathrm{~mL}$ desztillált vízben oldva $)$ 
4. Tris: $2.42 \mathrm{~g}$

5. Jégecet: $1.0 \mathrm{~mL}$

6. HCl (Tris minimal tápoldathoz)

7. Agar (szilárd táptalaj készítéséhez): $15 \mathrm{~g} \mathrm{~L}^{-1}$

Bristol tápoldat Bold által módosítva (Bold 1949) (1 L oldathoz)

1. Törzsoldat ( $250 \mathrm{~mL}$ desztillált vízben feloldva): $10 \mathrm{~mL}$

$\mathrm{NaNO}_{3}$

$\mathrm{CaCl}_{2} * 2 \mathrm{H}_{2} \mathrm{O}$

$\mathrm{MgSO}_{4} * 7 \mathrm{H}_{2} \mathrm{O}$

$\mathrm{K}_{2} \mathrm{HPO}_{4}$

$\mathrm{KH}_{2} \mathrm{PO}_{4}$

$\mathrm{NaCl}$
$6,25 \mathrm{~g}$

$0,625 \mathrm{~g}$

$1,875 \mathrm{~g}$

$1,875 \mathrm{~g}$

$4,375 \mathrm{~g}$

$0,625 \mathrm{~g}$

$5 \mathrm{~g}$

$3,1 \mathrm{~g}$

$0,498 \mathrm{~g}$

$0,1 \mathrm{~mL}$

$\mathrm{H}_{2} \mathrm{SO}_{4}$

4. Törzsoldat (100 mL desztillált vízben feloldva): $1 \mathrm{~mL}$ $\mathrm{H}_{3} \mathrm{BO}_{3}$

$1,142 \mathrm{~g}$

5. Törzsoldat (100 mL desztillált vízben feloldva): $1 \mathrm{~mL}$

$\mathrm{ZnSO}_{4} * 7 \mathrm{H}_{2} \mathrm{O}$

$0,882 \mathrm{~g}$

$\mathrm{MnCl}_{2} * 4 \mathrm{H}_{2} \mathrm{O}$

$0,144 \mathrm{~g}$

$\mathrm{Na}_{2} \mathrm{MoO}_{4} * 2 \mathrm{H}_{2} \mathrm{O}$

$0,242 \mathrm{~g}$

$\mathrm{CuSO}_{4} * 5 \mathrm{H}_{2} \mathrm{O}$

$0,157 \mathrm{~g}$

$\mathrm{Co}\left(\mathrm{NO}_{3}\right)_{2} * 6 \mathrm{H}_{2} \mathrm{O}$
$0,049 \mathrm{~g}$

Zehnder Z 8 tápoldat (Kotai 1972) (1 L oldathoz)

1. Törzsoldat (300 $\mathrm{mL}$ desztillált vízben feloldva): $3 \mathrm{~mL}$ 
$\mathrm{NaNO}_{3}$

$\mathrm{Ca}\left(\mathrm{NO}_{3}\right)_{2}$

$\mathrm{MgSO}_{4} * 7 \mathrm{H}_{2} \mathrm{O}$

2. Törzsoldat (300 mL desztillált vízben feloldva): $1 \mathrm{~mL}$

$\mathrm{K}_{2} \mathrm{HPO}_{4}$

$\mathrm{Na}_{2} \mathrm{CO}_{3}$

3. Törzsoldat (500 mL desztillált vízben feloldva): $10 \mathrm{~mL}$

$\mathrm{FeCl}_{3} * 6 \mathrm{H}_{2} \mathrm{O}+\mathrm{HCl}$ (150 mL desztillált vízben feloldva) $5 \mathrm{~mL}$

$\mathrm{Na}_{2}$-EDTA (150 mL desztillált vízben feloldva) $5 \mathrm{~mL}$

4. Törzsoldat (500 $\mathbf{~ m L}$ desztillált vízben feloldva): $0,08 \mathrm{~mL}$

$\mathrm{Na}_{2} \mathrm{SiO}_{3} * 9 \mathrm{H}_{2} \mathrm{O}$

$\mathrm{H}_{3} \mathrm{BO}_{3}$

$\mathrm{MnCl}_{2} * 4 \mathrm{H}_{2} \mathrm{O}$

$\left(\mathrm{NH}_{4}\right)_{6} \mathrm{Mo}_{7} \mathrm{O}_{24} * 4 \mathrm{H}_{2} \mathrm{O}$

$\mathrm{KBr}$

$\mathrm{KI}$

$\mathrm{ZnSO}_{4} * 7 \mathrm{H}_{2} \mathrm{O}$

$\mathrm{Co}\left(\mathrm{NO}_{3}\right)_{2} * 6 \mathrm{H}_{2} \mathrm{O}$

$\mathrm{CuSO}_{4} * 5 \mathrm{H}_{2} \mathrm{O}$

$\mathrm{Al}_{2}\left(\mathrm{SO}_{4}\right)_{3} * 18 \mathrm{H}_{2} \mathrm{O}$

$\mathrm{LiCl} * \mathrm{H}_{2} \mathrm{O}$
$46,7 \mathrm{~g}$

$5,9 \mathrm{~g}$

$2,5 \mathrm{~g}$

$9,3 \mathrm{~g}$

$6,3 \mathrm{~g}$

$1,3515 \mathrm{~g}$ és $1,5 \mathrm{~mL}$ $2,1915 \mathrm{~g}$

$25,0 \mathrm{mg}$

$1550,0 \mathrm{mg}$

$1115,0 \mathrm{mg}$

$44,0 \mathrm{mg}$

$59,5 \mathrm{mg}$

$41,5 \mathrm{mg}$

$143,5 \mathrm{mg}$

$73,0 \mathrm{mg}$

$62,5 \mathrm{mg}$

$237,0 \mathrm{mg}$

$25,0 \mathrm{mg}$

Sueoka tápoldat (Sueoka 1960) (1 L oldathoz)

1. Sóoldat (1 L desztillált vízben feloldva): $5 \mathrm{~mL}$

$\mathrm{NH}_{4} \mathrm{Cl}$

$100.0 \mathrm{~g}$

$\mathrm{MgSO}_{4} \cdot 7 \mathrm{H}_{2} \mathrm{O}$

$4.0 \mathrm{~g}$

$\mathrm{CaCl}_{2} \cdot 2 \mathrm{H}_{2} \mathrm{O}$

$2.0 \mathrm{~g}$

2. Foszfát oldat (1 L desztillált vízben feloldva): $5 \mathrm{~mL}$

$\mathrm{K}_{2} \mathrm{HPO}_{4}$

$\mathrm{KH}_{2} \mathrm{PO}_{4}$

3. Hutner nyomelemek oldata (1 L desztillált vízben feloldva): $1 \mathrm{~mL}$

Kuhl tápoldat (Kuhl 1962)

1. Törzsoldat (300 mL desztillált vízben feloldva): $10 \mathrm{~mL}$ 
2. Fe-oldat (1 L desztillált vízben feloldva): $1 \mathrm{~mL}$

$\mathrm{FeSO}_{4} * 7 \mathrm{H}_{2} \mathrm{O}$

$0,69 \mathrm{~g}$

$\mathrm{Na}_{2}$-EDTA

\section{Nyomelem oldat}

$1 \mathrm{~L}$ desztillált vízben feloldva: $1 \mathrm{~mL}$

$\mathrm{H}_{3} \mathrm{BO}_{3}$

$61 \mathrm{mg}$

$\mathrm{MnSO}_{4} * \mathrm{H}_{2} \mathrm{O}$

$169 \mathrm{mg}$

$\mathrm{ZnSO}_{4} * 7 \mathrm{H}_{2} \mathrm{O}$ $287 \mathrm{mg}$

100-100 mL desztillált vízben feloldva: $1 \mathrm{~mL}$

$\mathrm{CuSO}_{4} * 5 \mathrm{H}_{2} \mathrm{O}$

LB (Luria Broth) tápoldat (Sambrook és Russel 2001) (1 L tápoldathoz):

Tripton: $10 \mathrm{~g}$

Élesztő kivonat: $5 \mathrm{~g}$

$\mathrm{NaCl}: 10 \mathrm{~g}$

DCMU (3-(3,4-dichlorophenyl)-1,1-dimethylurea) (10 mL törzsoldathoz): $0.025 \mathrm{~g}$

\subsection{Alga kultúrák biomassza növekedésének vizsgálata}

A mosonmagyaróvári törzsgyüjteményben 100 mL-es Erlenmeyer-lombikokban agarral szilárdított tápoldatban, alacsony hőmérsékleten $\left(\begin{array}{llll}15 & \pm & { }^{\circ} \mathrm{C}\end{array}\right)$ fenntartott Chlamydomonas törzseket $250 \mathrm{~mL}$ Bristol tápoldatot tartalmazó $500 \mathrm{~mL}$-es Erlenmeyerlombikokba oltottuk. E tenyészeteket $25 \pm 2{ }^{\circ} \mathrm{C}$ hőmérsékletű alga tenyésztô-tesztelő laboratóriumban 14 órás megvilágítás és $130 \mu \mathrm{mol} \mathrm{m} \mathrm{m}^{-2} \mathrm{~s}^{-1}$ fényintenzitás mellett 7 napig tenyésztettük. A tenyészeteken óránként 20 liter $1,5 \% \quad \mathrm{CO}_{2}$-ot tartalmazó levegőt áramoltattunk át. Hét nap elteltével mértük a tenyészetek szárazanyagtartalmát, majd azokat 
$10 \mathrm{mg} \mathrm{L}{ }^{-1}$ induló szárazanyag-tartalommal $250 \mathrm{~mL}$ Zehnder-8, Bristol, Kuhl és Sueoka tápoldatokba oltottuk tovább. Az elért biomassza alapján, a 4 tápoldatból kiválasztottuk az adott törzs számára legmegfelelőbbet és $10 \mathrm{mg} \mathrm{L}^{-1}$ induló szárazanyag-tartalommal szintén $250 \mathrm{~mL}$ tápoldatot tartalmazó lombikokba oltottuk tovább. Tenyészeteinket azonos körülmények mellett, az alga tenyésztő-tesztelő szobákban 12 napig inkubáltuk, melyekből 2 naponta a szárazanyag meghatározására 3 ismétlésben mintákat vettünk. Az eredményekből átlagot és szórást számoltunk.

\subsection{Tiszta és kevert kultúrák növesztése}

A felhasznált algatörzsek a Mosonmagyaróvári Alga Kultúra Gyüjteményből származnak (MACC). A MACC-t 1992-ben alapította a Nyugat Magyarországi Egyetem Növénybiológiai Intézete. A MACC Európa harmadik legnagyobb talajlakó alga kultúra gyüjteménye, amely 588 javarészt Brazíliából származó szárazföldi és 382 vízi mikroalgát tartalmaz, beleértve 70 Chlamydomonas törzset.

A Chlamydomonas sp. 549 és a Ch. reinhardtii cc124 törzseket a bakteriális fertőzések kiküszöbölésére rifampicinnel kiegészített, ecetsavat nem tartalmazó TP (Tris-foszfát tápoldat) tápoldaton tartottuk fenn. A TP tápoldat egy olyan módosított TAP tápoldat, ahol az ecetsav sósavval van helyettesítve. A TP lemezeket $25{ }^{\circ} \mathrm{C}$-on $50 \mu \mathrm{mol} \mathrm{m}{ }^{-2}$ perc ${ }^{-1}$ erősségü fény alatt inkubáltuk. A hidrogéntermelési kísérletekhez használt algákat frissen, rifampicinnel kiegészített és agarral szilárdított TP lemezeken növesztettük, majd folyékony TAP (Tris-acetát-foszfát tápoldat) tápoldatba oltottuk le (Gorman és Levine 1965). A kénmegvonás során az algákat az előzőekben leírtak alapján növesztettük fel, majd mielőtt leoltottuk volna őket a kénmentes TAP tápoldatban (TAP-S) tápoldatba, háromszor feloldottuk és lecentrifugáltuk a TAP-S tápoldatban. Az alga törzsoldatokat úgy osztottuk el egyenlően a $40 \mathrm{~mL}$-es szérum üvegekben, hogy a végtérfogatuk $35 \mathrm{~mL}$, a végső optikai denzitásuk pedig 750 nm-en mérve 0.7 lett. Az alga-baktérium kevert kultúrákból különböző, jól elkülöníthető fenotípussal rendelkező bakteriális kolóniákat izoláltunk. A vad típusú és hidrogenáz deficiens Escherichia coli és Ralstonia eutropha bakteriális törzseket a Magyar Tudományos Akadémia Szegedi Biológiai Kutatóintézetének a Biokémiai Intézetéből, valamint a Szegedi Tudományegyetem Biotechnológia Tanszékéről szereztük be. Az izolált baktériumokat (az E. coli-t és a $R$. eutropha-t) sötétben, $30^{\circ} \mathrm{C}$-on LB (Luria-Bertani tápoldat) lemezen növesztettük és tartottuk fenn. A Chlamydomonas sp. 549 mellöl izolált 
Rhodococcus sp. két nap, míg a Brevundimonas sp. és a Leifsonia sp. három nap után nőtt fel és képzett jól látható telepeket. A kevert alga-baktérium kultúrákhoz használt baktérium törzseket agarral szilárdított lemezen növesztettük, majd innen folyékony TAP tápoldatba helyeztük. A bakteriális törzsoldatot egyenlően elosztottuk a $40 \mathrm{~mL}$-es szérum üvegekbe, úgy hogy a végső térfogatuk $35 \mathrm{~mL}$, az optikai denzitásuk pedig $600 \mathrm{~nm}$-en 0.5 legyen. Az algabaktérium kevert kultúrákat úgy hoztuk létre, hogy összekevertük az alga és a baktérium törzsoldatokat a $40 \mathrm{~mL}$-es szérum üvegekben úgy, hogy $35 \mathrm{~mL}$ legyen a végtérfogatuk az előzőekben megadott optikai denzitás értékek mellett. Az üvegeket butilgumi és alumíniumkupak használatával zártuk le légmentesen. Minden kísérlethez három párhuzamos mintát használtunk.

\subsection{A természetes bakteriális partnerek meghatározása}

Az egyes tiszta baktérium kultúrákból a genomi DNS-t hagyományos DNS izolálással nyertük ki, majd az így kapott tisztított DNS-t a 16S rDNS szekvenciák amplifikálásán alapuló polimeráz láncreakció (PCR) felhasználásával határoztuk meg (Green és Sambrook 2012). Az amplifikációhoz univerzális 16S rDNS oligonukleotidokat használtunk (f27 5'AGAGTTTGATCCTGGCTCAG-3' és r1492 5'-ACGGCTACCTTGTTACGACTT-3'). A körülbelül 1500 kbp hosszú PCR termékeket agaróz gélből izoláltuk, majd kapilláris Sanger szekvenálással, mindkét végtől számított kb. 750 bp hosszúságú szakasz alapján határoztuk meg a polimeráz reakció termékének pontos szekvenciáját. A $16 \mathrm{~S}$ rDNS szekvenciák eredetének meghatározásához a BLAST (http://blast.ncbi.nlm.nih.gov/) homológ szekvenciakeresőjét alkalmaztuk.

\subsection{Az alga és baktérium sejtszámok meghatározása}

Az alga kultúrák optikai denzitását 750 nm-en, a baktérium kultúrákét 600 nm-en mértük. Az alga sejtszámot Bürker-kamra használatával számoltuk meg. A Bürker-kamrára $10 \mu$ L-nyi mintát pipettáztunk és mikroszkóp alatt számoltuk meg a sejteket. Az élő baktérium sejtszámot úgy határoztuk meg, hogy a tízezerszeresére kihígított kultúrából $50 \mu \mathrm{L}$ t LB lemezre szélesztettünk. 


\subsection{Hidrogén és oxigén analitikai mérése}

A szérum üvegek légterének hidrogén és oxigén szintjét gázkromatográf (GC) segítségével mértük meg. A méréseinkhez egy hővezetőképességi detektorral és Agilent HPMolsieve oszloppal (hossz $30 \mathrm{~m}$, átmérő $0.32 \mathrm{~mm}$, film réteg $12.0 \mu \mathrm{m}$ ) felszerelt Agilent 7890A típusú gázkromatográfot használtunk. Vivő és referencia gázként Linde HQ 5.0-ás tisztaságú argon gázt alkalmaztunk. Az injektor, a hővezetőképességi detektor és az oszlop hőmérséklete $150{ }^{\circ} \mathrm{C}, 160{ }^{\circ} \mathrm{C}$ és $60^{\circ} \mathrm{C}$ voltak. Az oszlop nyomása 47,618 psi-re lett állítva. $\mathrm{Az}$ oszlop áramlási sebessége $12 \mathrm{~mL}$ perc $^{-1}$ volt. Minden méréshez $50 \mu \mathrm{L}$ gázmintát fecskendeztünk az injektorba. Minden méréshez három párhuzamos mintát használtunk.

A pontos gázmennyiségek meghatározásához hidrogén kalibrációs egyenest használtunk. A hidrogén kalibrációs egyenes létrehozásához hígítási sort hoztunk létre eltérő mennyiségü tiszta hidrogén $25 \mathrm{~mL}$-es szérum üvegekbe fecskendezésével. Ezekből azonos mennyiséget fecskendeztünk a gázkromatográfba háromszori ismétléssel, majd az így kapott eredményekből állítottuk fel a kalibrációs egyenest. A GC egységek átalakításához a következő egyenletet használtuk: $\mathrm{x}=\mathrm{y} / 239.13$ (x: a tiszta hidrogén térfogata $\mu$ l-ben, $\mathrm{y}$ : mért GC egység). A mért hidrogén mennyiségeket, az adatok grafikonon való ábrázolásához $1 \mathrm{~L}$ alga kultúrára normalizáltuk: $\mathrm{x}=\mathrm{y} / 239.13 * 2857$.

Az oxigén mennyiségeket a környezeti oxigénkoncentrációhoz viszonyítottuk. A mért oxigén mennyiségeket elosztottuk az átlagos környezeti oxigén GC mennyiségével, majd megszoroztuk a környezeti oxigén mennyiséggel: $\mathrm{x}=\mathrm{y} / 438.57 * 21$ (x: oxigén szint százalékban, y: mért GC egység).

\subsection{Az oldott oxigén koncentrációjának meghatározása}

$\mathrm{Az}$ oldott oxigénkoncentráció értékeit folyamatosan mértük $25{ }^{\circ} \mathrm{C}$-on a kultúra folyadékfázisában egy száloptikás oxigénmérő berendezés segítségével (Precision Sensing GmbH, Fibox 3 Minisensor oxigénmérő, Németország). A kalibrálást hőmérsékletérzékelő nélkül végeztük oxigénmentes $\left(1 \mathrm{~g} \mathrm{Na}_{2} \mathrm{SO}_{3} 100 \mathrm{~mL}\right.$ vízben oldva) illetve oxigénnel telített víz kétpontos konvencionális kalibrációját használva. 


\subsection{A fotoszintézis gátlása}

A fotoszintetikus elektrontranszportlánc $\mathrm{Q}_{\mathrm{B}}$ kötöhelyének blokkolásához a herbicid DCMU-t (3-[3,4-dichlorophenyl]-1,1-dimethylurea) (Metz és mtsai. 1986) használtuk 200 «M végső koncentrációban (Velthuys 1981, Wraight 1981, Volgusheva és mtsai. 2013).

\subsection{Klorofill fluoreszcencia mérések}

A klorofill (Chl) fluoreszcencia változásainak a detektálása kellően érzékeny módszert nyújt a II. fotokémiai rendszer (PSII) aktivitásának vizsgálatához (Papageorgiou 2004). A sötétadaptált fotoszintetikus minták folyamatos aktinikus fénnyel történő megvilágítása során a fluoreszcencia az alacsony $\mathrm{F}_{\mathrm{o}}$ ( $\mathrm{O}$-origo $10 \mu$ s-nál mérve) értékről a maximális $\mathrm{F}_{\mathrm{m}}$ (P-csúcs 200 ms-nál) értékre emelkedik a jellemző háromfázisú kinetikát (köztes lépések: J 3 msnál, I 20 ms-nál) követve (Strasser és Srivastava 1995, Papageorgiou és mtsai. 2007). A klorofill fluoreszcencia fényfüggő változásai lényegében a PSII elsődleges kinon elektron akceptora, a $\mathrm{Q}_{\mathrm{A}}$ redox állapota által meghatározottak, de egyben képet adnak a fotoszintetikus elektrontranszportlánc redukáltsági állapotáról is (Schansker és mtsai. 2005). Az OJIP (gyors Chl a fluoreszcencia indukció) tranziens fotokémiai része az OJ fázis, melynek a relatív amplitúdója a PQ-pool redox állapotát mutatja oly módon, hogy minél magasabb a $\mathrm{PQH}_{2} / \mathrm{PQ}$ aránya a sötétben, annál magasabb a J értéke (Tóth és mtsai. 2007).

A fényimpulzus-indukált fluoreszcencia növekedés és az azt követő lecsengés, valamint a folytonos megvilágítás melletti gyors fluoreszcens indukció méréséhez a mintákat először 3 percig sötétadaptáltuk, majd a kettős modulációra képes FL3000 fluorométerrel (Photon System Instruments, Csehország) detektáltuk a fluoreszcenciát. A fényimpulzusindukált fluoreszcencia változások mérésekor a mintát $30 \mu$ s-os telítési intenzitású fényimpulzussal világítottuk meg, majd a fluoreszcencia jelet a $150 \mu \mathrm{s}-100 \mathrm{~s}$ időintervallumban, logaritmikus időskálán jelenítettük meg (Trtílek és mtsai. 1997). A gyors fluoreszcencia növekedést $1000 \mu \mathrm{mol} \mathrm{m} \mathrm{m}^{-2}$ aktinikus fénnyel indukáltuk, majd az OJIP tranzienst $10 \mu \mathrm{s}-2 \mathrm{~s}$ időskálán mértük. A kevert mintákat a kísérletek és a mérések alatt légmentesen zárt küvettákban tartottuk.

A fényimpulzus-indukált fluoreszcencia hatásfok lecsengési kinetikáját egy másik tanulmány leírása alapján vizsgáltuk (Vass és mtsai. 1999). A monoton csökkenő görbék az 
alábbi, két exponenciális (gyors és középső fázis) és egy hiperbolikus komponenst (lassú fázis) tartalmazó függvénnyel illeszthetők:

$$
F_{\mathrm{v}, \text { corr }}=A_{1} \exp \left(-t / T_{1}\right)+A_{2} \exp \left(-t / T_{2}\right)+A_{3} /\left(1+t / T_{3}\right)+A_{0}
$$

Az $F_{\mathrm{v}}=F(\mathrm{t})-F_{\mathrm{o}}$, ahol $F(\mathrm{t})$ mutatja a fluoreszcencia értéket a $t$ időpontban, az $F_{\mathrm{o}}$ a fényindukció előtti alap fluoreszcencia értéket, az $A_{1}-A_{3}$ az amplitúdót, valamint a $T_{1}-T_{3}$ az idő állandókat. A mérések időtartama alatt nem lecsengő fluoreszcencia összetevőt az $A_{0}$ állandó jelöli. Az $F_{\mathrm{v}, \text { corr }}$ a változó fluoreszcencia érték nemlineáris korrekciója a Joliot (Joliot és Joliot 1964) modell alapján.

A $\mathrm{F}_{\mathrm{V}} / \mathrm{F}_{\mathrm{M}}$ fluoreszcencia paramétert, $F_{\mathrm{v}} / F_{\mathrm{m}}=\left(F_{\mathrm{m}}-F_{\mathrm{o}}\right) / F_{\mathrm{m}}$, a Dual-PAM-100 (Walz, Németország) fluorométerrel határoztuk meg (Schreiber és mtsai. 1986, Perreault és mtsai. 2009). A minimum és maximum klorofill fluoreszcencia értéket, $F_{\mathrm{o}}$ és $F_{\mathrm{m}}, 10$ percnyi sötétadaptálás után határoztuk meg. A maximum értéket a légmentesen zárt szérum üvegekben lévő kultúrák $600 \mathrm{~ms}$ hosszúságú $10000 \mu \mathrm{mol} \mathrm{\textrm {m } ^ { - 2 }} \mathrm{s}^{-1}$ erősségű telítési fényimpulzussal történő megvilágításával értük el.

\subsection{Ecetsav analitikai mérése}

Az ecetsav szintet HPLC-vel mértük. A készülék Gynkotek M 480-as pumpával, egy TOSOH 6040 UV detektorral $(210 \mathrm{~nm})$, egy $20 \mathrm{~mL}$-es hurkot tartalmazó Rheodyne 8125 injektorral és egy Aminex HPX-87H oszloppal (300 x 7.8 mm; 5 mm) (BioRad Co., USA) volt felszerelve. Mobil fázisként $0.005 \mathrm{M} \mathrm{H}_{2} \mathrm{SO}_{4}$-et használtunk $600 \mu \mathrm{L}$ perc ${ }^{-1}$ áramlási sebességgel a $60{ }^{\circ} \mathrm{C}$-ra felfütött hömérsékletü oszlopon. A mérésekhez $20 \mu \mathrm{L}$ mintát fecskendeztünk be. Az ecetsav mennyiségi analíziséhez ötpontos kalibrációt használtunk (Sigma-Aldrich Co., USA). Minden méréshez három párhuzamos mintát használtunk. 


\section{Eredmények}

\subsection{Alga és baktérium biomassza vizsgálatok}

\subsubsection{Chlamydomonas törzsek biomassza hozamának vizsgálata}

A mosonmagyaróvári alga-törzsgyüjtemény (MACC) 70 Chlamydomonas törzséböl 25 hidrogéntermelésre alkalmas törzset választottunk ki a szaporodási paramétereik vizsgálatának céljából. A biomassza növekedésének vizsgálatához négy különböző típusú tápoldatot használtunk. A törzsgyüjteményben tárolt, előnövesztett kultúrákat Zehnder Z8, Bristol, Kuhl és Sueoka (Kotai 1972, ,Bold 1949, Kuhl 1962, Sueoka 1960) tápoldatokba oltottuk le. 12 napig növesztettük és mértük az egyes kultúrák biomassza hozamát napi 14 órás megvilágítás és 1,5\% széndioxidot tartalmazó levegő áramoltatása mellett, a sejtosztódás szempontjából legelőnyösebb $25{ }^{\circ} \mathrm{C}$-os hőmérsékleten. A 12. napi eredmények alapján választottuk ki a további kísérletekhez használt algát (1. táblázat). Választásunk a Chlamydomonas sp. 549-es algára esett.

\begin{tabular}{|c|c|c|c|c|}
\hline & \multicolumn{2}{|r|}{ Algatörzs } & \multirow{2}{*}{ Tápoldat } & \multirow{2}{*}{$\begin{array}{l}\text { 12. napon mért szárazanyag } \\
\left(\mathrm{mg} \mathrm{L}^{-1}\right)\end{array}$} \\
\hline & Száma & Neve & & \\
\hline 1. & MACC-549 & Chlamydomonas sp. & Kuhl & $3346,67 \pm 560,47$ \\
\hline 2. & MACC-810 & Chlamydomonas sp. & Kuhl & $3083,33 \pm 197,57$ \\
\hline 3. & MACC-772 & Ch. reinhardtii & Kuhl & $2860,00 \pm 121,65$ \\
\hline 4. & MACC-530 & Chlamydomonas sp. & Kuhl & $2793,33 \pm 515,49$ \\
\hline 5. & MACC-783 & Chlamydomonas sp. & Zehnder-8 & $2786,67 \pm 172,43$ \\
\hline 6. & MACC-53 & Chlamydomonas debaryana & Kuhl & $2540,00 \pm 330,45$ \\
\hline 7. & MACC-601 & Chlamydomonas sp. & Bristol & $2500,00 \pm 140$ \\
\hline 8. & MACC-460 & Chlamydomonas sp. & Kuhl & $2460,00 \pm 87,18$ \\
\hline 9. & MACC-406 & Chlamydomonas sp. & Kuhl & $2413,33 \pm 397,16$ \\
\hline 10 . & MACC-688 & Chlamydomonas sp. & Bristol & $2286,67 \pm 300,89$ \\
\hline 11. & MACC-693 & Chlamydomonas sp. & Sueoka & $2270 \pm 389,36$ \\
\hline 12 . & MACC-482 & Chlamydomonas sp. & Zehnder-8 & $2146,67 \pm 283,78$ \\
\hline
\end{tabular}




\begin{tabular}{|c|c|c|c|c|}
\hline 13. & MACC-382 & Chlamydomonas sp. & Kuhl & $2086,67 \pm 266,33$ \\
\hline 14. & MACC-216 & Ch. reinhardtii & Bristol & $2060,00 \pm 60$ \\
\hline 15. & MACC-335 & Chlamydomonas sp. & Zehnder-8 & $2013,33 \pm 362,95$ \\
\hline 16. & MACC-531 & Chlamydomonas sp. & Sueoka & $2006,67 \pm 494$ \\
\hline 17. & MACC-487 & Chlamydomonas sp. & Kuhl & $1993,33 \pm 376,47$ \\
\hline 18. & MACC-788 & Ch. reinhardtii & Kuhl & $1946,67 \pm 266,33$ \\
\hline 19. & MACC-821 & Chlamydomonas sp. & Bristol & $1893,33 \pm 25,17$ \\
\hline 20. & MACC-395 & Chlamydomonas sp. & Zehnder-8 & $1816,67 \pm 187,17$ \\
\hline 21. & MACC-388 & Chlamydomonas sp. & Bristol & $1500,00 \pm 202,98$ \\
\hline 22. & MACC-285 & Chlamydomonas sp. & Bristol & $1453,33272,27$ \\
\hline 23. & MACC-786 & Chlamydomonas sp. & Kuhl & $1306,67 \pm 320,21$ \\
\hline 24. & MACC-816 & Chlamydomonas sp. & Bristol & $863,33 \pm 92,91$ \\
\hline 25. & MACC-819 & Chlamydomonas sp. & Zehnder-8 & $476,67 \pm 217,79$ \\
\hline
\end{tabular}

2. táblázat: A vizsgált törzsek biomassza-termelése a 12. napon mért szárazanyag értékek átlaga alapján. Három párhuzamos biológiai mintán, mintánként három technikai mérést végeztünk, majd a kapott eredményekből átlagot és szórást számoltunk.

\subsubsection{A Chlamydomonas sp. 549 természetes bakteriális fertőzéseinek vizsgálata}

A hosszas tárolás és a rendszeres átoltások során, a kultúra gyüjteményben a Chlamydomonas sp. 549 különböző bakteriális fajokkal fertőzödött meg. A fertőzésnek jól látható jele volt a TAP folyadékkultúra üvegének falán képződő baktériumokból álló biofilmréteg és az agarral szilárdított TAP lemezen felnövesztett alga kultúrák kolóniáinak peremén látható eltérő színű karimák megjelenése. A természetes bakteriális partnereket LB lemezekre leoltva, $30{ }^{\circ} \mathrm{C}$-on inkubálva, többszörös átoltás után fizikailag elválasztottuk egymástól és a Chlamydomonas algától is. Azonosításukhoz 16S rDNS amplifikációján alapuló kapilláris DNS szekvenálást alkalmaztunk. A fenotipikusan jól elkülöníthető baktérium nemzetségek a következök voltak: Brevundimonas, Rhodococcus és Leifsonia. Az így kapott törzseket a későbbi vizsgálatokhoz LB lemezen tartottuk fenn, illetve hosszú távú 
fenntartásuk és megőrzésük céljából LB és glicerin keverékébe ágyazva $-80{ }^{\circ} \mathrm{C}$-on a labor törzsgyüjteményében helyeztük el.

A tiszta algakultúra létrehozásához többszörös átoltást végeztünk, melyhez TP (ecetsav-mentes) minimál tápoldatot használtunk. A tisztítás hatékonyságának fokozása érdekében a minimál táptalajhoz szelektív antibiotikumokat adtunk. A megfelelö, mindhárom baktérium törzs növekedését kielégítően gátló antibiotikum kiválasztásához, 10 különböző típusú antibiotikumot teszteltünk mind a baktériumokon, mind az algán: ampicillin $100 \mathrm{mg} /$ $\mathrm{mL}$, gentamicin $20 \mathrm{mg} / \mathrm{mL}$, kanamicin $50 \mathrm{mg} / \mathrm{mL}$, sztreptomicin $100 \mathrm{mg} / \mathrm{mL}$, rifampicin $50 \mathrm{mg} / \mathrm{mL}$, tetraciklin $10 \mathrm{mg} / \mathrm{mL}$, nalidixsav $10 \mathrm{mg} / \mathrm{mL}$, szpektinomicin $100 \mathrm{mg} / \mathrm{mL}$, neomicin $100 \mathrm{mg} / \mathrm{mL}$, klaritromicin $25 \mathrm{mg} / \mathrm{mL}$. Az algát és a baktériumokat tartalmazó lemezeken korong diffúziós tesztet használtunk, melynek során $30 \mu \mathrm{L}$ ezerszeresére higított antibiotikum törzsoldatokat cseppentettünk a papírkorongokra, majd megfigyeltük, hogy hol alakul ki a korongok körül feltisztulási zóna.

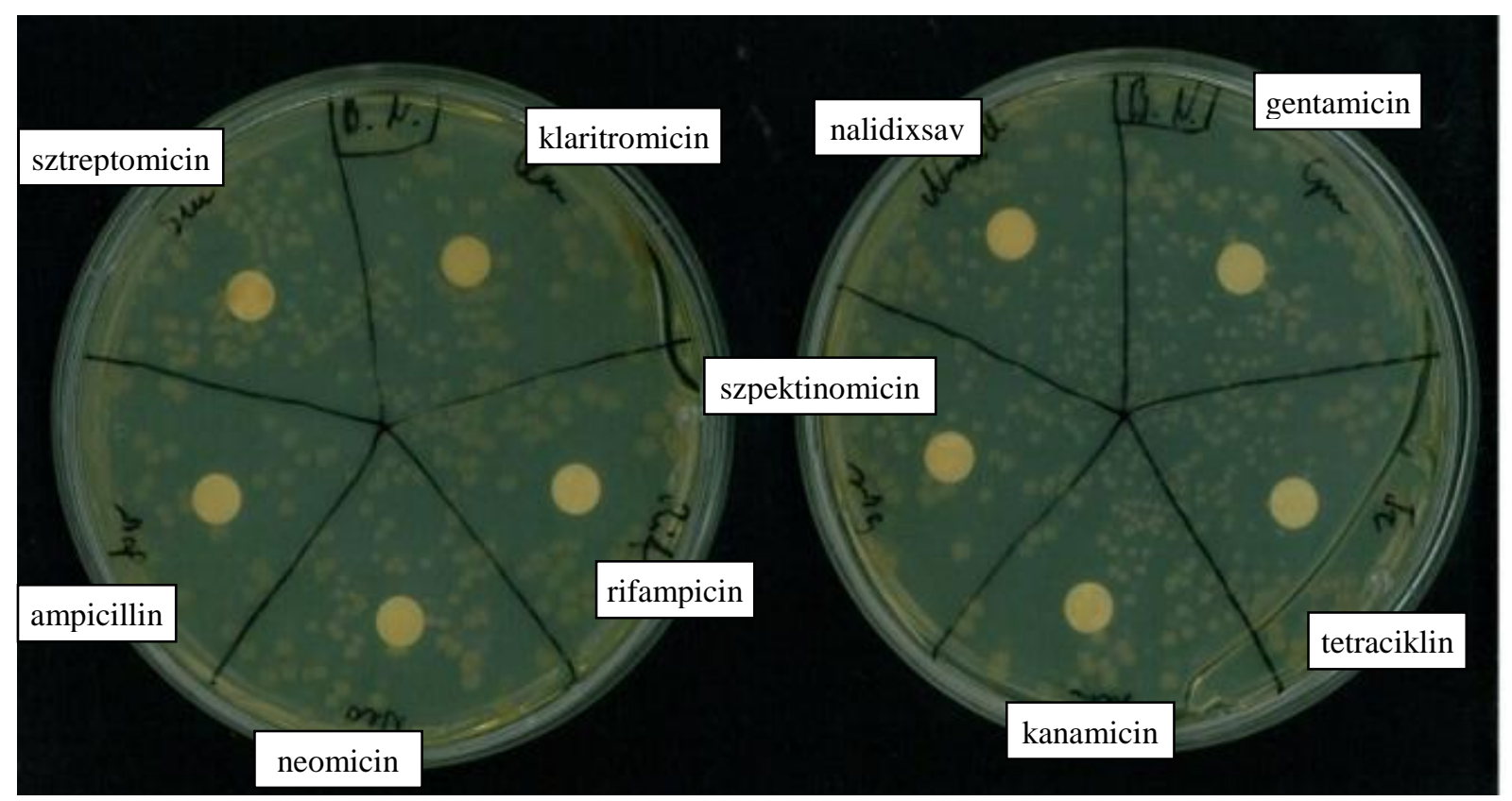

1. ábra: Antibiotikum teszt Brevundimonas-szal. 


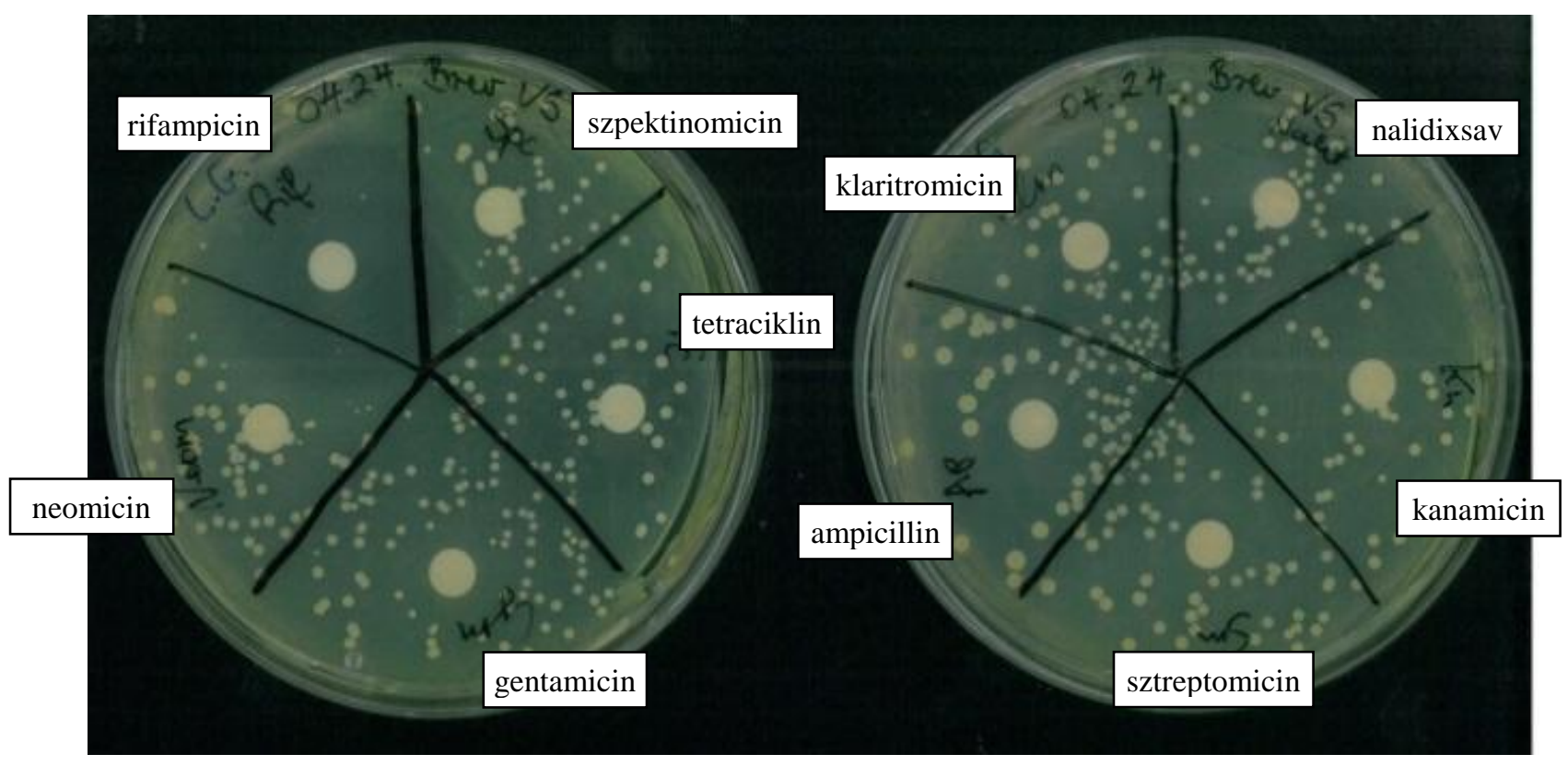

2. ábra: Antibiotikum teszt Leifsonia-val.

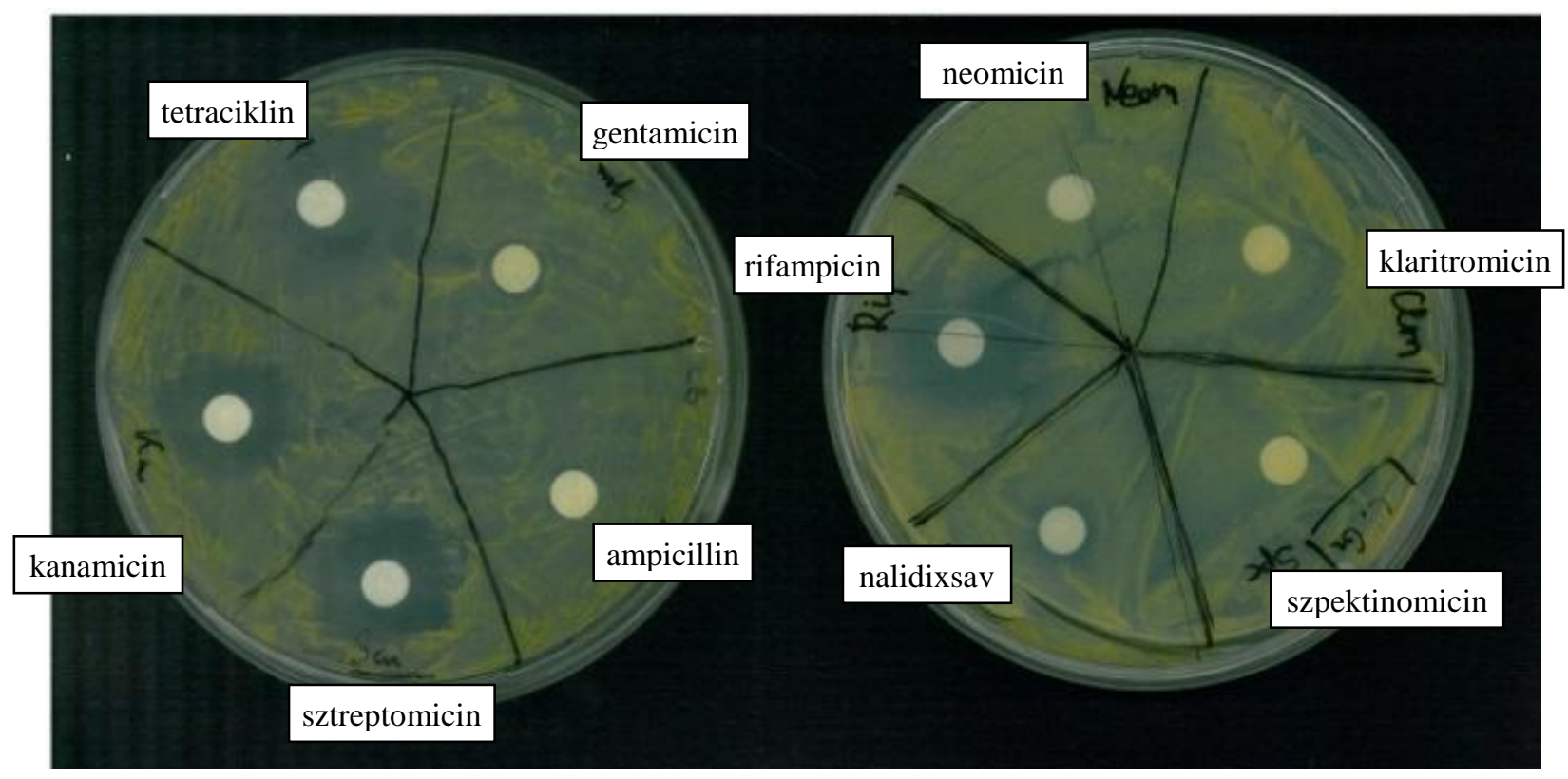

3. ábra: Antibiotikum teszt Rhodococcus-szal. 


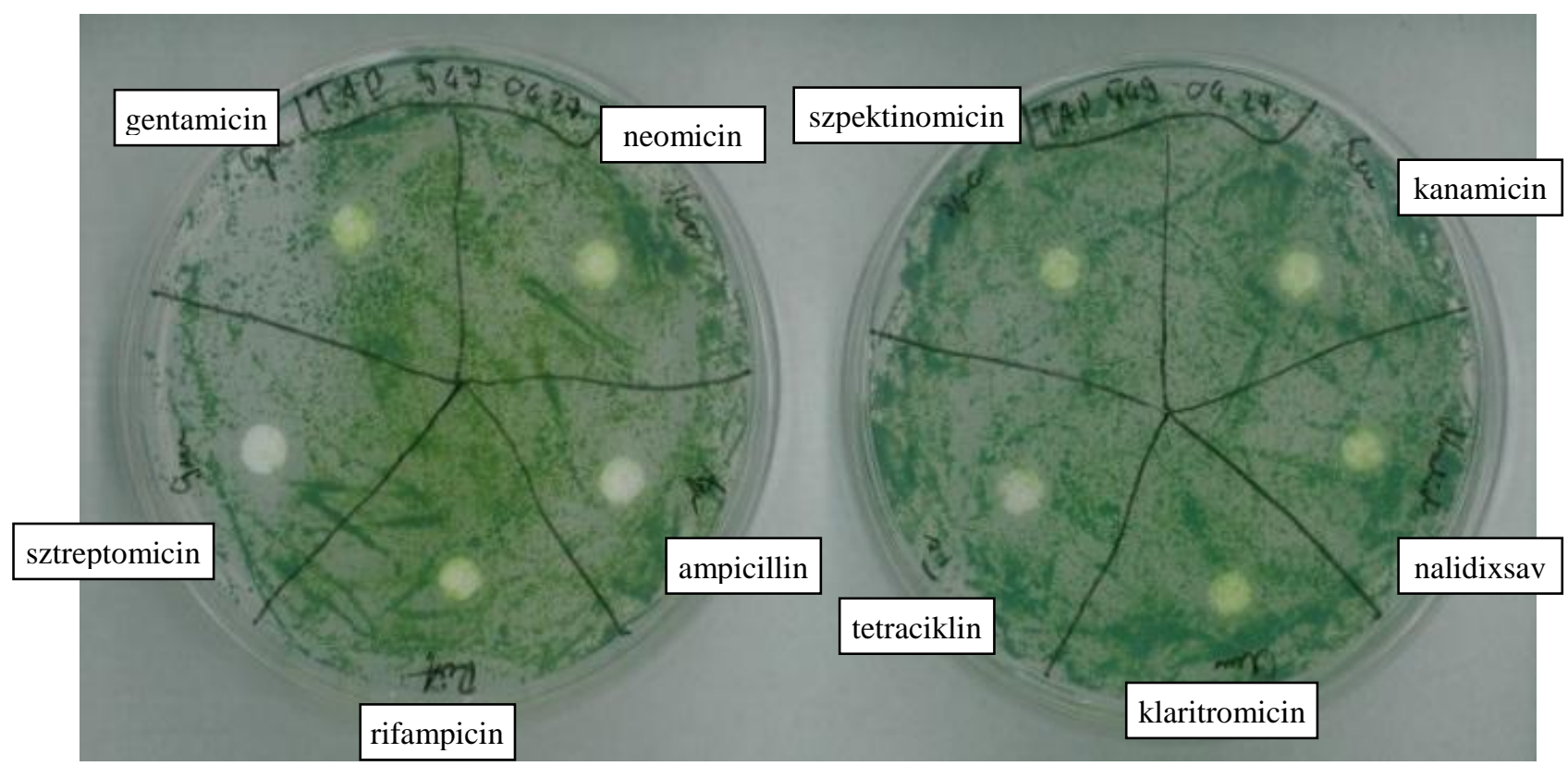

4. ábra: Antibiotikum teszt TAP lemezen növesztett Chlamydomonas sp. 549-el.

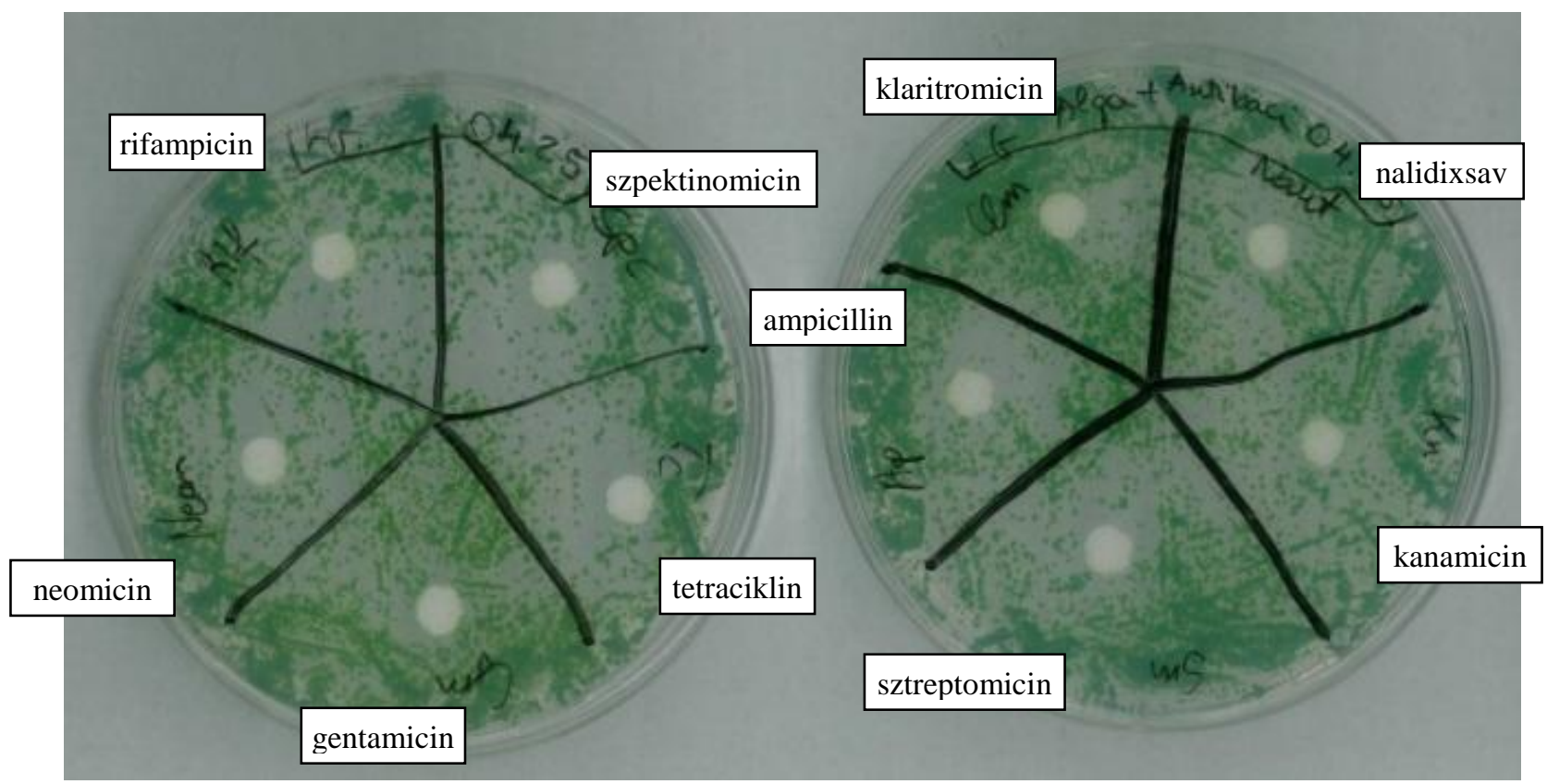

5. ábra: Antibiotikum teszt TP lemezen növesztett Chlamydomonas sp. 549-el.

A 10 antibiotikum közül csak a rifampicin bizonyult megfelelönek az alga hosszú távú monokultúraként történő fenntartásához. Kizárólag a rifampicin volt képes gátolni mindhárom baktérium törzs növekedését és ezzel együtt lehetővé tenni az algasejtek osztódását TAP és TP lemezeken egyaránt. A kísérletekhez szükséges alga biomasszát ezután rifampicinnel (50 $\mu \mathrm{g} / \mathrm{mL}$ ) kiegészített 120 x 120 mm-es TP lemezeken növesztve állítottuk elő. 


\subsubsection{Természetes bakteriális partnerek hatása az alga biomassza növekedésére}

Az eredeti kevert kultúra természetes partnereinek szétválasztása után lehetővé vált az egyedi baktérium törzsek jelenlétének vizsgálata az alga hidrogéntermelésére nézve. Minden egyes baktérium törzset LB lemezen növesztettünk fel, majd törzsoldatokat létrehozva TAP tápoldatba oltottuk őket, amelyekből a mért OD értékek alapján olyan hígított baktérium kultúrákat készítettünk a 40 mL-es szérumüvegekben, amelyeknek a 600 nm-en mért optikai denzitása 0.5 volt. Az általunk preferált 0.5-ös optikai denzitást előzetes kísérleteink eredményei alapján választottuk. Az alga kultúra esetében hasonlóan jártunk el. Itt az előzőekben leírt rifampicint tartalmazó TP lemezeken felnövesztett, axénikus algából készítettünk TAP tápoldatba leoltva alga törzsoldatot. Ebből a tömény kultúrából hígítottunk a kísérletek elvégzéséhez olyan töménységü alga kultúrákat, amelyek 750 nm-en mért optikai denzitása 0.7 volt. A vegyes alga-baktérium kultúrák mellett, kontrollként tiszta alga kultúrát is használtunk, és ennek sejtszámához viszonyítottuk a vegyes kultúrák alga sejtszámát. A méréshez minden nap $50 \mu \mathrm{L}$ mintát vettünk, amelyből $10 \mu \mathrm{L}-\mathrm{t}$ vittünk fel a Bürker-kamrára. Mindegyik kultúrában 4 napon keresztül folyamatos volt a sejtosztódás, majd a negyedik nap után az alga sejtszámnövekedés megállt és stagnálást mutatott. Az értékek összehasonlításához a negyedik napon regisztrált sejtszám adatokat használtuk fel: Chlamydomonas sp. 549: $414 * 10^{4}$ sejt / $\mu \mathrm{L}$, Chlamydomonas sp. 549 - Rhodococcus sp.: $498^{*} 10^{4}$ sejt / $\mu \mathrm{L}$, Chlamydomonas sp. 549 - Brevundimonas sp.: $432 * 10^{4}$ sejt / $\mu \mathrm{L}$, Chlamydomonas sp. 549 - Leifsonia sp.: $376^{*} 10^{4}$ sejt / $\mu \mathrm{L}$. 


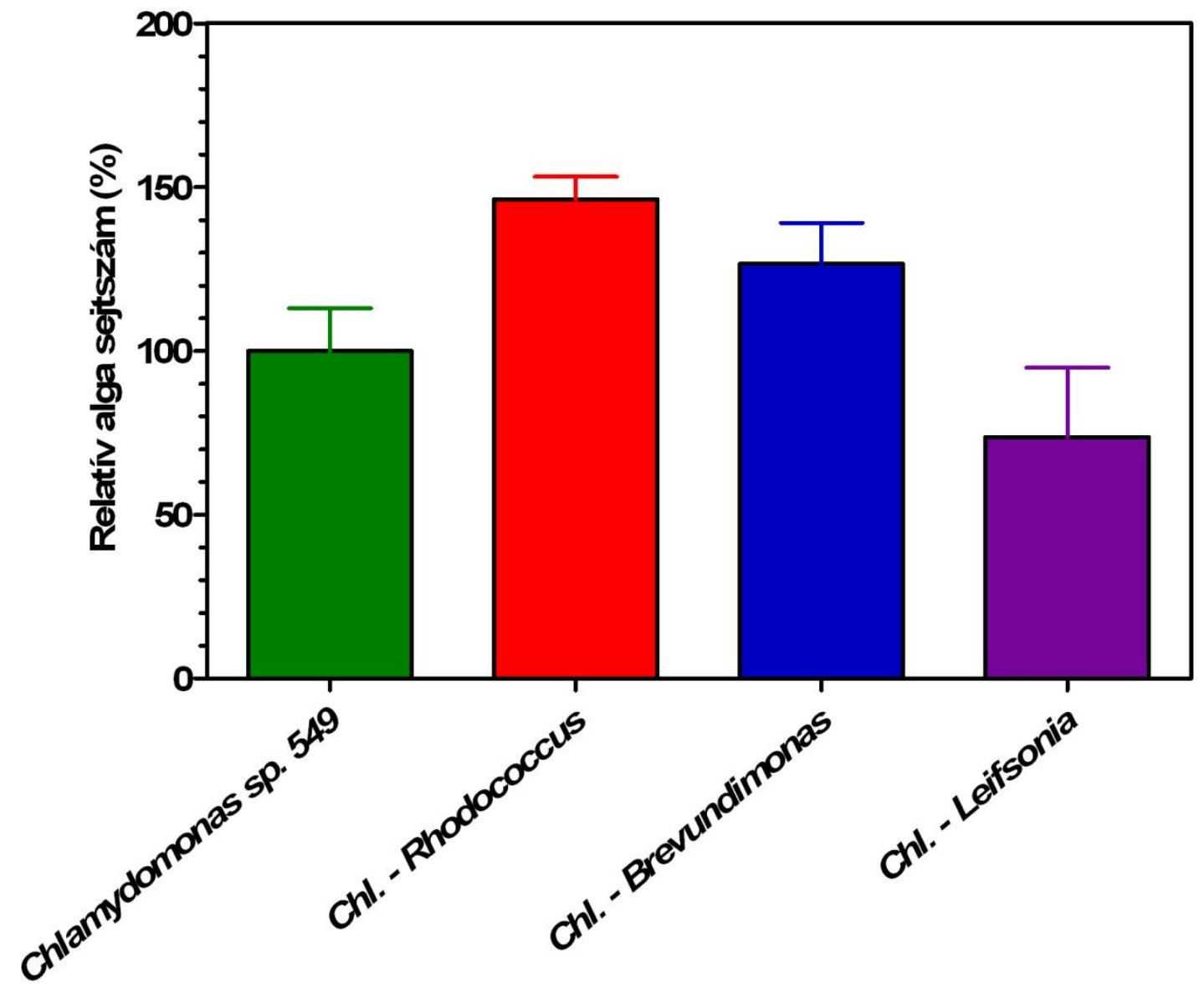

6. ábra: Relatív alga sejtszámok a negyedik napon a tiszta Chlamydomonas sp. 549 és a kevert alga-baktérium kultúrákban. A kísérlethez kultúránként három párhuzamos biológiai mintát használtunk és mindegyiken három sejtszámlálást végeztünk. A kapott adatokból átlagot és szórást számoltunk.

A kapott értékek összehasonlításához a különbözö sejtszámokat százalékosan adtuk meg (6. ábra). Ehhez a tiszta Chlamydomonas sp. 549 kultúra sejtszámát vettük alapul, amit 100\%-ként tüntettünk fel a 6. ábrán. A Chlamydomonas sp. 549 - Rhodococcus sp. és a Chlamydomonas sp. 549 - Brevundimonas sp. kevert kultúrákban az alga partner sejtszáma gyorsabb növekedést, míg a Chlamydomonas sp. 549 - Leifsonia sp. kevert kultúra alga sejtszáma lassabb növekedést mutatott a tiszta alga kultúra sejtszámához viszonyítva. A Rhodococcus sp. hozzáadásával 46\%-kal, míg a Brevundimonas sp. mellett 26\%-kal nagyobb volt az alga sejtszáma. A Leifsonia mellett viszont 27\%-kal alacsonyabb volt az alga sejtszám, mint a tiszta alga kultúrában. Az eredmények alapján az alga sejtszám növekedést leginkább a Rhodococcus sp. segítette elö. 


\subsection{Biohidrogéntermelés vizsgálatok}

\subsubsection{Természetes bakteriális partnerek hatása az alga hidrogéntermelésére}

Az alga mellett azonosított három bakteriális partner közül a hidrogéntermelés vizsgálatára legalkalmasabb kiválasztásához, megvizsgáltuk a három bakteriális törzs hatását az alga hidrogéntermelésére nézve. Ezekhez a mérésekhez, valamint a későbbi hidrogénmérések során is TAP tápoldatot és $40 \mathrm{~mL}$-es légmentesen zárható szérum üvegeket használtunk. Ezekben raktuk össze a $35 \mathrm{~mL}$ végtérfogatú kevert alga-baktérium folyadékkultúrákat. A fényen történő inkubáció során termelődött hidrogén az $5 \mathrm{~mL}-\mathrm{es}$ légtérben gyült össze. A légtérben felhalmozódott gázok méréséhez légzáró fecskendőt használtunk. $50 \mu \mathrm{L}$ gázmintát használtunk a gázkromatográfiás mérésekhez.

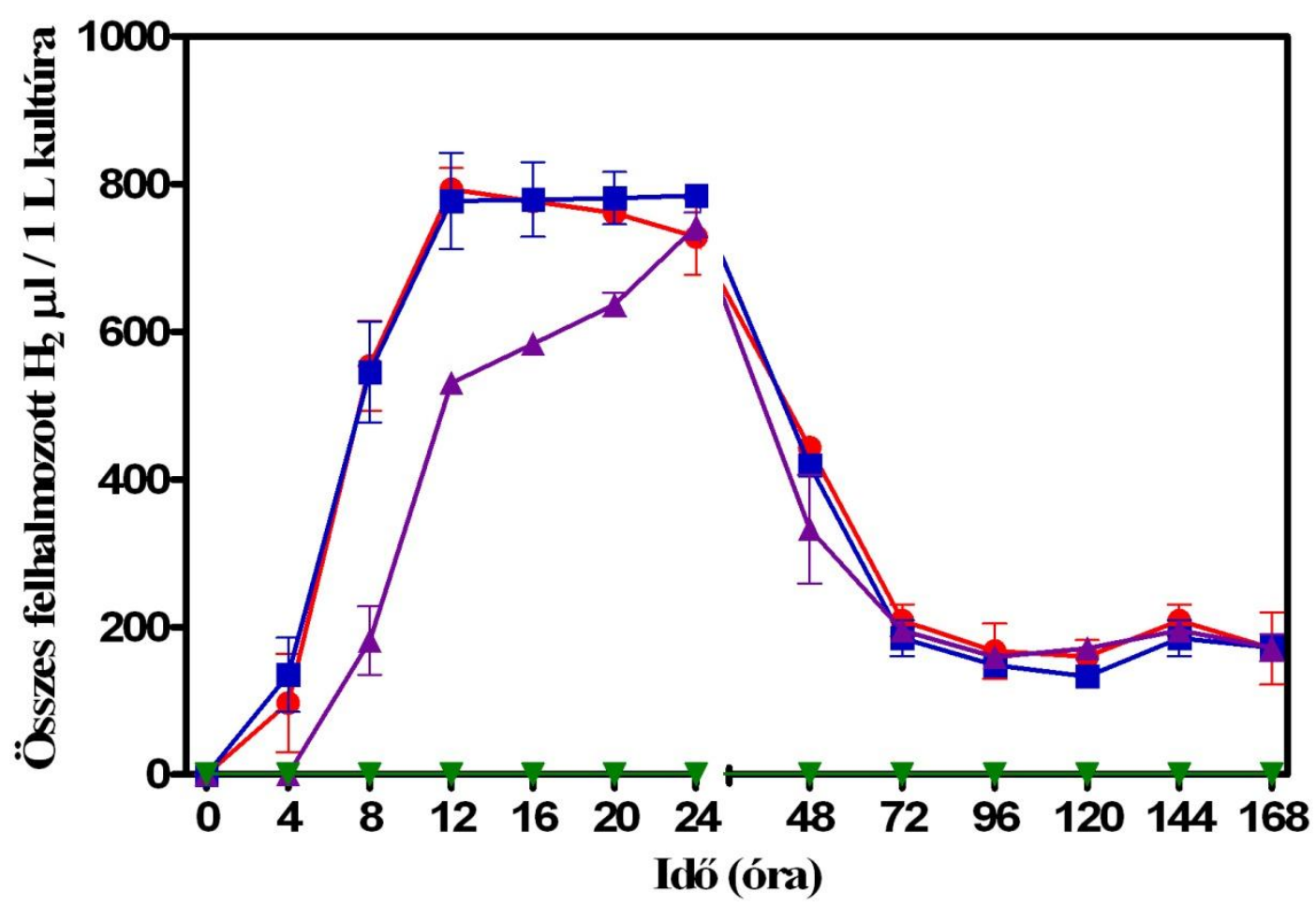

7. ábra: A három bakteriális partner hidrogéntermelésre gyakorolt hatásának összehasonlítása. A tiszta Chlamydomonas sp. 549 (zöld fordított háromszög) kultúra nem termelt hidrogént. Ezzel szemben a kevert, Rhodococcus-t (piros kör), Brevundimonas-t (kék négyzet) és Leifsonia-t (lila háromszög) egyenként tartalmazó algakultúrák közül a Brevundimonas-t és Rhodococcus-t tartalmazó kultúrák termelték a legtöbb hidrogént egységnyi idő alatt. A kísérlethez kultúránként három párhuzamos biológiai mintát 
használtunk és mindegyiken három mérést végeztünk. A kapott adatokból átlagot és szórást számoltunk.

Az eredményekből jól látszik, hogy a tiszta baktérium és a tiszta Chlamydomonas sp. 549 kultúrák önmagukban nem termeltek hidrogént TAP tápoldatban (7. ábra). Ezzel szemben mindegyik kevert alga-baktérium kultúra képes volt hidrogént előállítani. Általánosan elmondható, hogy a hidrogéntermelés egy adott légtérbeli hidrogén koncentráció eléréséig müködött, majd az első nap folyamán a gátló hatású koncentráció elérése után abbamaradt. A különböző természetes bakteriális partnerek hatására az alga által termelt összes hidrogén mennyiségek között az eltérés minimális volt, különbségeket leginkább a hidrogéntermelés sebességében figyeltünk meg a különböző konzorciumok között. A termelés leállása után, feltételezéseink szerint, mindkét konzorciumot alkotó partner (alga és baktérium) hidrogént újrahasznosító müködésének köszönhetően a légtérben felgyülemlett hidrogén mennyisége a harmadik napig fokozatosan csökkent, majd innentől kezdve nem változott.

\subsubsection{Az alga-baktérium arányok változtatásának hatása a hidrogéntermelésre}

A hidrogéntermelés szempontjából kiemelkedően fontos meghatározni a hidrogéntermelő kultúra biomasszájának alga és baktérium arányát. A legmegfelelőbb arány kiválasztásával minimalizálni lehet a szükséges biomassza mennyiségeket és maximalizálni az alga által megtermelt hidrogén mennyiségét. A 600 nm-en fixen 0.5-re beállított optikai denzitású Rhodococcus kultúra mellett csökkentettük a Chlamydomonas sp. 549 kultúra 750 nm-en 0.7-re beállított optikai denzitásához tartozó biomassza mennyiségét $20-20$ százalékponttal a kezdeti $100 \%$-hoz képest egészen $20 \%$-ig. Ugyanezt végrehajtottuk a konzorcium baktérium tagjával is (Rhodococcus sp.-vel), fix értéken tartva a Chlamydomonas sp. 549 mennyiségét.

A csökkenő alga biomassza mellett a megtermelt hidrogén mennyisége állandó maradt, viszont a termelés végpontja a biomassza csökkenésével arányosan időben fokozatosan eltolódott (8. ábra). Ezzel egybevágóan szintén eltolódást figyeltünk meg a kultúrák légterének oxigénszint változása során (9. ábra). A kísérletet megismételtük az alga biomassza növelésével. Ebben az esetben sem kaptunk magasabb hidrogén mennyiségeket. Minél több algát tartalmazott a minta, annál hamarabb érte el a maximálisan megtermelt hidrogén mennyiséget. A gyorsabb maximális érték elérése után a hidrogén felhasználása is 
elöbb indult el. Az oxigénszint változásban is gyorsulást figyeltünk meg, a kultúrák légterében a biomassza mennyiségével arányosan az oxigénszint intenzív növekedése már a második nap előtt megindult.

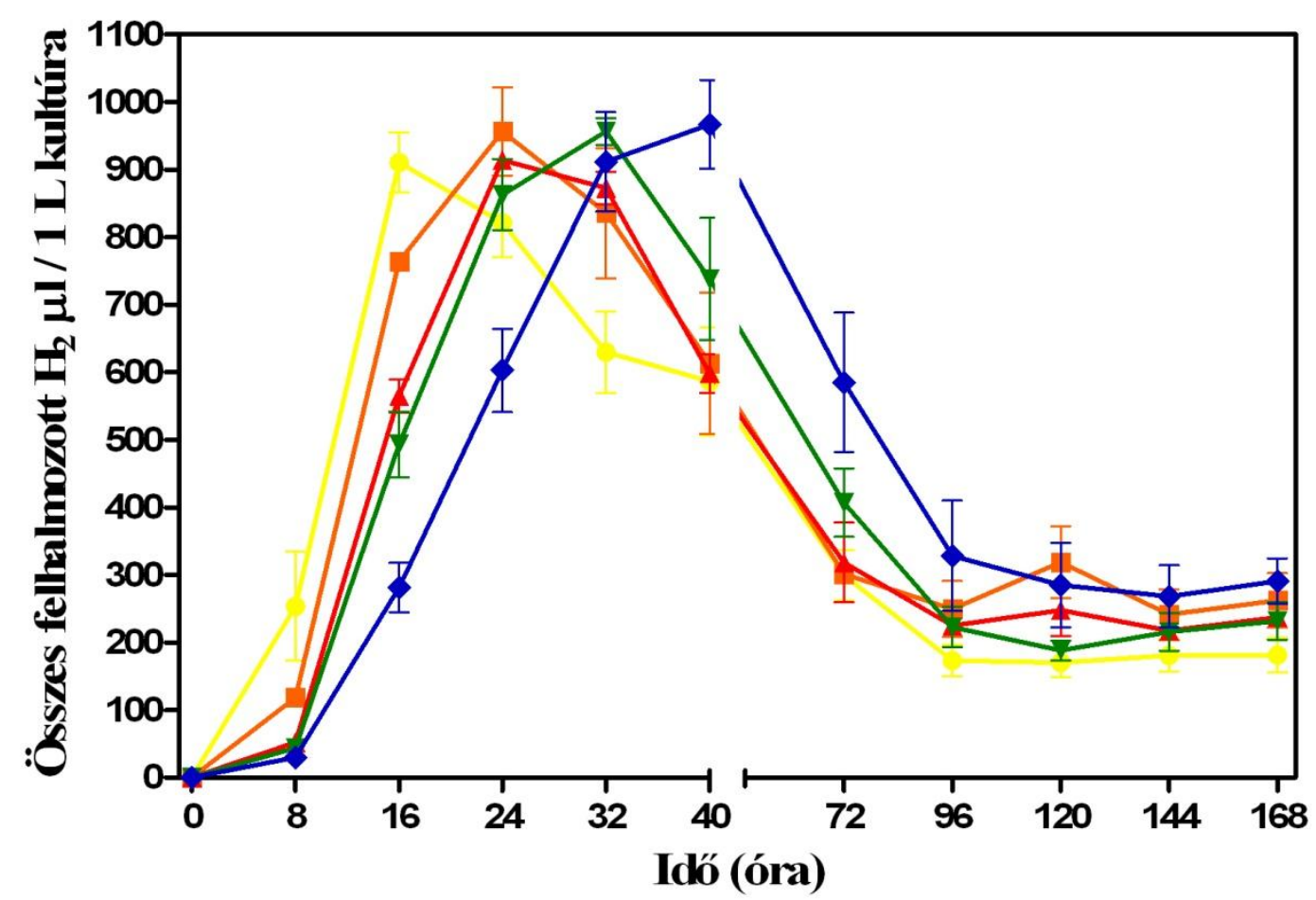

8. ábra: Vegyes kultúrák hidrogéntermelésének változása csökkenő Chlamydomonas sp. 549 biomassza mennyiségek mellett. A Rhodococcus mennyisége 100\%-on maradt, míg az alga mennyiségét 100\%-ról (sárga kör) 80\%-ra (narancssárga négyzet), 60\%-ra (piros háromszög), 40\%-ra (zöld fordított háromszög) és 20\%-ra (kék rombusz) csökkentettük. A kísérlethez kultúránként három párhuzamos biológiai mintát használtunk és mindegyiken három mérést végeztünk. A kapott adatokból átlagot és szórást számoltunk. 


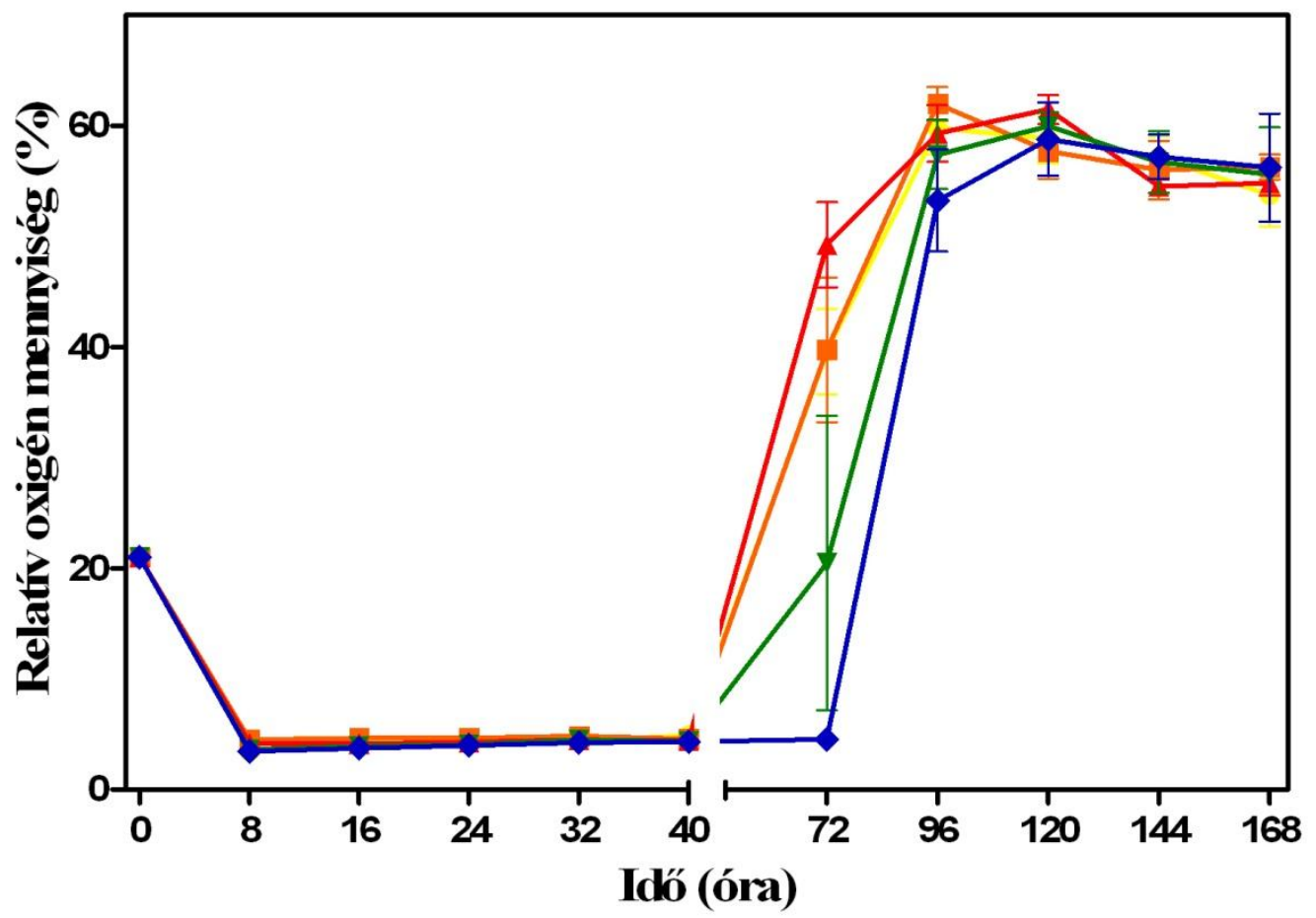

9. ábra: Vegyes kultúrák oxigénszintjének változása csökkenő Chlamydomonas sp. 549 biomassza mennyiségek mellett. A Rhodococcus mennyisége 100\%-on maradt, míg az alga mennyiségét 100\%-ról (sárga kör) 80\%-ra (narancssárga négyzet), 60\%-ra (piros háromszög), 40\%-ra (zöld fordított háromszög) és 20\%-ra (kék rombusz) csökkentettük. A kísérlethez kultúránként három párhuzamos biológiai mintát használtunk és mindegyiken három mérést végeztünk. A kapott adatokból átlagot és szórást számoltunk.

A bakteriális partner biomassza mennyiségének csökkenése az alga biomassza csökkenésének hatásával ellentétben jelentősen befolyásolta a maximális felgyülemlett hidrogén mennyiségét a kultúra légterében. A bakteriális biomassza csökkenésével párhuzamosan fokozatosan redukálódott a megtermelt hidrogén mennyiség (10. ábra), valamint lassult a légtér oxigénszintjének csökkenése (11. ábra). A lassabb anaerobizálódás időben későbbre tolta a hidrogéntermelés kezdeti időpontját (11. ábra), valamint a maximálisan megtermelt hidrogén csúcspontját (10. ábra). 


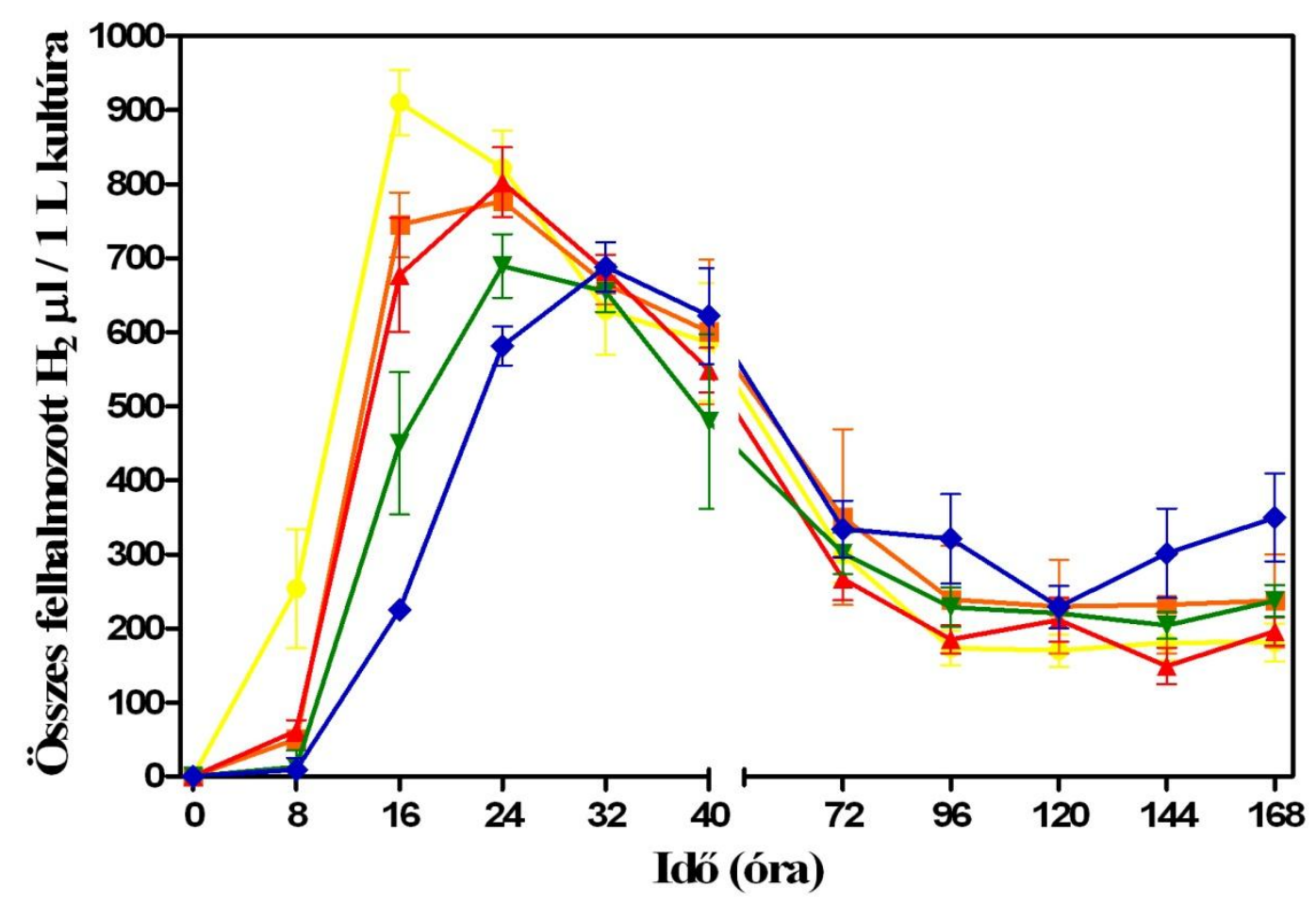

10. ábra: Vegyes kultúrák hidrogéntermelésének változása csökkenő Rhodococcus sp. biomassza mennyiségek mellett. A Chlamydomonas sp. 549 mennyisége 100\%-on maradt, míg a Rhodococcus mennyiségét 100\%-ról (sárga kör) 80\%-ra (narancssárga négyzet), 60\%ra (piros háromszög), 40\%-ra (zöld fordított háromszög) és 20\%-ra (kék rombusz) csökkentettük. A kísérlethez kultúránként három párhuzamos biológiai mintát használtunk és mindegyiken három mérést végeztünk. A kapott adatokból átlagot és szórást számoltunk. 


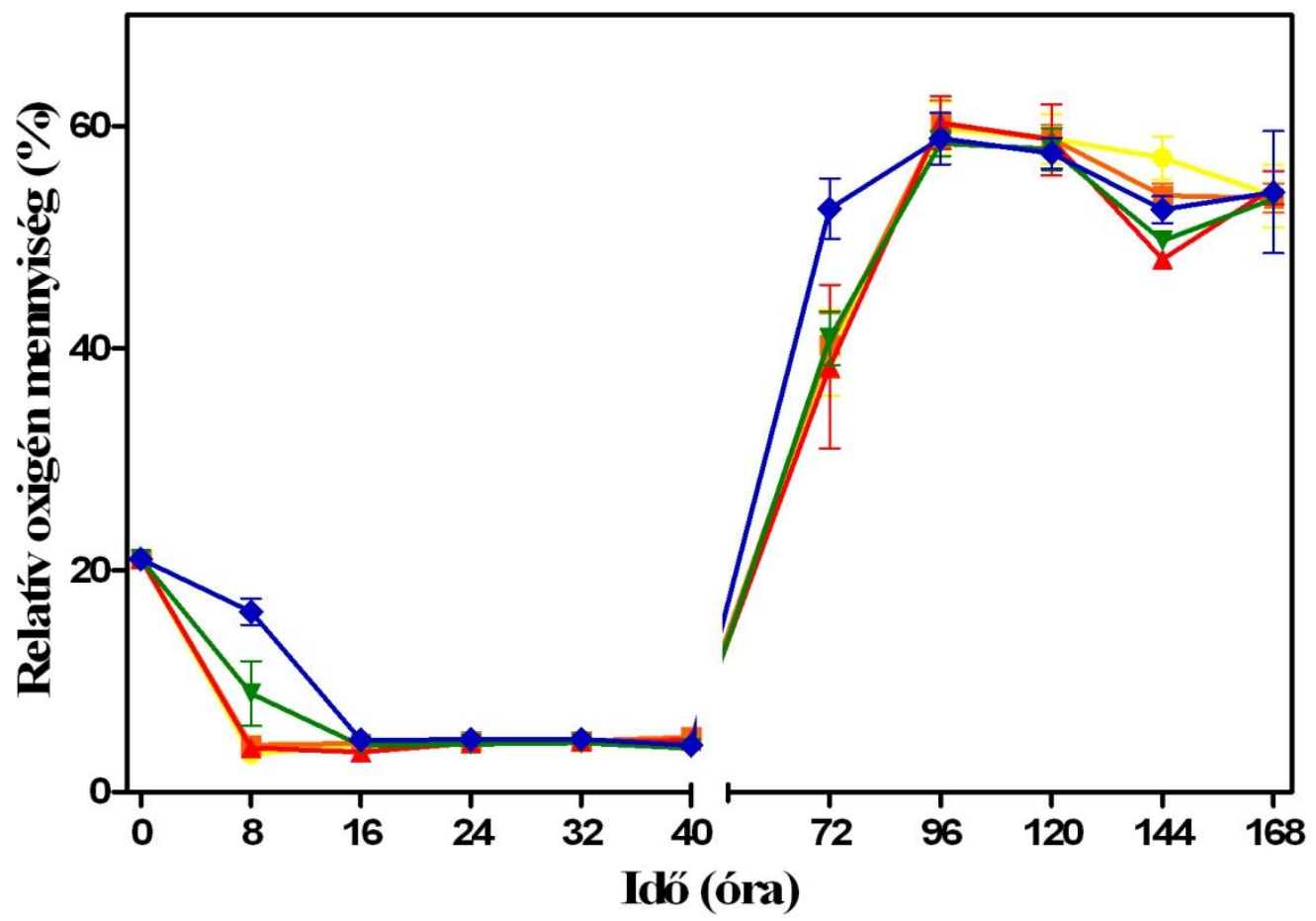

11. ábra: Vegyes kultúrák oxigénszintjének változása csökkenő Rhodococcus sp. biomassza mennyiségek mellett. A Chlamydomonas sp. 549 mennyisége 100\%-on maradt, míg a Rhodococcus mennyiségét 100\%-ról (sárga kör) 80\%-ra (narancssárga négyzet), 60\%-ra (piros háromszög), 40\%-ra (zöld fordított háromszög) és 20\%-ra (kék rombusz) csökkentettük. A kísérlethez kultúránként három párhuzamos biológiai mintát használtunk és mindegyiken három mérést végeztünk. A kapott adatokból átlagot és szórást számoltunk.

\subsubsection{Hidrogéntermelő partner meghatározása vad típusú és hidrogenáz deficiens baktérium törzsekkel}

Az alga-baktérium vegyes kultúrák hidrogéntermelése kapcsán felmerült a kérdés, hogy a konzorcium mely partnere képes közvetlenül a hidrogén elöállítására. A kérdés megválaszolásához egy olyan kísérletet terveztünk, amelyben két, a természetes bakteriális partnerektől függetlenül, mesterségesen az algakultúrához hozzáadott baktérium törzsek vad (Escherichia coli K12 és Ralstonia eutropha H16) és hidrogenáz deficiens (Escherichia coli $\Delta$ hypF és Ralstonia eutropha HF441) típusait alkalmaztuk. Elméletileg mind az alga, mind pedig a bakteriális partner képes megfelelő körülmények között a hidrogéntermelésre. A természetes konzorciumi partnerekként azonosított baktériumok mindegyike tartalmazott 
hidrogenáz enzimeket. A bakteriális partnerek mindegyikében megtalálható volt legalább egy NiFe hidrogenáz. A mutáns $R$. eutropha HF441 és $E$. coli $\Delta h y p F$ törzsekből hiányzik a NiFe hidrogenázok müködéséhez esszenciális $\mathrm{HypF}$ fehérje, melynek hiánya blokkolja a $\mathrm{NiFe}$ hidrogenázok bioszintézisét (Maier és mtsai. 1996). A $\triangle$ hypF mutáns törzsek alkalmazásával lehetőségünk nyílt nem csak a termelö partner/ek azonosítására, hanem a természetes partnerektől eltérö, mesterségesen hozzáadott baktérium törzsek alga hidrogéntermelésre gyakorolt hatásának elemzésére is. Feltételezéseink szerint, ha a bakteriális partnerek is részt vesznek a hidrogéntermelésben vagy a termelt hidrogén visszavételében, akkor a vad típusú baktérium törzseket tartalmazó vegyes kultúrák vagy több vagy kevesebb hidrogént állítanak elő, mint a $\triangle h y p F$ mutáns baktériumokat tartalmazó konzorciumok. A kapott eredmények alapján jól látszik, hogy a vad típusú baktérium törzseket tartalmazó kevert kultúrák nem termeltek többet a mutáns törzseket tartalmazó kultúráknál (12. ábra). A hidrogenáz deficiens E. coli $\triangle h y p F$-t tartalmazó vegyes kultúrák légterében szignifikánsan több hidrogént tudtunk detektálni, mint a vad típusú baktériumokat tartalmazó kevert kultúrák légterében. Mindegyik vegyes kultúra esetében a maximális akkumulálódott hidrogén időpontja megegyezett. A vegyes kultúráktól eltérően a tiszta baktérium kultúrák nem termeltek hidrogént (12. ábra). Ez alapján állítható, hogy a hidrogéntermelés folyamata kizárólag az alga partnerhez köthető.

Megfigyeltük ugyanakkor azt is, hogy a vegyes kultúrák légterében felhalmozódott hidrogén mennyiségéből a termelési fázist követő időszakban a hidrogenáz deficiens $E$. coli $\Delta h y p F$ és $R$. eutropha HF441 törzseket tartalmazó kultúrákban számottevően több maradt, mint a vad típusú $E$. coli K12 és $R$. eutropha H16 törzseket tartalmazó kultúrákban (12. ábra). Ez alapján feltételezzük, hogy a NiFe hidrogenázokat tartalmazó bakteriális törzsek a megtermelt hidrogén egy részét felhasználták. Megfigyeltük ezzel együtt azt is, hogy az aktív hidrogenázokkal nem rendelkezö $E$. coli $\triangle$ hypF és $R$. eutropha H16 bakteriális partnert tartalmazó kultúrák összes hidrogén mennyisége is csökkent a termelő fázis vége után. Mindez alapján úgy gondoljuk, hogy nem csak a vad típusú E. coli K12 és R. eutropha H16 bakteriális partnerek képesek felhasználni a megtermelt hidrogént, hanem az Chlamydomonas sp. 549 alga partner is.

A legmagasabb szintü hidrogéntermelést a hidrogenáz deficiens $E$. coli $\Delta h y p F$ törzs alkalmazása során figyeltük meg. Az eredményekből jól látszik, hogy a megfelelően megválasztott mesterségesen hozzáadott bakteriális törzsekkel nem csak a hidrogéntermelés 
indukálása, hanem további termelésnövekedés is elérhetö. A későbbi kísérletekhez kiváló tulajdonságai alapján az E. coli $\Delta h y p F$ törzset használtuk.

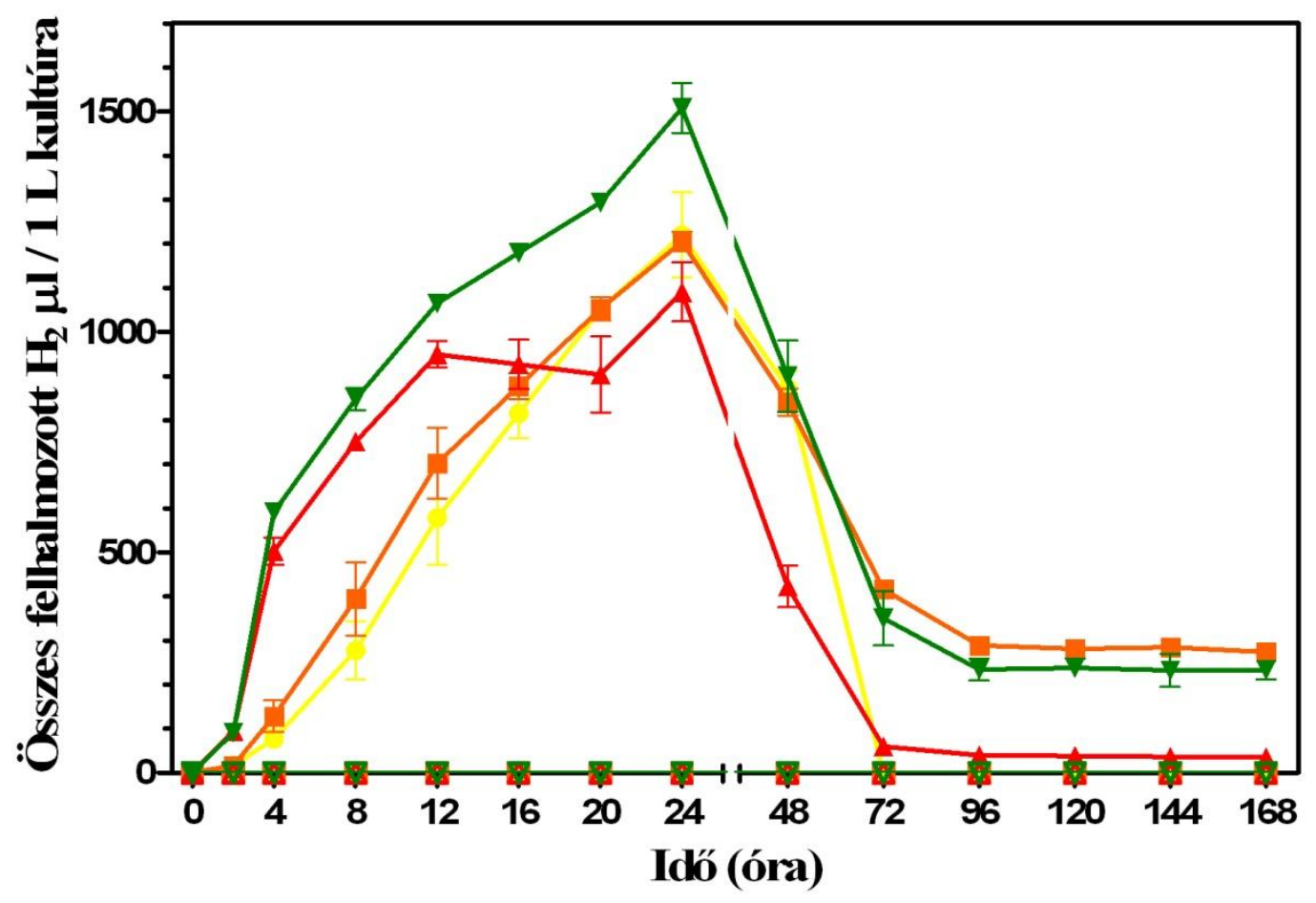

12. ábra: E. coli $\triangle h y p F$ és $R$. eutropha HF441 mutáns és vad törzseivel kiegészített Chlamydomonas sp. 549 kultúrák hidrogéntermelése. A Chlamydomonas sp. 549 kultúrához a R. eutropha H16 vad (citromsárga zárt kör), a R. eutropha HF441 mutáns (narancssárga zárt négyzet), az E. coli K12 vad (piros zárt háromszög) és az E. coli $\Delta$ hypF mutáns (zöld zárt fordított háromszög) törzseket adtuk hozzá. A tiszta $R$. eutropha H16 vad (citromsárga nyitott kör), a $R$. eutropha HF441 mutáns (narancssárga nyitott négyzet), az E. coli K12 vad (piros nyitott háromszög) és az E. coli $\triangle$ hypF mutáns (zöld nyitott fordított háromszög) kultúrák önmagukban nem termeltek hidrogént. A kísérlethez kultúránként három párhuzamos biológiai mintát használtunk és mindegyiken három mérést végeztünk. A kapott adatokból átlagot és szórást számoltunk. 


\subsubsection{Mutáns és vad típusú bakteriális partnerek hatásának vizsgálata a vegyes és tiszta kultúrák oxigénszint változására}

A R. eutropha és E. coli különböző törzseinek oxigénfogyasztó képességét vizsgáltuk a tiszta baktérium és kevert alga-baktérium kultúrákban. A kultúrák anaerobizálódása a kísérlet első 12 órájában ment végbe. Az ábrán jól láthatóan elkülönülnek a két törzs oxigénfogyasztási értékei (13. ábra). Az E. coli mutáns és vad típusát tartalmazó kultúrák légtere 4 óra alatt, míg a $R$. eutropha mutáns és vad típusát tartalmazó kultúrák légtere 12 óra alatt érte el a 4\% körüli oxigén értéket. Az oxigénfogyás különbségei a hidrogéntermelés kezdeti időpontjaiban is jól tükröződnek (12. ábra). Igaz a hidrogéntermelés kezdeti időpontjai között 2 óra, míg a légtér 4\%-os oxigénszint elérésében 8 óra a különbség. A $4 \%$-os oxigénszint a vegyes kultúrákban két napig maradt stabil a légtérben. A kevert kultúrákban a második nap után intenzív oxigénfejlődés indult meg. Ezalatt a tiszta baktérium kultúrák légterében a relatív oxigénszint alacsony maradt. A hidrogéntermelés szempontjából a légtérben lévő oxigénszint növekedése gátló hatású. Az légtér oxigén szintjének növekedésével párhuzamosan a folyadék fázis oxigén tartalma is emelkedésnek indult (16. ábra), amely gátolta a további hidrogéntermelést. Az oxigén mennyisége a negyedik napra elérte a légtér térfogatának $60 \%$-át, amely nem változott jelentős mértékben a kísérlet hátralevő részében.

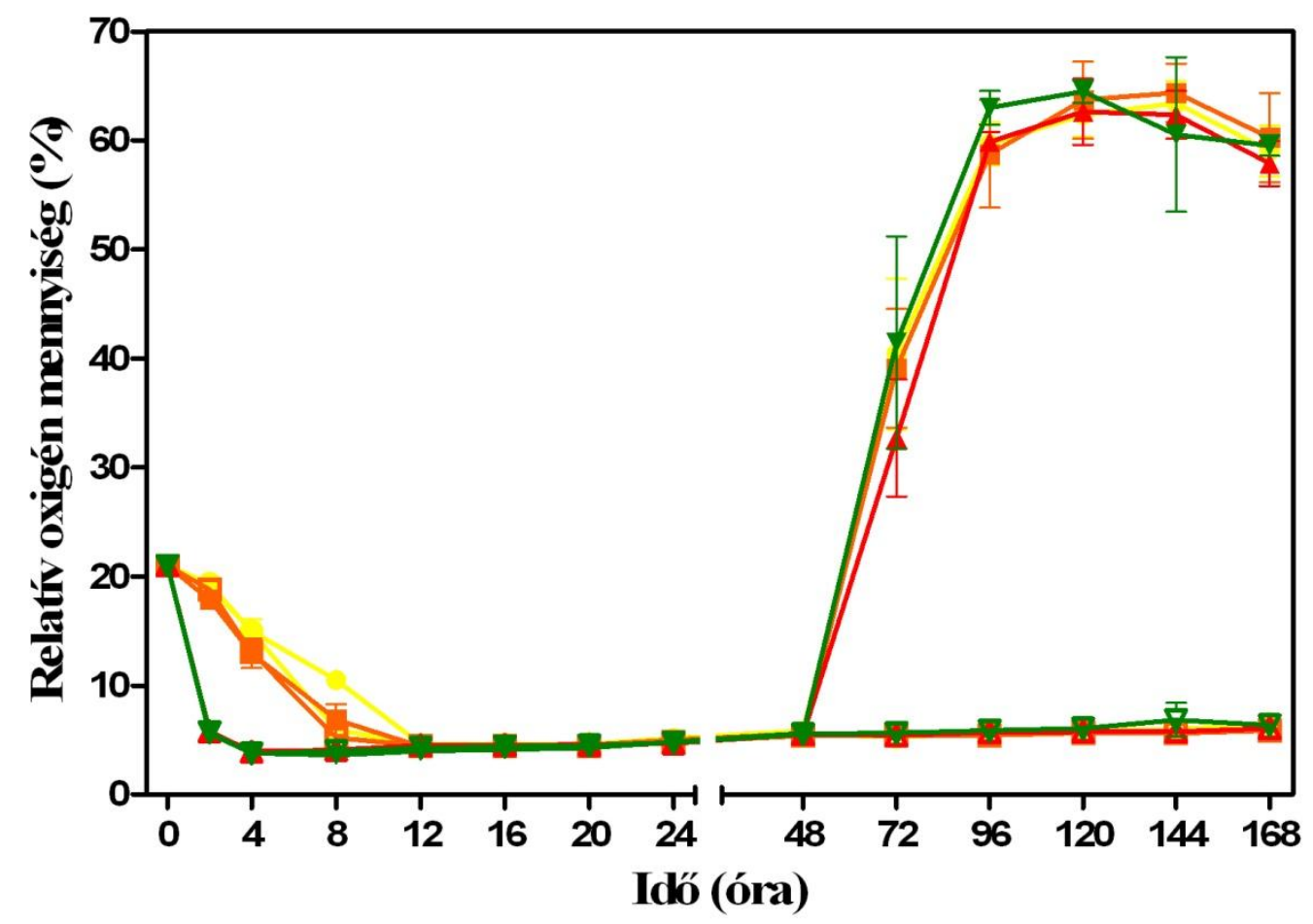


13. ábra: Tiszta baktérium kultúrák, és az E. coli és $R$. eutropha mutáns és vad törzseivel kiegészített Chlamydomonas sp. 549 kultúrák oxigénszint változása. A tiszta $R$. eutropha H16 vad (citromsárga nyitott kör), R. eutropha HF441 mutáns (narancssárga nyitott négyzet), E. coli $\mathrm{K} 12 \mathrm{vad}$ (piros nyitott háromszög) és E. coli $\Delta$ hypF mutáns (zöld nyitott fordított háromszög) kultúrák mellett, a Chlamydomonas sp. 549 kultúrához a R. eutropha H16 vad (citromsárga zárt kör), a $R$. eutropha HF441 mutáns (narancssárga zárt négyzet), az E. coli K12 vad (piros zárt háromszög) és az E. coli $\triangle h y p F$ mutáns (zöld zárt fordított háromszög) törzseket adtuk hozzá. Az E. coli mutáns és vad törzseivel négy óra alatt, míg a $R$. eutropha mutáns és vad törzseivel nyolc óra alatt csökkent le az oxigén szint a tiszta és a vegyes kultúrákban. A Chlamydomonas sp. 549-et tartalmazó kultúrák oxigén szintje két nap után növekedésnek indult, mialatt a tiszta baktérium kultúrák oxigén szintje nem változott. A kísérlethez kultúránként három párhuzamos biológiai mintát használtunk és mindegyiken három mérést végeztünk. A kapott adatokból átlagot és szórást számoltunk.

\subsubsection{Hidrogéntermelés Chlamydomonas sp. 549 és $C h$. reinhardtii cc124 kevert alga- baktérium törzsekkel}

A Ch. reinhardtii cc124 egy olyan Chlamydomonas törzs, amelyet számos hidrogéntermeléssel kapcsolatos kísérletben alkalmaztak. Ezért a Chlamydomonas sp. 549 hidrogéntermelő tulajdonságainak vizsgálatához kontroll törzsnek ezt az algát választottuk. Az összehasonlító mérések során jól látható különbségeket tapasztaltunk meg a kétféle algatörzs között. Az első nap folyamán a C. reinhardtii cc124 - E. coli $\Delta h y p F$ vegyes kultúra megközelítőleg hatszor $\left(5800.54 \pm 65.73 \mu \mathrm{L} \mathrm{L}^{-1}\right)$ nagyobb mennyiségü hidrogént halmozott fel a légterében a Chlamydomonas sp. 549 - E. coli $\Delta$ hypF vegyes kultúrához $(1196.06 \pm 4.42$

$\mu \mathrm{L} \mathrm{L}^{-1}$ ) viszonyítva. A hidrogéntermelés gyorsasága a $C$. reinhardtii cc124 esetében $241.68 \pm$ $2.73 \mu \mathrm{L} \mathrm{L}^{-1} \mathrm{~h}^{-1}$, míg a Chlamydomonas sp. 549 esetében $49.83 \pm 0.18 \mu \mathrm{L} \mathrm{L}^{-1} \mathrm{~h}^{-1}$ volt. Az első napot követően a hidrogéntermelés abbamaradt (14. ábra). Ezután azt tapasztaltuk, hogy a kevert kultúrák alga partnerei felhasználták a légtérben felhalmozott hidrogén egy részét. A $C$. reinhardtii cc124 esetében ez egy, míg a Chlamydomonas sp 549 esetében két nap alatt történt meg. A C. reinhardtii cc124 légterében a második naptól kezdve a hidrogén felhalmozódás újraindult. A Chlamydomonas sp. 549 kevert kultúrájának légterében a hidrogénkoncentráció a mérések végéig állandó maradt. 


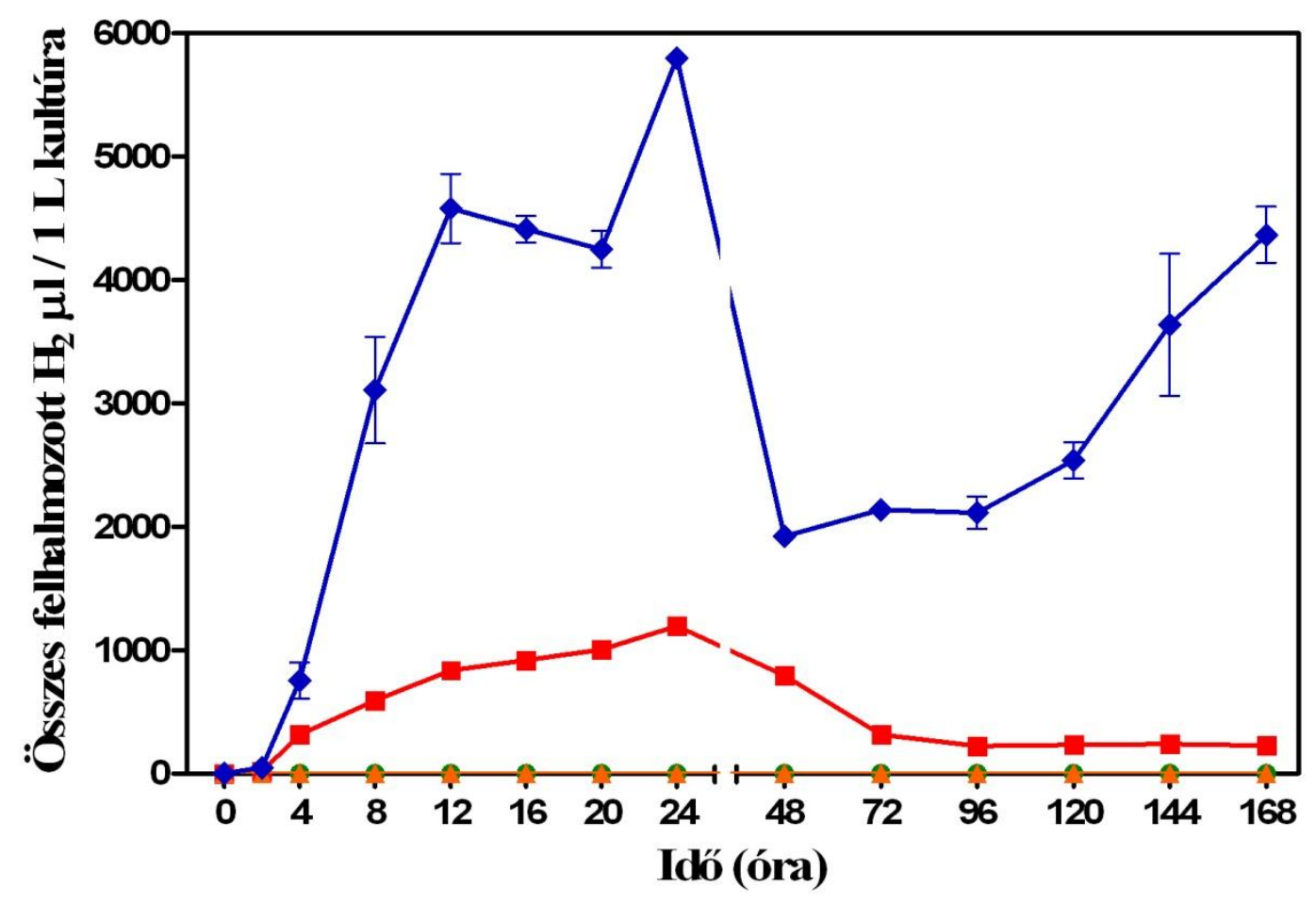

14. ábra: Chlamydomonas sp. 549 és Ch. reinhardtii cc124 E. coli $\Delta$ hypF-el kevert kultúráinak hidrogéntermelése. A Chlamydomonas sp. 549 - E. coli $\Delta h y p F$ vegyes kultúra $1196.06 \pm 4.42 \mu \mathrm{L} \mathrm{L}^{-1}$ (piros zárt négyzet), a C. reinhardtii cc124 - E. coli $\Delta$ hypF vegyes kultúra $5800.54 \pm 65.73 \mu \mathrm{L} \mathrm{L}^{-1}$ (kék zárt rombusz) hidrogént termelt, míg a tiszta Chlamydomonas sp. 549 (zöld zárt kör) és E. coli $\Delta$ hypF (narancssárga zárt háromszög) kultúrák nem termeltek hidrogént. A kísérlethez kultúránként három párhuzamos biológiai mintát használtunk és mindegyiken három mérést végeztünk. A kapott adatokból átlagot és szórást számoltunk.

\subsubsection{Oxigénszint változás a vegyes és tiszta alga és baktérium kultúrákban}

Az oxigénszint változásokat először a kultúrák légterében vizsgáltuk. A kevert $C$. reinhardtii cc124 - E. coli $\Delta$ hypF és a Chlamydomonas sp. 549 - E. coli $\Delta$ hypF kevert, illetve a tiszta Chlamydomonas sp. 549 és E. coli $\Delta$ hypF kultúrák összehasonlítása során megfigyeltük, hogy a vártnak megfelelően a tiszta Chlamydomonas sp. 549 kivételével mindegyik E. coli $\triangle h y p F$-et tartalmazó kultúra légterében az oxigénszint 3\% körüli értékre lecsökkent (15. ábra). A tiszta alga légterében az oxigénszint az első két nap során nem 
mutatott jelentős változást, a szintje a kiindulási $21 \%$ körül ingadozott. A második nap után a tiszta Chlamydomonas sp. 549 és a kevert Chlamydomonas sp. 549 - E. coli $\Delta$ hypF kultúrák oxigén szintje gyors emelkedésnek indult. A két kultúra légterének oxigén szintje $60 \%$ körül stabilizálódott. A tiszta E. coli $\triangle h y p F$ és a $C$. reinhardtii cc124 - E. coli $\triangle$ hypF kevert kultúrák relatív oxigénszintje a 7 napos kísérlet során végig 2 - 7 \%-on maradt.

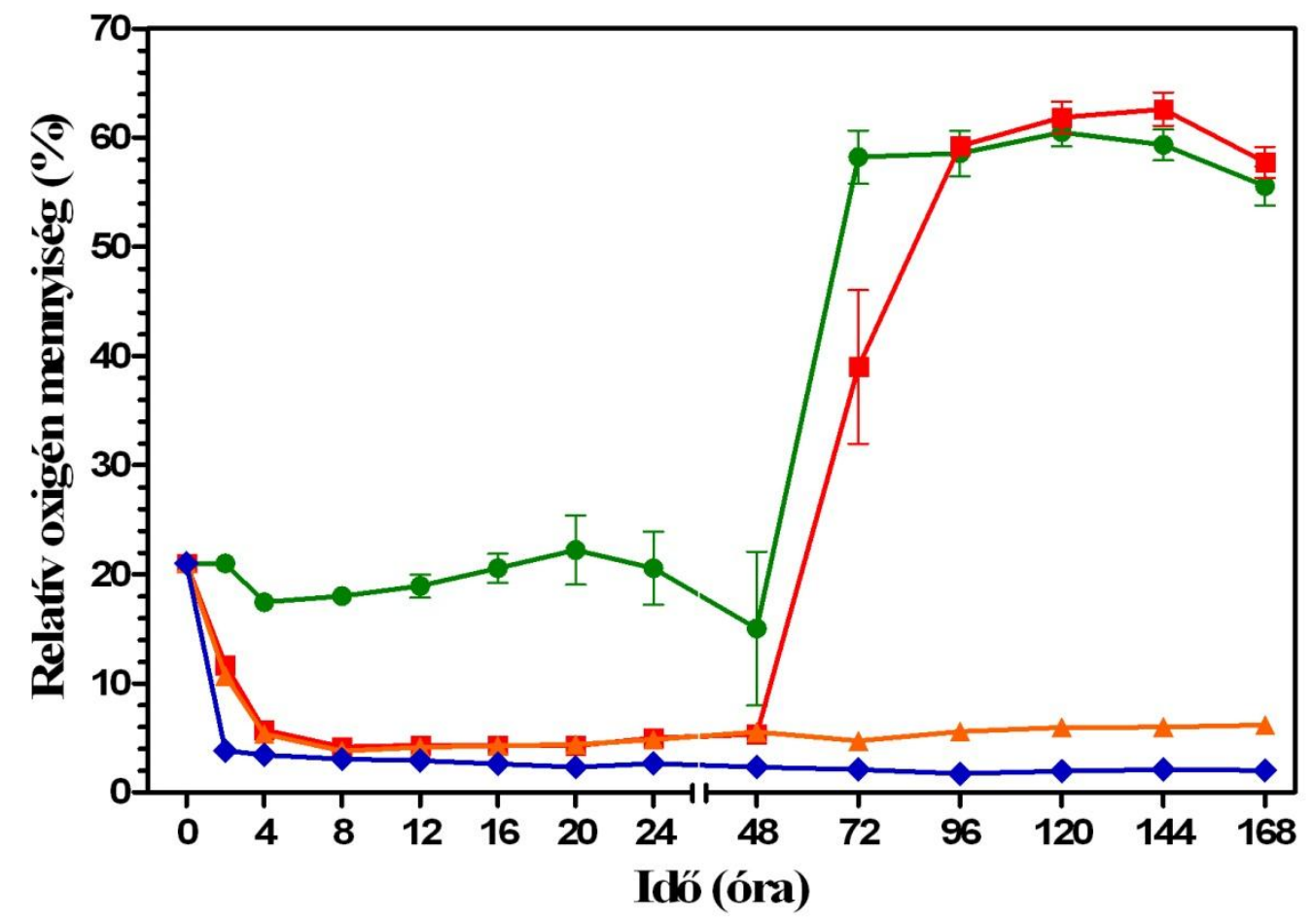

15. ábra: Chlamydomonas sp. 549 (piros zárt négyzet) és Ch. reinhardtii cc124 E. coli $\Delta h y p F$-el (kék zárt rombusz) kevert kultúráinak és a tiszta Chlamydomonas sp. 549 (zöld zárt kör) E. coli $\triangle h y p F$ (narancssárga zárt háromszög) kultúrák légterében végbemenő oxigénszint változások. A kísérlethez kultúránként három párhuzamos biológiai mintát használtunk és mindegyiken három mérést végeztünk. A kapott adatokból átlagot és szórást számoltunk.

\subsubsection{Az oldott oxigénszint változása kevert és tiszta kultúrákban}

A gázkromatográfiás méréseink során képet kaptunk arról, hogyan változott az oxigénszint a zárt kultúrák légterében. A hidrogéntermelés azonban a folyadékfázisban történik, azaz az oldott oxigénszint mérése elengedhetetlen. Az egyes kultúrák oldott oxigénszint méréseihez a folyadékfázisban oldott állapotban lévő oxigén detektálására 
alkalmas elektródot használtunk. Kiindulási oldott oxigén koncentrációként $257 \mu \mathrm{mol} \mathrm{L} \mathrm{L}^{-1}-\mathrm{t}$ mértünk. A tiszta E. coli $\triangle$ hypF és a kevert Chlamydomonas sp. 549 - E. coli $\Delta$ hypF kultúrák oldott oxigén koncentrációja 3-4 óra alatt 1-2 $\mu \mathrm{mol} \mathrm{L}{ }^{-1}$-re csökkent a kiindulási értékről. A tiszta alga kultúrákban az oldott oxigén koncentrációja enyhe emelkedésnek indult a kiindulási értékről, és néhány óra után $650 \pm 100 \mu \mathrm{mol} \mathrm{L}^{-1}$ érték körül stabilizálódott. A második nap után az alga oxigéntermelése a tiszta Chlamydomonas sp. 549 és a kevert Chlamydomonas sp. 549 és E. coli $\triangle$ hypF kultúrákban 24-36 órán át magasabb ütemü volt és a folyadékfázisban az oxigén szint $1300-1600 \mu \mathrm{mol} \mathrm{L}{ }^{-1}$-ig emelkedett. A tiszta $E$. coli $\Delta$ hypF kultúrában az oldott oxigén koncentráció a kísérlet végéig $1-2 \mu \mathrm{mol} \mathrm{L}^{-1}$ maradt. A zárt kultúra oxigén tartalma alapvetően meghatározza a hidrogenázok aktivitását, ezért az oxigén koncentráció gyors emelkedésének megértéséhez a későbbiekben analitikai vizsgálatokat végeztünk a TAP tápoldat ecetsav koncentráció változására nézve.

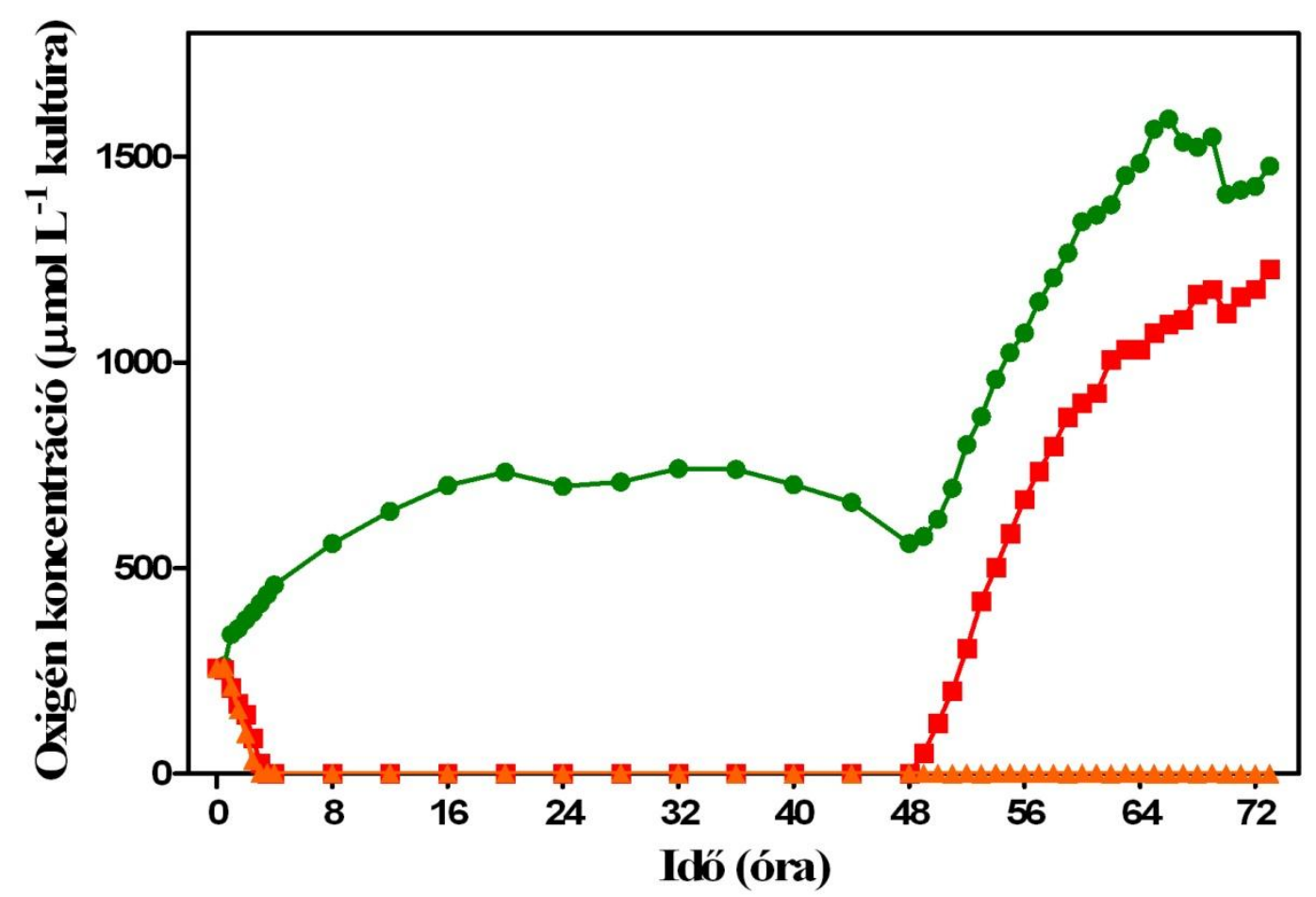

16. ábra: Chlamydomonas sp. 549 (piros zárt négyzet) kevert kultúrának, valamint a tiszta Chlamydomonas sp. 549 (zöld zárt kör) és E. coli $\Delta$ hypF (narancssárga zárt háromszög) kultúráknak a folyadék fázisban végbemenő oxigénszint változásai. A kísérlethez kultúránként egy biológiai mintát használtunk és mindegyiken egy mérést végeztünk. 


\subsection{A kultúrák folyadékfázisának analitikai vizsgálata}

\subsubsection{Ecetsavfogyás tiszta alga és kevert alga-baktérium kultúrákban}

A hidrogenázok aktiválódásához elengedhetetlenül fontos a kultúrák alacsony oxigén szintje. Az alga-baktérium kultúrák oxigénfogyasztásában a bakteriális légzés mellett fontos szerepe van az alga partner sejtlégzésének is. Az ecetsav olyan szénforrás az alga számára, amelyet megvilágítás mellett képes felhasználni az anyagcsere folyamataihoz. Hatására a sejtlégzés felgyorsul, így a légtérben, illetve a folyadékfázisban lévő oxigén gyorsabban használódik el. A zárt rendszer anaerobizálódása elősegíti a hidrogenázok működését és a hidrogéntermelést. A tiszta Chlamydomonas sp. 549 és a kevert Chlamydomonas sp. $549-E$. coli $\triangle h y p F$ kultúrák ecetsav felhasználásának tanulmányozásához, mivel az analitikai minták vizsgálatához $5 \mathrm{~mL}$ térfogatú folyadékmintára volt szükség, a hidrogéntermelés elemzéséhez használt $40 \mathrm{~mL}$-es üvegektől eltérően $120 \mathrm{~mL}$-es szérum üvegeket használtunk. Ezeket 105 mL folyadékkultúrával töltöttük fel, amely $15 \mathrm{~mL}$-es fennmaradó légteret eredményezett. Az ecetsav koncentráció csökkenésének detektálásához HPLC-t használtunk. A TAP tápoldatban a kiindulási ecetsav koncentráció $948 \mathrm{mg} \mathrm{L}^{-1}$ volt. Már az első nap után jelentős eltérést figyeltünk meg a tiszta Chlamydomonas sp. 549 és a kevert Chlamydomonas sp. $549-$ E. coli $\operatorname{hypF}\left(850 \mathrm{mg} \mathrm{L}^{-1}\right.$ vs. $476 \mathrm{mg} \mathrm{L}^{-1}$ ) kultúrák ecetsav felhasználásában. A második nap folyamán a tiszta Chlamydomonas sp. 549 kultúra ecetsav fogyasztása is felgyorsult, míg a kevert Chlamydomonas sp. 549 - E. coli $\Delta$ hypF kultúrában alig maradt ecetsav $\left(72 \mathrm{mg} \mathrm{L}^{-1}\right)$. A kevert alga-baktérium kultúrák esetében az ecetsav körülbelül $90 \%$-a $\left(948\right.$ mg L ${ }^{-1}$ vs. 72 mg $\mathrm{L}^{-1}$ ) már az első két nap folyamán felhasználódott, míg a tiszta algakultúra ezt a szintet a harmadik napon érte el $\left(948 \mathrm{mg} \mathrm{L}^{-1}\right.$ vs. $\left.123 \mathrm{mg} \mathrm{L}^{-1}\right)$. A kevert kultúra esetében a fogyás egyenletesnek mondható, míg a tiszta alga kultúrában az első nap csupán a teljes ecetsav mennyiség $10 \%$-a fogyott el $\left(948 \mathrm{mg} \mathrm{L}^{-1}\right.$ vs. $\left.850 \mathrm{mg} \mathrm{L}^{-1}\right)$. A kapott eredmények jól kiegészítik az alga biomassza növekedésének és hidrogéntermelésének adatait. Amint azt a későbbi alga és baktérium sejtszám változásokat tárgyaló fejezetekben majd bemutatjuk, az intenzívebb ecetsav- és energiafelhasználás gyorsabb alga sejtosztódást és eredményes alga hidrogéntermelést tett lehetővé a bakteriális partnert tartalmazó kultúrákban. 


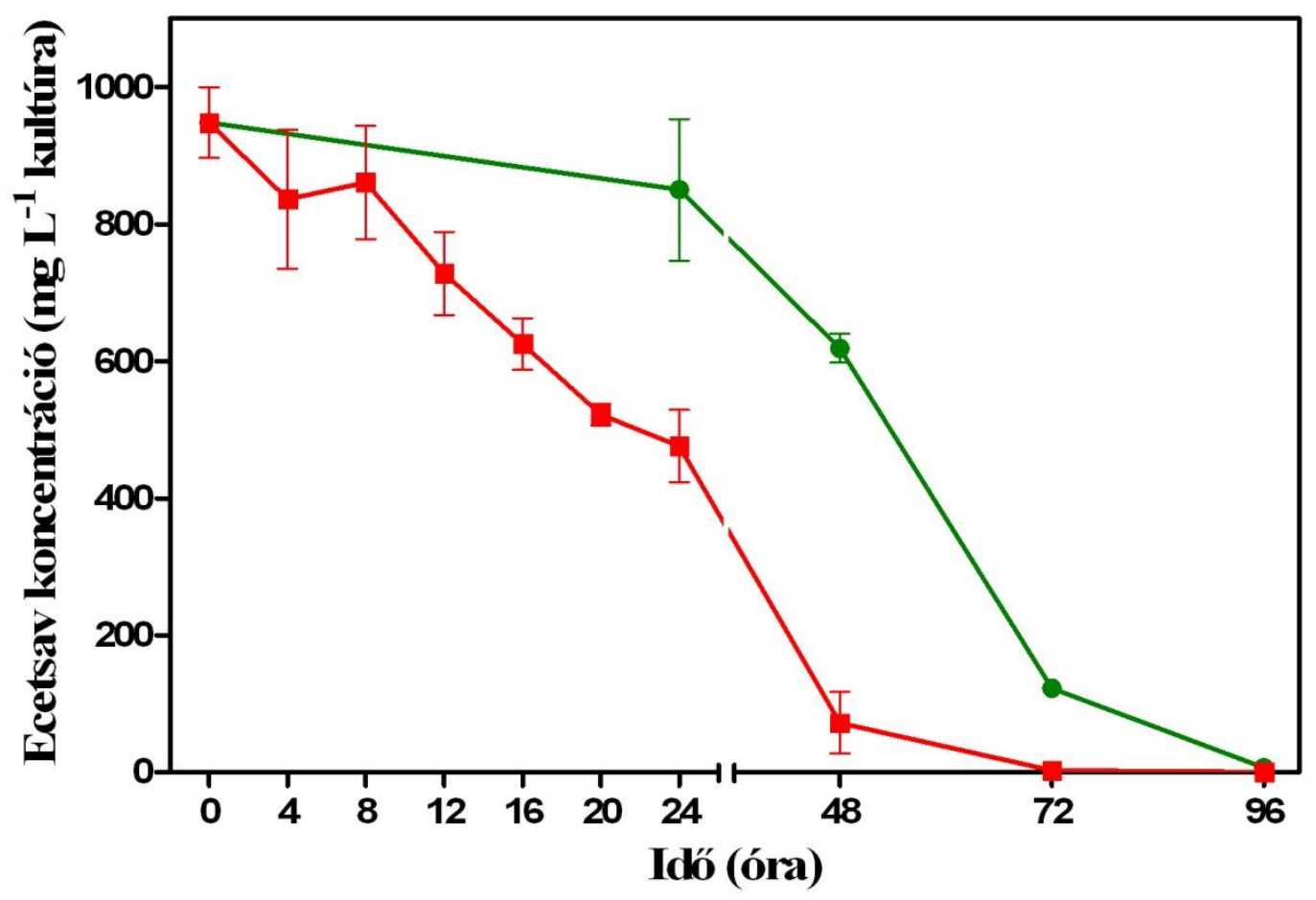

17. ábra: A tiszta Chlamydomonas sp. 549 (zöld zárt kör) és a kevert Chlamydomonas sp. 549 - E. coli $\triangle$ hypF (piros zárt négyzet) kultúrák ecetsav koncentráció csökkenésének összehasonlítása. A kísérlethez kultúránként három párhuzamos biológiai mintát használtunk és mindegyiken egy mérést végeztünk. A kapott adatokból átlagot és szórást számoltunk.

\subsubsection{Tiszta alga és baktérium, illetve kevert kultúrák pH változásai}

A fényen és sötétben inkubált tiszta Chlamydomonas sp. 549 és kevert Chlamydomonas sp. 549 - E. coli $\Delta$ hypF kultúrákat TAP tápoldatba oltottuk le, melynek pH értéke 7.3 volt. A tiszta Chlamydomonas sp. 549 és a kevert Chlamydomonas sp. 549 - E. coli $\Delta h y p F$ kultúrákban a $\mathrm{pH}$ szint négy napon keresztül fokozatosan emelkedett, majd $\mathrm{pH} 8.7$ körül stabilizálódott (18. ábra). A fényen inkubált tiszta E. coli $\Delta h y p F$ kultúrák, illetve a sötétben inkubált tiszta Chlamydomonas sp. 549, E. coli $\Delta$ hypF és a kevert Chlamydomonas sp. 549 - E. coli $\triangle$ hypF kultúrák pH szintje nem változott (18. ábra). 


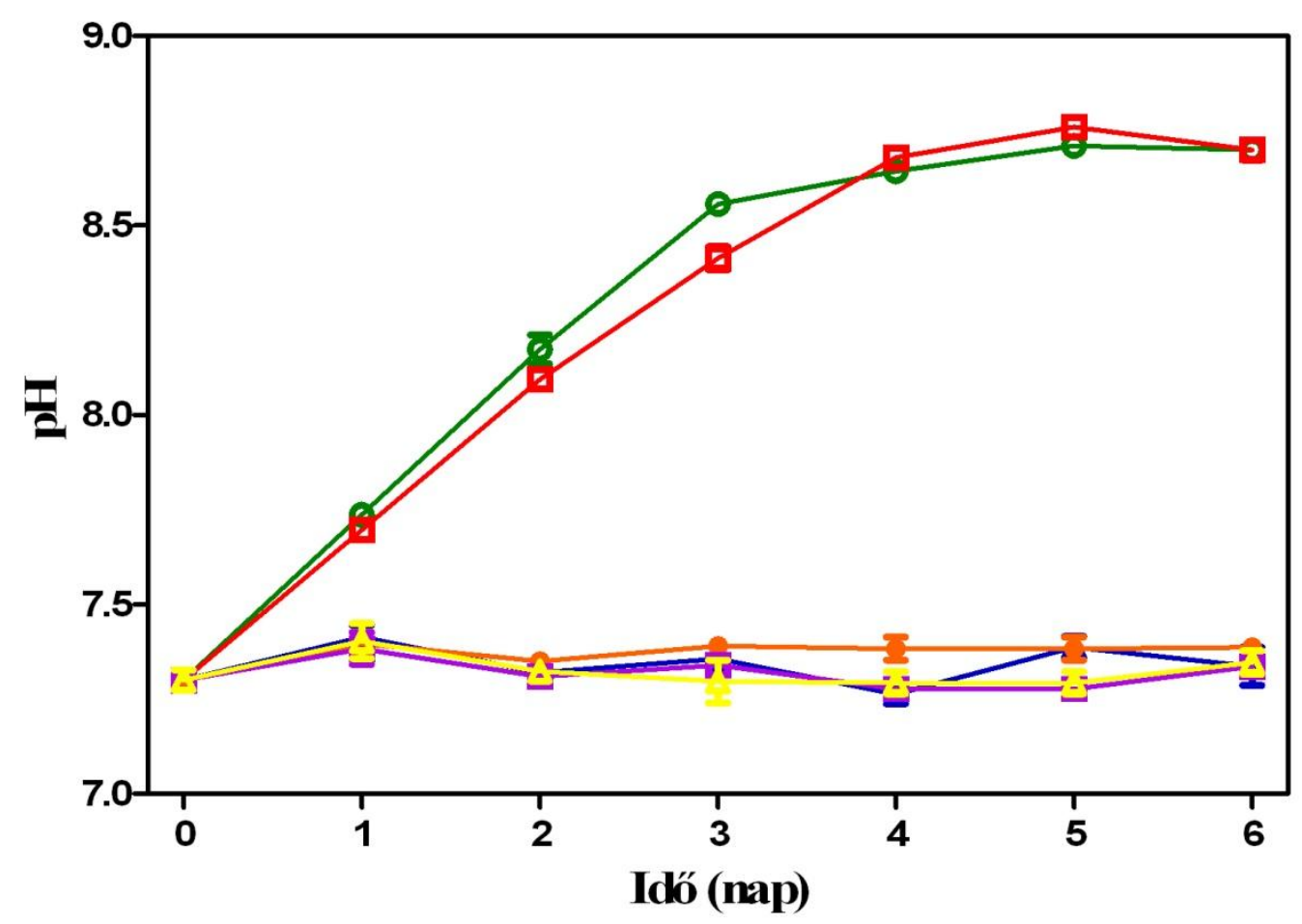

18. ábra: A fényen (nyitott jelek) és sötétben (zárt jelek) inkubált tiszta és vegyes kultúrák pH szintjeinek változásai. A fényen inkubált tiszta Chlamydomonas sp. 549 (zöld nyitott kör) és a kevert Chlamydomonas sp. 549-E. coli $\triangle$ hypF (piros nyitott négyzet) kultúrák pH szintje pH 7.3-ról pH 8.7-re emelkedett. A fényen inkubált tiszta E. coli $\Delta h y p F$ kultúra (sárga nyitott háromszög), illetve a sötétben inkubált tiszta Chlamydomonas sp. 549 (narancssárga zárt kör), E. coli $\triangle$ hypF (kék zárt háromszög) és a kevert Chlamydomonas sp. 549 - E. coli $\Delta$ hypF (lila zárt négyzet) kultúrák $\mathrm{pH}$ szintje nem változott. A kísérlethez kultúránként három párhuzamos biológiai mintát használtunk és mindegyiken három mérést végeztünk. A kapott adatokból átlagot és szórást számoltunk.

\subsection{Sejtszám változások vizsgálatai}

\subsubsection{Fényen és sötétben inkubált minták optikai denzitásának változásai}

A folyadékkultúrák elkészítéséhez az alga és baktérium törzseket először lemezen növesztettük, majd innen törzsoldatokba oltottuk át. Az így létrehozott alga és baktérium törzsoldatokból alkottuk meg a $35 \mathrm{~mL}$ végtérfogatú kultúráinkat, melyek optikai denzitása az alga esetében $750 \mathrm{~nm}$-en 0.7 , valamint a bakteriális partner esetében 600 nm-en 0.5 volt. A 
kultúrák optikai denzitásának változását ezután egységesen 750 nm-en mértük. Az optikai denzitás egyértelmủen azokban a mintákban növekedett, amelyek megvilágítást kaptak és alga partnert tartalmaztak. A sötétben inkubált tiszta Chlamydomonas sp. 549 és a kevert Chlamydomonas sp. 549 - Rhodococcus sp., valamint a fényen és sötétben inkubált Rhodococcus sp. optikai denzitása lassú csökkenést mutatott a mérések során (19. ábra).

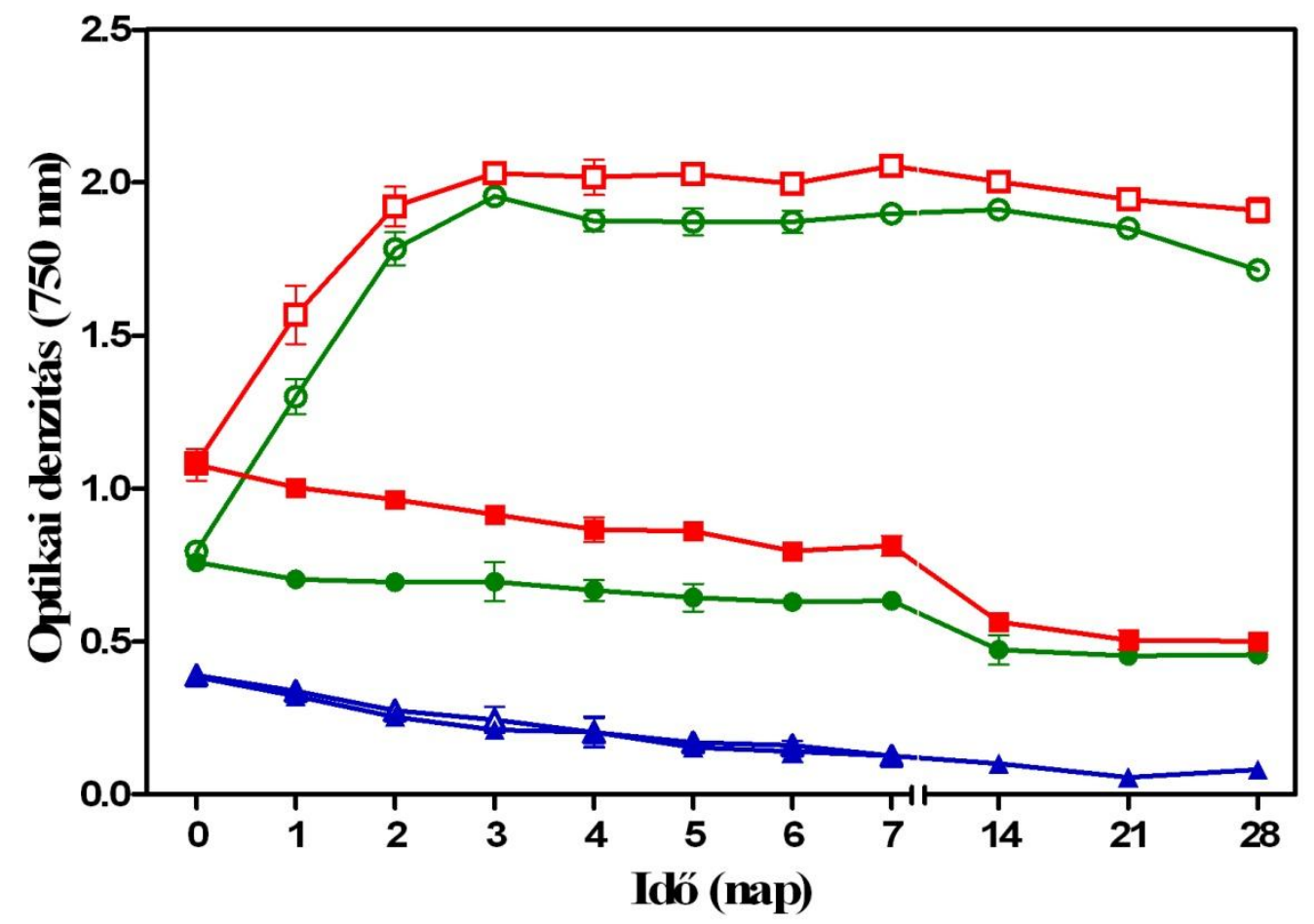

19. ábra: A fényen (nyitott jelek) és sötétben (zárt jelek) inkubált tiszta Chlamydomonas sp. 549 (zöld kör) és Rhodococcus sp. (kék háromszög), valamint a kevert Chlamydomonas sp. 549 - Rhodococcus sp. (piros négyzet) kultúrák optikai denzitásának változásai. A kísérlethez kultúránként három párhuzamos biológiai mintát használtunk és mindegyiken három mérést végeztünk. A kapott adatokból átlagot és szórást számoltunk.

\subsubsection{Alga sejtszám változás fényen és sötétben, TAP és TP tápban}

Az alga sejtszámlálást Bürker-kamrával mikroszkóp alatt végeztük. $10 \mu \mathrm{L}$ mintát vittünk fel a tárgylemezre. Fényen, a TAP tápoldatban növesztett Chlamydomonas sp. 549 sejtszáma négy napon keresztül növekedett az axénikus és a Rhodococcus sp.-vel kevert kultúrákban egyaránt. A két kultúra alga sejtszámának növekedésében eltérést elsősorban az 
első nap során figyeltünk meg. A Chlamydomonas sp. 549 - Rhodococcus sp. kevert kultúrában az első nap gyorsabban növekedett az alga sejtszáma, mint a tiszta Chlamydomonas sp. 549 kultúrában. Ez a sejtszámbeli különbség a kísérlet során végig megmaradt (20. ábra). Sötétben, a TAP tápoldatban nevelt kultúrákban a vártnak megfelelően nem láttunk sejtszámbeli változást, sem pozitív sem negatív irányban. A TP tápoldatba leoltott kevert Chlamydomonas sp. 549 - Rhodococcus sp. kultúrák az ecetsav hiányában nem nőttek sem megvilágítás mellett sem pedig sötétben. Összességében a sötétben és a TP tápban inkubált minták sejtszámai a négyhetes méréssorozat során a kiindulási érték körül mozogtak.

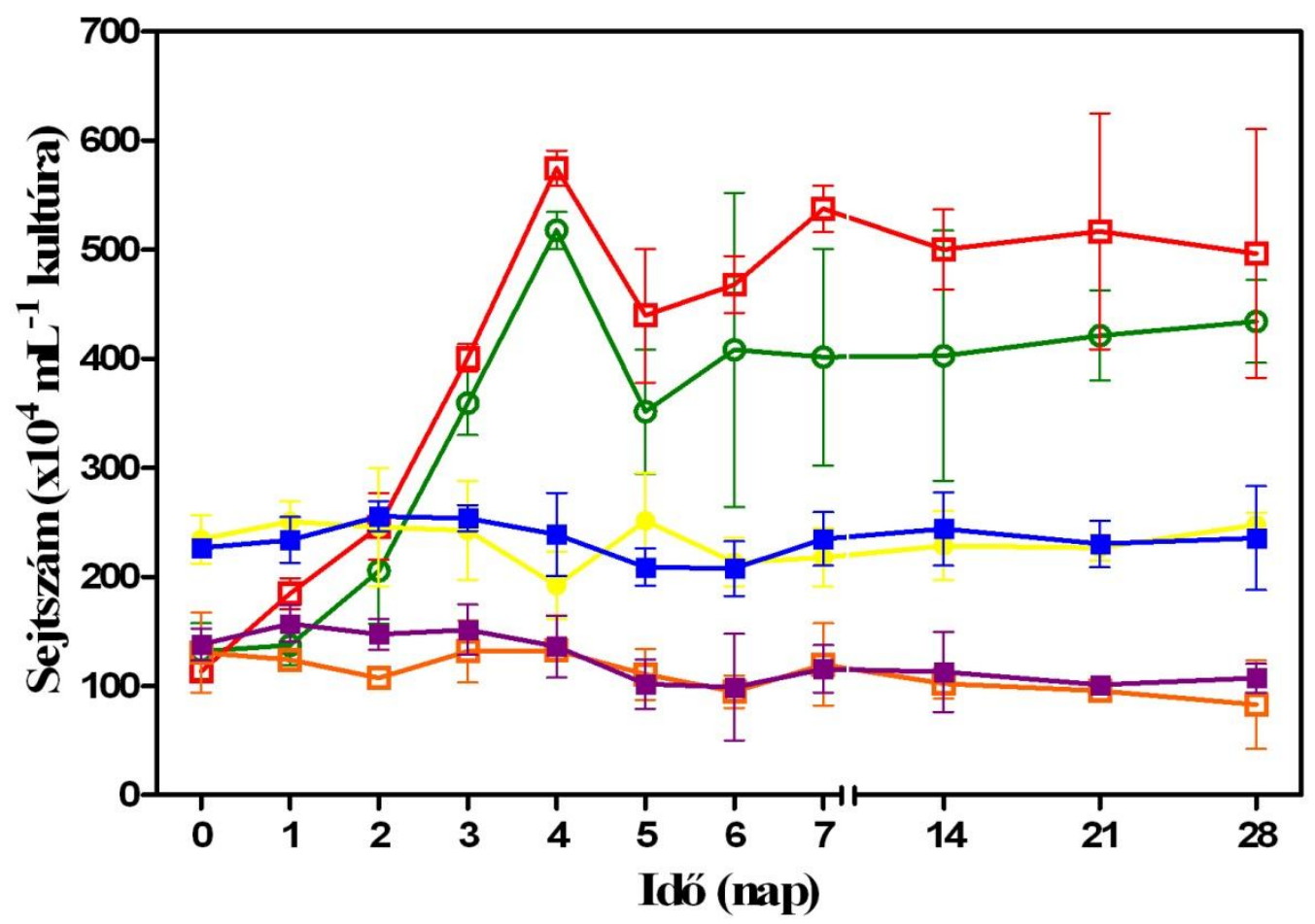

20. ábra: Alga sejtszám változás fényen, TAP tápoldatban inkubált Chlamydomonas sp. 549 (zöld nyitott kör) és Chlamydomonas sp. 549 - Rhodococcus sp. (piros nyitott négyzet) kultúrákban; sötétben, TAP tápoldatban inkubált Chlamydomonas sp. 549 (sárga zárt kör) és Chlamydomonas sp. 549 - Rhodococcus sp. (kék zárt négyzet) kultúrákban; fényen TP tápoldatban inkubált Chlamydomonas sp. 549 - Rhodococcus sp. (narancssárga nyitott négyzet) és sötétben TP tápoldatban inkubált Chlamydomonas sp. 549 - Rhodococcus sp. (lila zárt négyzet) kultúrákban. A kísérlethez kultúránként három párhuzamos biológiai mintát használtunk és mindegyiken három sejtszámlálást végeztünk. A kapott adatokból átlagot és szórást számoltunk. 


\subsubsection{Bakteriális sejtszám változás fényen és sötétben}

A Rhodococcus sp. élő sejtszámát LB lemezeken számoltuk meg többlépéses hígítási sort alkalmazva. A TAP tápoldatban, fényen inkubált Chlamydomonas sp. 549 - Rhodococcus sp. vegyes kultúrában a bakteriális sejtszám egy napig állandó maradt, majd a második napra jelentősen redukálódott. Ezt követően a negyedik napig stabil maradt, majd az ötödik napra ismét jelentősen csökkent a sejtszám. A fényen és sötétben tartott tiszta Rhodococcus sp. és a sötétben inkubált kevert Chlamydomonas sp. 549 - Rhodococcus sp. kultúrákban a bakteriális sejtszám az első két nap során jelentős redukción ment keresztül, majd a kísérlet végéig alacsony szinten maradt.

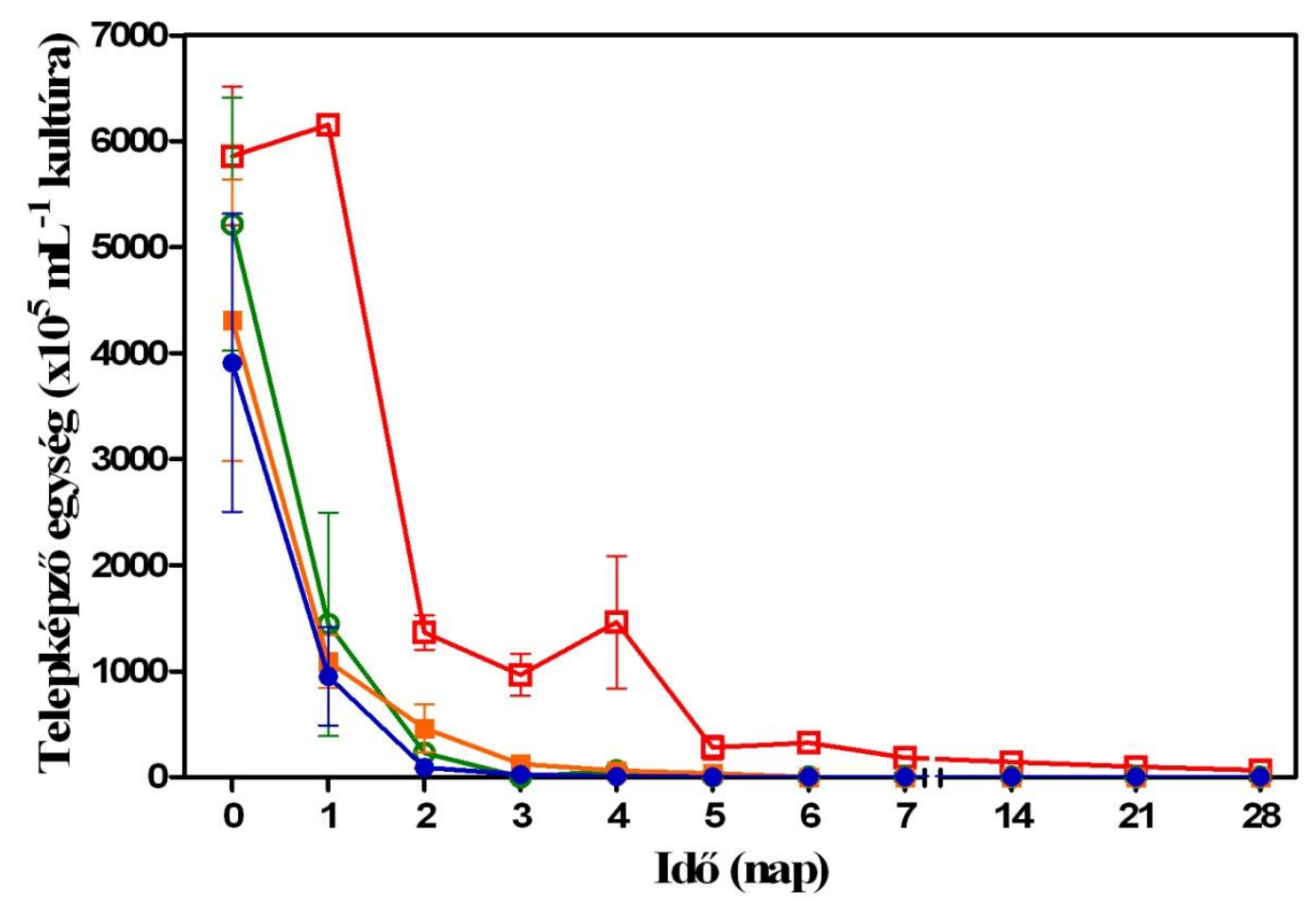

21. ábra: Rhodococcus sp. sejtszám változása fényen inkubált Rhodococcus sp. (zöld nyitott kör) és Chlamydomonas sp. 549 - Rhodococcus sp. (piros nyitott négyzet) kultúrákban, valamint sötétben inkubált Rhodococcus sp. (kék zárt kör) és Chlamydomonas sp. 549 Rhodococcus sp. (narancssárga zárt négyzet) kultúrákban. A kísérlethez kultúránként három párhuzamos biológiai mintát használtunk és mindegyiken három sejtszámolást végeztünk. $\mathrm{A}$ kapott adatokból átlagot és szórást számoltunk. 


\subsection{Az alga-baktérium konzorciális hidrogéntermelés kombinálása fermentatív és kénmegvonáson alapuló hidrogéntermelő megközelítésekkel}

\subsubsection{Fermentatív hidrogéntermelés sötétben}

A biológiai úton végbemenő biohidrogén előállítás sötét fermentáció útján is történhet. Ezt a technológiát leginkább baktériumoknál alkalmazzák, de számos kísérleti eredmény is igazolja, hogy zöldalgák esetében is müködik. Az eddigi pozitív eredményeink alapján felmerült az ötlet az általunk vizsgált módszer és a már ismert sötét fermentációs hidrogéntermelő módszer kombinálására. A két technika együttes használatának vizsgálatához a tiszta Chlamydomonas sp. 549 alga kultúrát, a tiszta E. coli $\Delta$ hypF baktérium kultúrát, valamint ezek alga-baktérium keverék kultúráit használtuk. A tiszta alga és a kevert algabaktérium kultúra esetében a hidrogén felhalmozódása a légtérben négy napig tartott, szemben a korábban megfigyelt 12-24 órás rövid periódusnál (7., 12., 14. ábra). A két kultúra által termelt hidrogén mennyisége nagyságrendileg megegyezett, jelentős különbséget nem tudtunk kimutatni a tiszta alga $\left(6114 \pm 369 \mu \mathrm{L} \mathrm{L}^{-1}\right)$ és az alga-baktérium keverék $(5621 \pm 645$ $\mu \mathrm{L} \mathrm{L}^{-1}$ ) sötét fermentációs eredményei között (22. ábra). A vegyes kultúrák által fényen $\left(1196.06 \pm 4.42 \mu \mathrm{L} \mathrm{L}^{-1}\right)$ (14. ábra) és sötétben $\left(5621 \pm 645 \mu \mathrm{L} \mathrm{L}^{-1}\right)$ (22. ábra), az összes megtermelt hidrogént tekintve megközelítőleg ötszörös mennyiségi különbséget figyeltünk meg. A korábbi kísérletekhez hasonlóan a tiszta baktérium kultúra sötét körülmények között sem termelt hidrogént. 


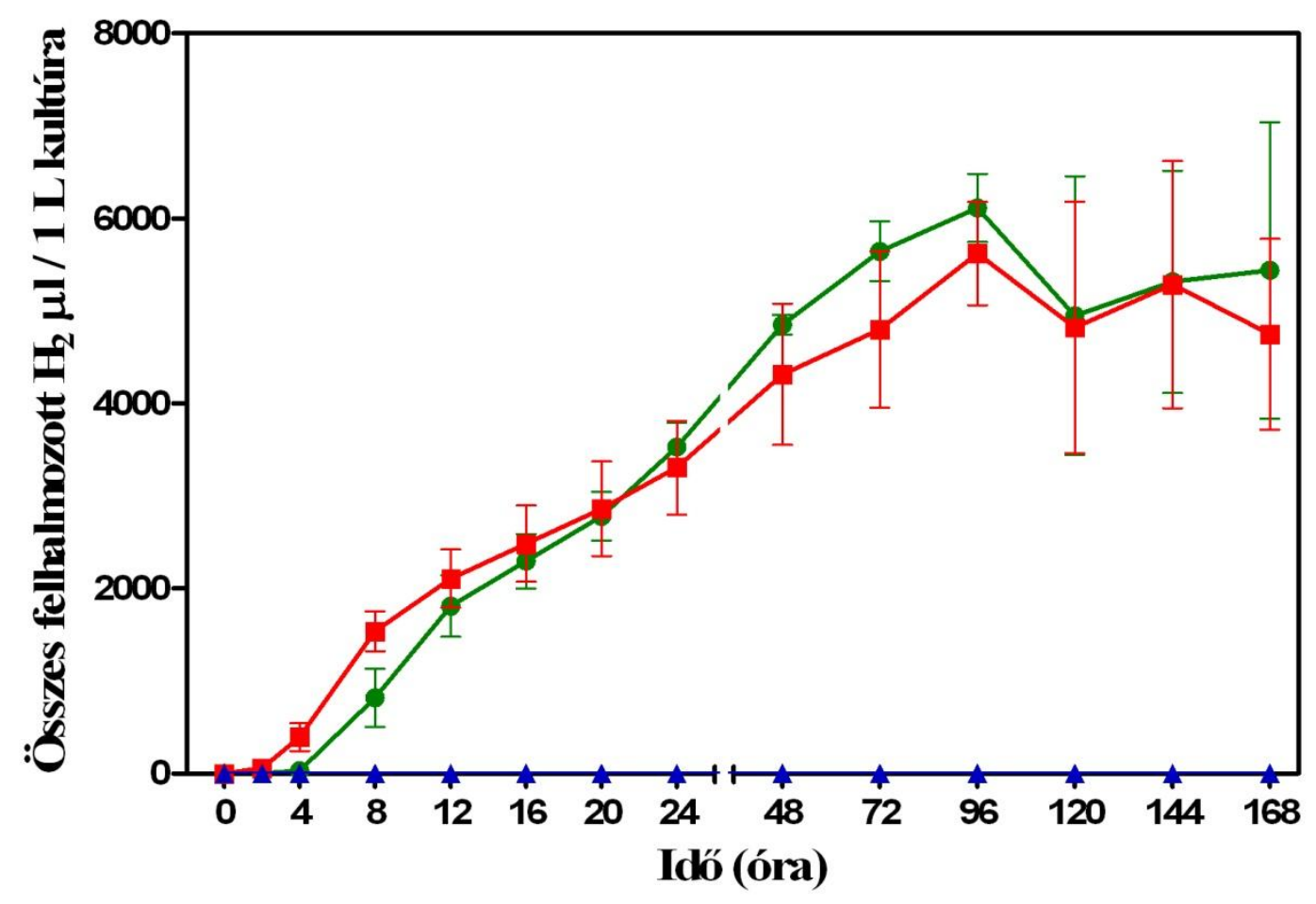

22. ábra: Fermentatív hidrogéntermelés sötétben. A tiszta Chlamydomonas sp. 549 (zöld zárt kör) és a vegyes Chlamydomonas sp. 549 - E. coli $\Delta$ hypF (piros zárt négyzet) kultúrák hasonló mennyiségü hidrogént termeltek, míg a tiszta E. coli $\Delta$ hypF (kék zárt háromszög) kultúra nem termelt hidrogént. A kísérlethez kultúránként három párhuzamos biológiai mintát használtunk és mindegyiken három mérést végeztünk. A kapott adatokból átlagot és szórást számoltunk.

A sötét fermentáció során mindegyik kultúra légterének oxigén szintje gyorsan csökkent 4\%-ra és a kísérlet végéig stabilan ezen a szinten is maradt. Az E. coli $\Delta$ hypF-et tartalmazó kultúrák 4 óra alatt, míg a tiszta Chlamydomonas sp. 549 kultúra 8 óra alatt redukálta 4\%-ra a légtér oxigén szintjét (23. ábra). Az értékek közötti különbség feltételezésünk szerint a bakteriális partner aktív légzésének tulajdonítható. 


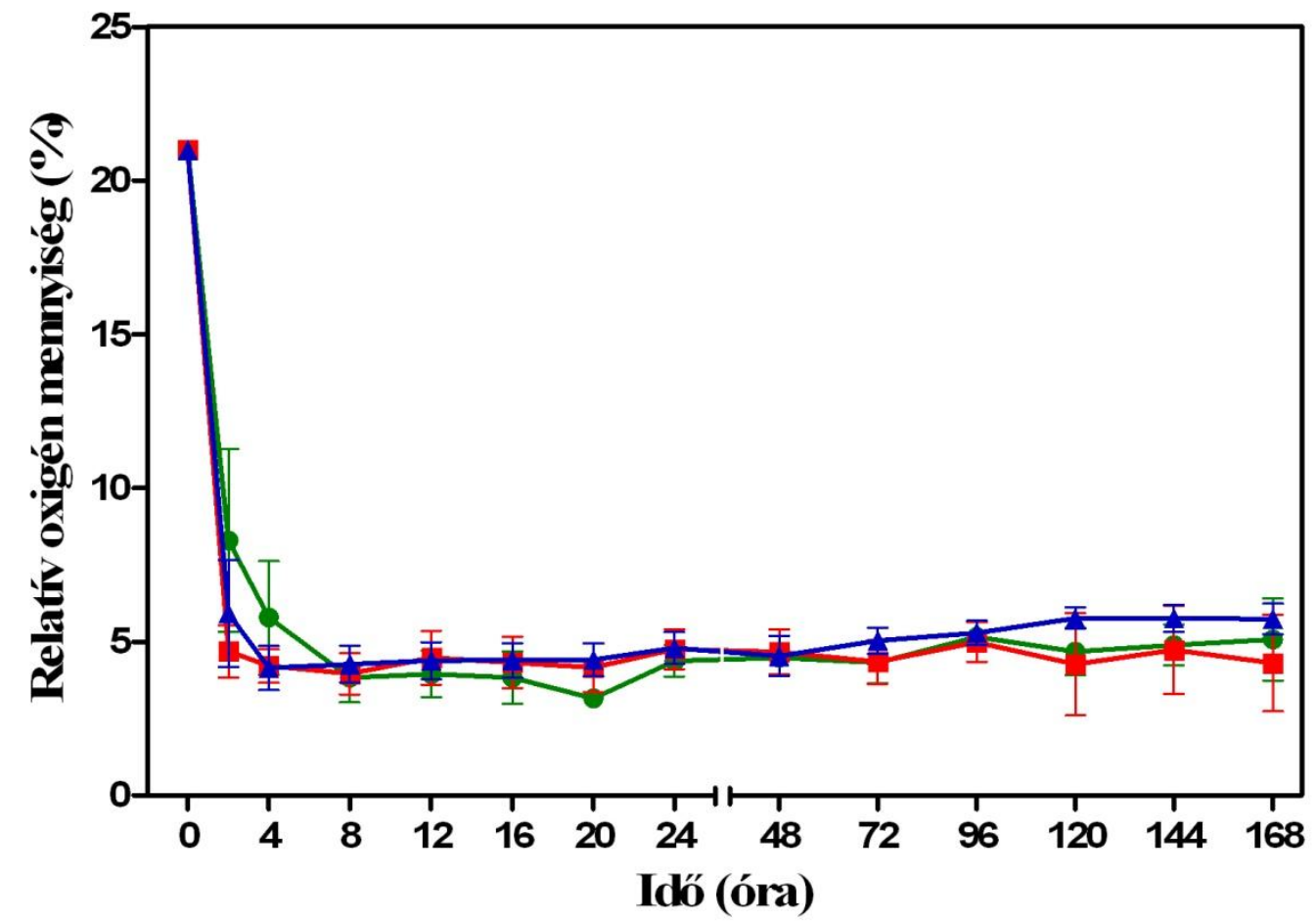

23. ábra: Oxigénszint értékek változása a sötét fermentáció során a tiszta Chlamydomonas sp. 549 (zöld zárt kör), a tiszta E. coli $\Delta$ hypF (kék zárt háromszög) és a vegyes Chlamydomonas sp. 549 - E. coli $\triangle$ hypF (piros zárt négyzet) kultúrák légterében. A kísérlethez kultúránként három párhuzamos biológiai mintát használtunk és mindegyiken három mérést végeztünk. $\mathrm{A}$ kapott adatokból átlagot és szórást számoltunk.

\subsubsection{Hidrogéntermelés kénmegvonás útján tiszta és bakteriális partnert tartalmazó Chlamydomonas kultúrákkal}

A Chlamydomonas törzsekkel kénmegvonás útján végbemenő hidrogéntermelésnek másfél évtizedre visszatekintő, komoly kutatási háttere van. A kénmegvonás útján történő biohidrogéntermelés vizsgálatához az eddig használt Chlamydomonas sp. 549 törzs mellett viszonyítási alapként a már korábbi fényen történő hidrogéntermeléssel foglalkozó cikkekben részletesen leírt $C h$. reinhardtii cc124 törzset használtuk. Mivel kénmentes tápoldatban a tápanyaghiány miatt az alga növekedése gátolt, ezért mind a Chlamydomonas sp. 549, mind pedig a Ch. reinhardtii cc124 törzseket ként tartalmazó Tris-foszfát lemezeken növesztettük. Az így kapott biomasszát viszont kénmentes tápoldatba oltottuk át. Bakteriális partnerként a már eddigi kísérleteink során is használt $E$. coli hidrogenáz deficiens változatát alkalmaztuk. 
A kísérlet során a Chlamydomonas sp. 549, a Ch. reinhardtii cc124 és ezek E. coli $\Delta h y p F$-fel kevert kultúráinak hidrogéntermelését hasonlítottuk össze. A hidrogéntermelés dinamikájának és termelt mennyiségének szempontjából a két algatörzs tiszta és kevert kultúrája jelentős eltérést mutatott. Fényen kénmegvonás mellett a tiszta Chlamydomonas sp. 549 kultúra kis mennyiségü $\left(193.5 \pm 66.81 \mu \mathrm{L} \mathrm{L}^{-1}\right)$, míg a tiszta $C h$. reinhardtii cc124 kultúra (25028.1 $\left.\pm 3943.47 \mu \mathrm{L} \mathrm{L}^{-1}\right)$ két nagyságrenddel több hidrogént termelt. Hasonló különbséget figyeltünk meg a kevert kultúrák által termelt hidrogén mennyiségek között is. A fényen kénmegvonás mellett inkubált $C h$. reinhardtii cc124 - E. coli $\Delta$ hypF $(47241.3 \pm 4660.69 \mu \mathrm{L}$ $\mathrm{L}^{-1}$ ) megközelítőleg egy nagyságrenddel több hidrogént termelt, mint a Chlamydomonas sp. 549 - E. coli $\Delta$ hypF $\left(2637.49 \pm 555.42 \mu \mathrm{L} \mathrm{L}^{-1}\right)$ kevert kultúra.

A tiszta és kevert kultúrák között is szignifikáns a különbség az összes felhalmozott hidrogén mennyiség tekintetében. A Chlamydomonas sp. 549 törzs tiszta és kevert kultúráját nézve körülbelül egy nagyságrendnyi mennyiségi különbséget fedeztünk fel (193.5 \pm 66.81 $\mu \mathrm{L} \mathrm{L}^{-1}$ illetve $2637.49 \pm 555.42 \mu \mathrm{L} \mathrm{L}^{-1}$ ), míg a Ch. reinhardtii cc124 esetében ez kétszeres mennyiséget jelentett a kevert kultúrában a tiszta kultúrához képest $(25028.1 \pm 3943.47 \mu \mathrm{L}$ $\mathrm{L}^{-1}$ illetve $\left.47241.3 \pm 4660.69 \mu \mathrm{L} \mathrm{L}^{-1}\right)$.

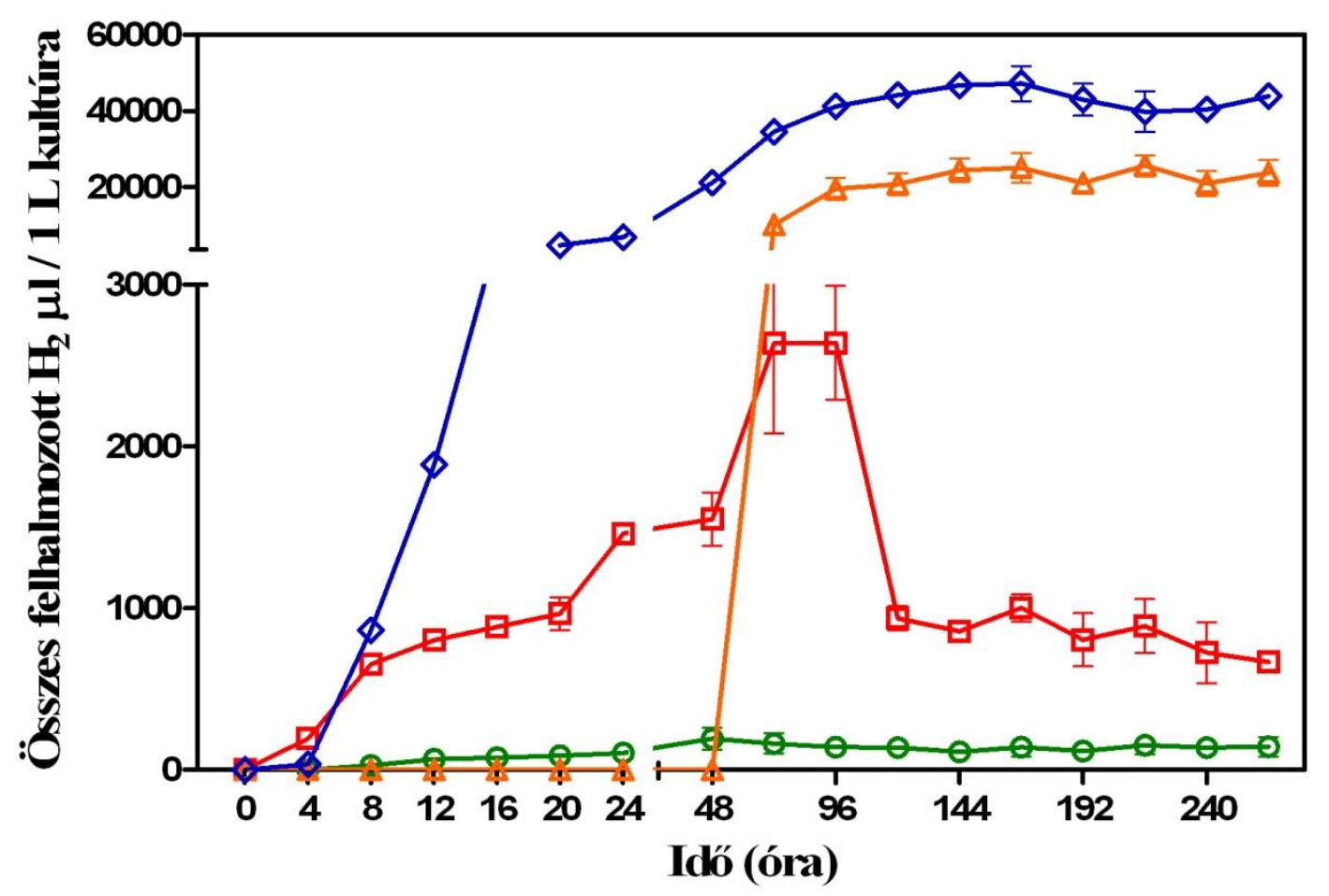

24. ábra: Hidrogéntermelés kénmegvonás mellett tiszta és bakteriális partnert tartalmazó Chlamydomonas kultúrákkal. A TAP-S tápoldatba oltott Chlamydomonas sp. 549 (zöld 
nyitott kör), Chlamydomonas sp. 549 - E. coli $\Delta$ hypF (piros nyitott négyzet), Ch. reinhardtii cc124 (narancssárga nyitott háromszög) és Ch. reinhardtii cc124 - E. coli $\Delta$ hypF (kék nyitott rombusz) kultúrák hidrogéntermelését vizsgáltuk fényen. A kísérlethez kultúránként három párhuzamos biológiai mintát használtunk és mindegyiken három mérést végeztünk. A kapott adatokból átlagot és szórást számoltunk.

A különböző kultúrák légterének oxigénszint értékei egymáshoz viszonyítva, a hidrogén mennyiségekhez hasonlóan, jelentős eltéréseket mutattak. A kénmentes tápban fényen inkubált tiszta alga kultúrák oxigén szintje az első nap során a kiindulási $21 \%$-ról 15 $17 \%$-ra redukálódott. 24 óra eltelte után a Chlamydomonas sp. 549 kultúra légterének oxigénszintje két nap alatt $50 \%$-ra emelkedett, míg a $C h$. reinhardtii cc124 kultúra légterében az oxigén szint három nap alatt $2 \%$-ra redukálódott. Az E. coli $\Delta$ hypF bakteriális partnert tartalmazó kultúrák légterében az oxigénszint négy óra alatt $5 \%$ alá csökkent. A $C h$. reinhardtii cc124-et tartalmazó kultúrák légterének oxigénszintje a kísérlet végéig $2 \%$ körül maradt. A Chlamydomonas sp. 549 - E. coli $\triangle$ hypF kultúra légterének relatív oxigén szintje a negyedik nap után két nap alatt $2 \%$-ról $22 \%$-ra nőtt, majd a hatodik nap után három nap alatt ismét $5 \%$ alá csökkent.

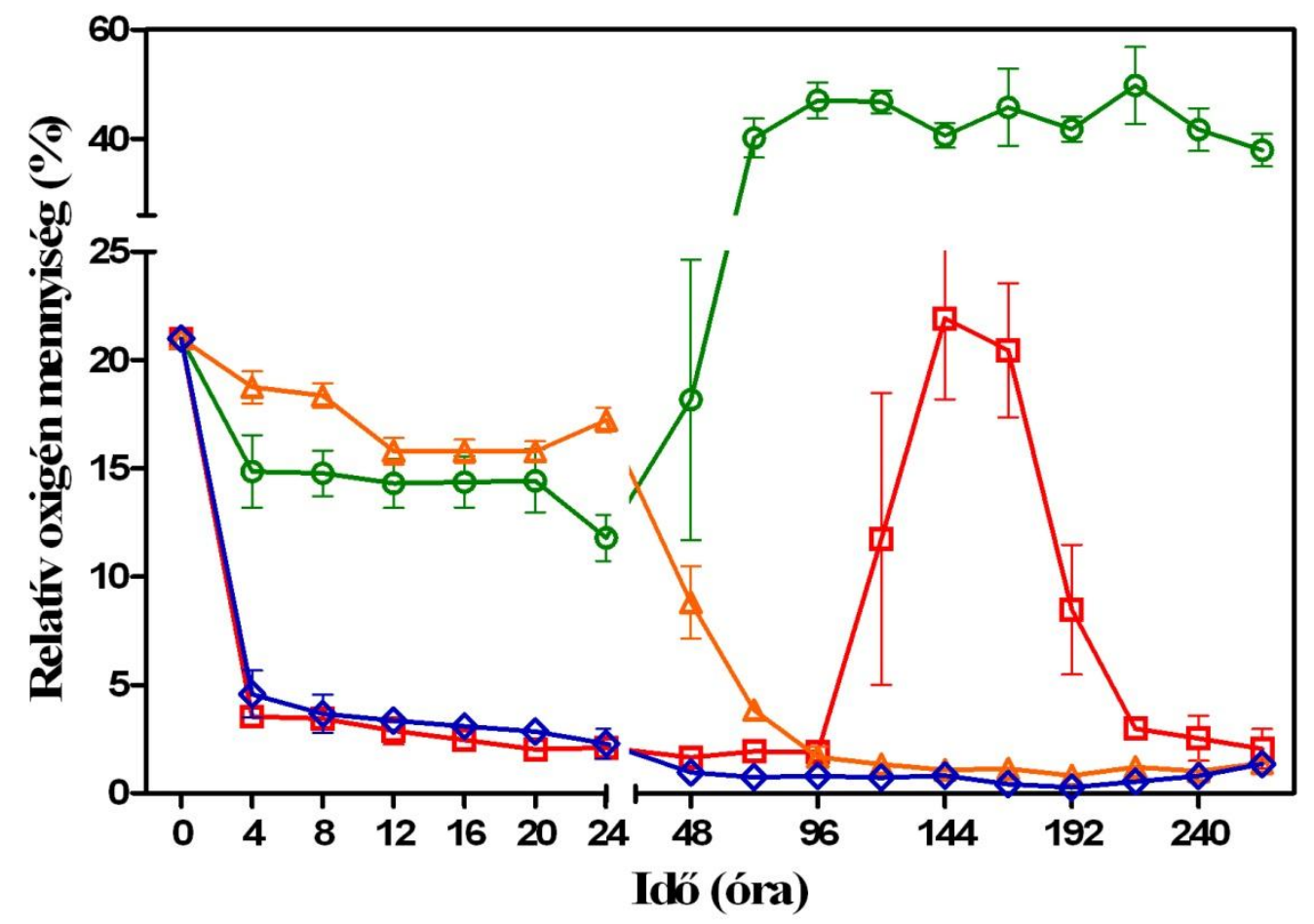


25. ábra: Relatív oxigénszint változások a kénmentes TAP tápban inkubált kultúrák légterében. A TAP-S tápoldatba oltott Chlamydomonas sp. 549 (zöld nyitott kör), Chlamydomonas sp. 549 - E. coli $\triangle$ hypF (piros nyitott négyzet), Ch. reinhardtii cc124 (narancssárga nyitott háromszög) és Ch. reinhardtii cc124 - E. coli $\Delta$ hypF (kék nyitott rombusz) kultúrák légterének oxigénszint változását vizsgáltuk fényen. A kísérlethez kultúránként három párhuzamos biológiai mintát használtunk és mindegyiken három mérést végeztünk. A kapott adatokból átlagot és szórást számoltunk.

\subsection{A fotoszintetikus rendszer vizsgálata a hidrogéntermelés során}

\subsubsection{PSII müködésének vizsgálata klorofill fluoreszcenciás mérésekkel}

A hidrogéntermelés kén-megvonásos módszerének kulcsmotívuma a PSII müködésének a leállítása. Az általunk vizsgált Chlamydomonas sp. 549 esetében felmerült a kérdés, hogy miért kaptunk ennyire eltérő értékeket a $C h$. reinhardtii cc124 eredményeihez képest mind a hidrogéntermelés, mind pedig a relatív oxigénszint terén. A PSII maximális kvantumhatásfok mérései rávilágítottak arra a tényre, hogy a Chlamydomonas sp. 549-ben a PSII lassabban degradálódott (26. ábra), mint a Ch. reinhardtii cc124-ben (Scoma és mtsai. 2012). Ahogy a 25. ábrán az oxigénszintekből és 26. ábrán a $F_{V} / F_{M}$ fluoreszcencia paraméterből látszik, a Chlamydomonas sp. 549-ben a PSII aktivitása körülbelül egy hét után csökkent olyan szintre, hogy az alga sejtlégzése több oxigént fogyasztott, mint amennyit a fotoszintézise során termelt . Míg a Ch. reinhardtii cc124 esetében az oxigén szint az első nap után folyamatos csökkenést mutatott (25. ábra) a PSII aktivitásának folyamatos csökkenése mellett (Scoma és mtsai. 2012). 


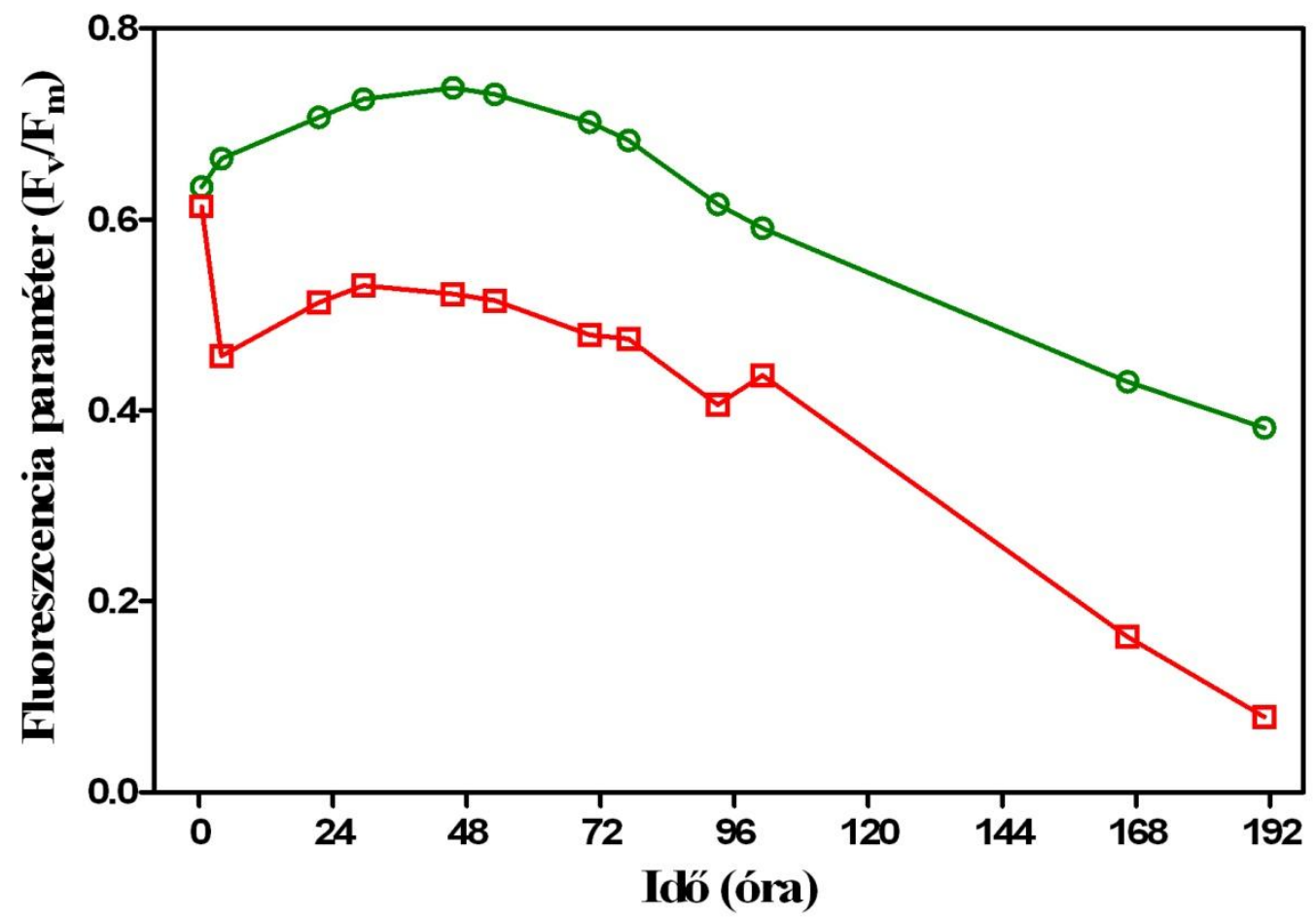

26. ábra: A tiszta Chlamydomonas sp. 549 (zöld nyitott kör) és a kevert Chlamydomonas sp. 549 - E. coli $\triangle h y p F$ (piros nyitott négyzet) kultúrák $\mathrm{F}_{\mathrm{V}} / \mathrm{F}_{\mathrm{M}}$ fluoreszcencia paraméterváltozása. A kísérlethez kultúránként egy párhuzamos biológiai mintát használtunk és mindegyiken egy mérést végeztünk.

\subsubsection{Az alga fotoszintetikus aktivitásának vizsgálata}

A kísérletek során nyomon követtük az alga fotoszintetikus rendszerének a változását. Klorofill fluoreszcencia mérésekkel határoztuk meg az alga-baktérium kultúrák PSII aktivitását. Az alga-baktérium kultúra 24 órával a kísérlet kezdete után mért OJIP tranziensének a J-értéke a kontroll, baktériummentes alga kultúrához viszonyítva jelentős emelkedést mutatott (27. ábra, A panel). Ez azt mutatja, hogy a PQ-pool jelentősen redukálódott az adott körülmények során. Miután 10 percig levegővel buborékoltattuk át a mintát, annak J-értéke visszaállt, és az OJIP tranziens a kontrollhoz nagyon hasonlóvá vált. $\mathrm{Az}$ átbuborékoltatott kevert és baktériummentes kultúrákban mért $F_{\mathrm{v}} / F_{\mathrm{m}}$ értékek nagy hasonlóságot mutattak (0.62 és 0.66), vagyis a PSII maximális kvantumhatásfoka a baktérium jelenlétének hatására nem változott meg jelentősen. 
A fényimpulzus-indukált fluoreszcencia hatásfok lecsengés kinetikája a $\mathrm{Q}_{\mathrm{A}}{ }^{-}$ oxidálódását tükrözi, mely jelenség jól magyarázható a széles körben elfogadott két-elektron kapu modell alapján (Vass és mtsai. 1999). A gyors fázis (néhány száz mikroszekundum) a $\mathrm{Q}_{\mathrm{A}}{ }^{-}$oxidálódását mutatja az előremenő elektrontranszport által azokban a PSII centrumokban, amelyek tartalmaztak kötött PQ molekulát a gerjesztés előtt. A középső fázis (néhány milliszekundum) azokat a centrumokat tükrözi, melyekben a gerjesztés pillanatában a $\mathrm{Q}_{\mathrm{B}}$ kötőhely üres, a PQ-pool-ból egy PQ molekulának be kell kötődnie mielőtt a $Q_{A}$-ról az elektron a $\mathrm{Q}_{\mathrm{B}}$-re jut. A lassú fázisban (néhány másodperc) a reoxidáció az akceptor oldali negatív töltés $\left(\mathrm{Q}_{\mathrm{A}}{ }^{-}\right)$és a vízbontó komplex pozitív töltéssel rendelkező $\mathrm{S}_{2}$ állapota közötti töltésrekombináció eredménye. Az alga fényimpulzus-indukált fluoreszcencia hatásfok lecsengése a 24 órás inkubáció után jelentősen lassabb volt a kevert kultúrákban a kontrollokhoz viszonyítva (27. ábra, B panel). A baktérium jelenlétében anaerob körülmények között a gyors fázis amplitúdója teljesen eltűnt, míg a lassú fázisé növekedett. Mindebből arra a következtetésre jutottunk, hogy sötétben, oxigén hiányában a $\mathrm{Q}_{\mathrm{B}}$ kötőhelyek nem tartalmaznak olyan oxidált vagy egyszeresen redukált plasztokinon molekulákat, amelyek képesek a $\mathrm{Q}_{\mathrm{A}}{ }^{-}$-ról elektronokat fogadni. A PSI által a cytb $/$/f-en keresztül történő $\mathrm{PQH}_{2}$ oxidálása után a plasztokinon molekulák a közép fázisban képesek a $Q_{B}$ kötőhelyhez kötődni és a $\mathrm{Q}_{\mathrm{A}}^{-}{ }^{-\mathrm{t}}$ újra oxidálni. Mindez anaerob körülmények mellett egy lassabb lineáris elektrontranszportot eredményez a PSII és a PSI között. A kultúrák tíz percen keresztül tartó buborékoltatásával az elektrontranszport ilyen típusú lassulása teljes mértékben visszafordítható volt.

\begin{tabular}{|l|c|c|c|l|}
\hline & \multicolumn{1}{|c|}{$\begin{array}{c}\text { Gyors fázis } \\
\mathrm{T}_{1}(\mu \mathrm{s}) / \mathrm{A}_{1}(\%)\end{array}$} & $\begin{array}{c}\text { Közép fázis } \\
\mathrm{T}_{2}(\mathrm{~ms}) / \mathrm{A}_{2}(\%)\end{array}$ & $\begin{array}{c}\text { Lassú fázis } \\
\mathrm{T}_{3}(\mathrm{~s}) / \mathrm{A}_{3}(\%)\end{array}$ & \multicolumn{1}{c|}{$\mathrm{A}_{0}(\%)$} \\
\hline Tiszta & $585 \pm 98 / 38.9 \pm 2.8$ & $5.0 \pm 0.7 / 34.6 \pm 3.1$ & $3.5 \pm 0.5 / 26.5 \pm 0.7$ & 0 \\
Kevert & $-/ 0$ & $8.9 \pm 0.7 / 33.6 \pm 0.8$ & $3.1 \pm 0.2 / 61.4 \pm 0.8$ & $5.0 \pm 0.8$ \\
$\begin{array}{l}\text { Kevert, 10 } \\
\text { perc levegő }\end{array}$ & $511 \pm 92 / 35.2 \pm 2.4$ & $5.4 \pm 0.6 / 34.8 \pm 2.5$ & $2.9 \pm 0.3 / 30.0 \pm 0.7$ & 0 \\
\hline
\end{tabular}

3. táblázat: A fényimpulzus-indukált fluoreszcencia lecsengési kinetikák alga-baktérium kevert és tiszta alga kultúrákban 24 órás inkubáció után. A kinetikákat két exponenciális (gyors és középső fázis), egy hiperbolikus (lassú fázis), és egy nem lecsengő komponenst tartalmazó függvénnyel illesztettük. 

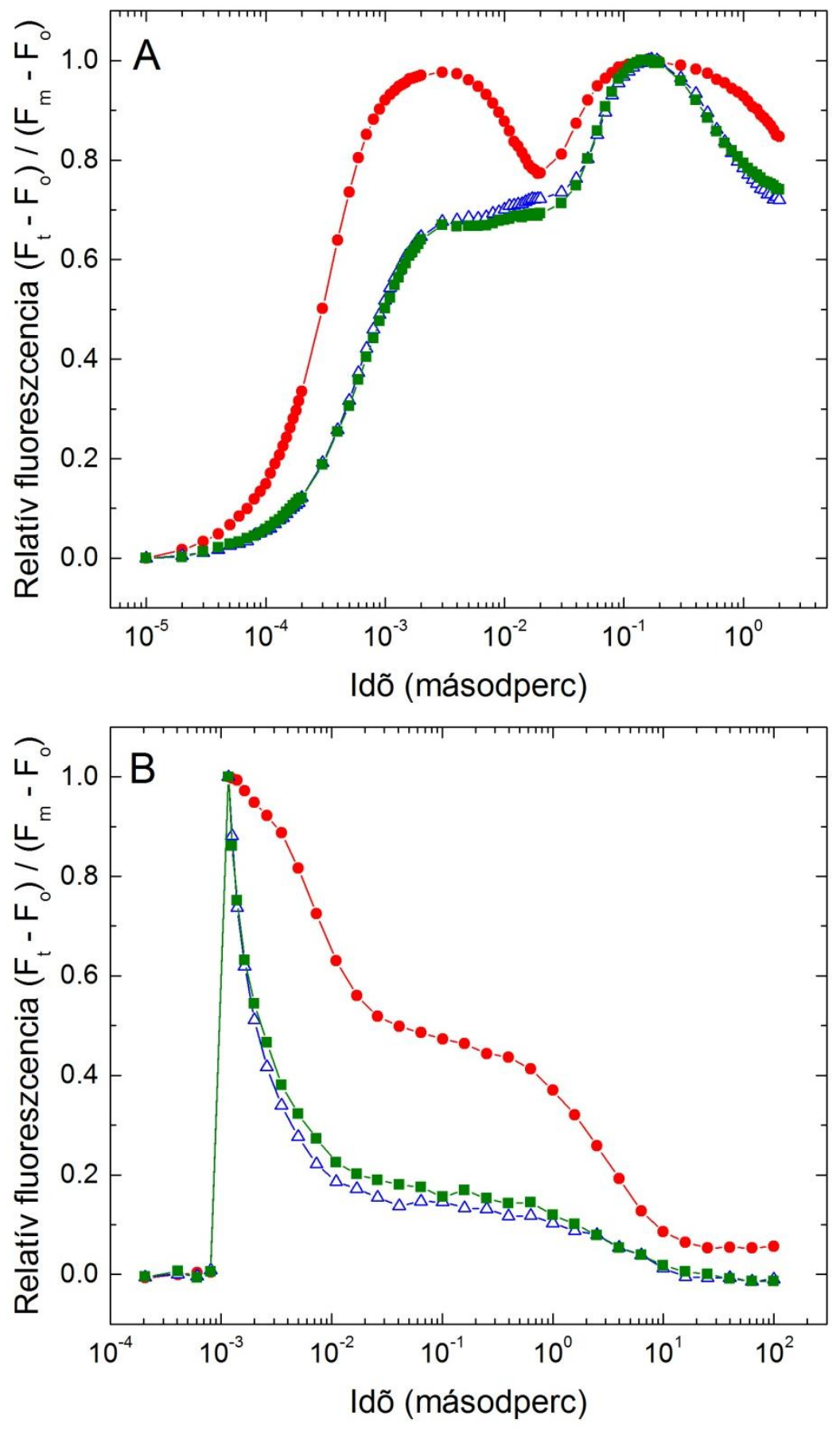

27. ábra: $\mathrm{Az}$ alga fotoszintetikus rendszerének fluoreszcenciás vizsgálata. A bakteriális partner által indukált anaerob körülmények hatása a Chlamydomonas sp. 549 gyors fluoreszcencia változásaira. Az OJIP tranziens (A panel) és a fényimpulzus-indukált fluoreszcencia hatásfok lecsengésének (B panel) görbéit a kevert alga-baktérium kultúrák (teli szimbólumok) és a tiszta alga kultúrák (üres szimbólumok) mérései adták. A kezeletlen kultúrák (piros kör) és a tíz perces levegő buborékoltatással kezelt kultúrák (zöld négyzet) méréseit 24 órával a leoltás után végeztük. A görbéket $F_{\mathrm{o}}$ és $F_{\mathrm{m}}$ értékek közé normalizáltuk. A 
kísérlethez kultúránként egy párhuzamos biológiai mintát használtunk és mindegyiken egy mérést végeztünk.

\subsubsection{A hidrogéntermelés kettős mechanizmusa}

A Chlamydomonas sp. 549 - E. coli $\triangle$ hypF kevert kultúra hidrogéntermelési mechanizmusának tanulmányozásához DCMU-t alkalmaztunk. A DCMU molekula blokkolja a PSII plasztokinon kötőhelyét, ezáltal megakadályozva az elektronok áramlását a PSII-ről a plasztokinonra. Vizsgálataink azt mutatták, hogy az etanolban oldott DCMU alkalmazásával az első nap során az alga hidrogéntermelésének intenzitása jelentősen csökkent. A Chlamydomonas sp. 549 - E. coli hypF kevert kultúra 2\% etanol mellett $3194.84 \pm 159.23 \mu \mathrm{L}$ $\mathrm{L}^{-1}$, míg az etanolban oldott DCMU-val kezelt ugyanezen kultúra $778.34 \pm 115.71 \mu \mathrm{L} \mathrm{L}^{-1}$ hidrogént termelt, úgy hogy a gátlószert két órás inkubáció után adtuk hozzá a mintákhoz. Ezen eredmények jól mutatják, hogy a teljes megtermelt hidrogénmennyiség meghatározó része fotolitikus forrásból származott. A hidrogén további része feltételezéseink szerint fermentatív útvonalakból származott, a pH eredmények (18. ábra) és az ecetsav mérések (17. ábra) ezt a feltételezést erősítik meg.

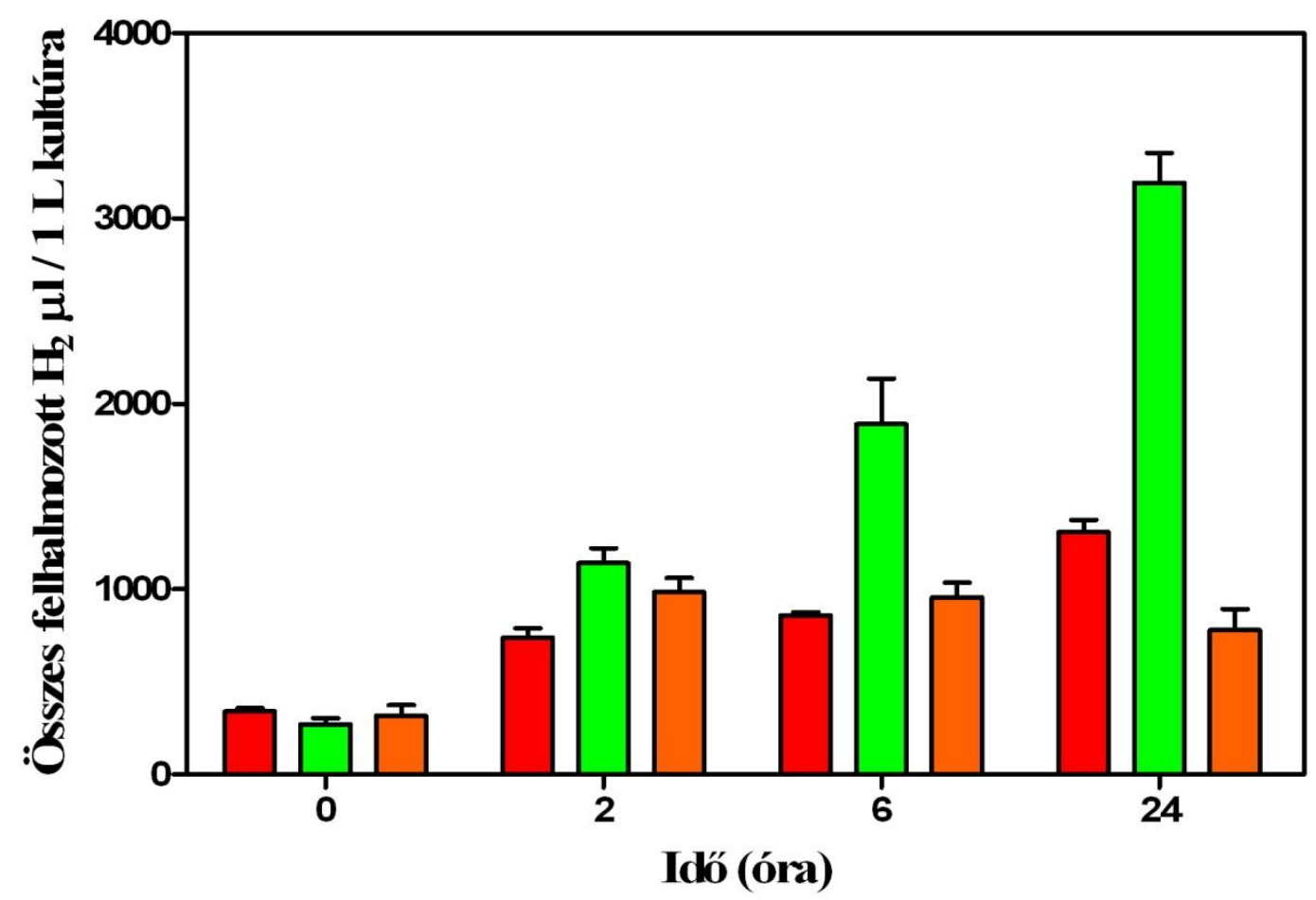

28. ábra: A Chlamydomonas sp. 549 hidrogéntermelési mechanizmusának meghatározása a fotoszintetikus rendszert gátló DCMU-val. TAP tápoldatban (piros oszlop), 2\% etanolt 
tartalmazó TAP tápoldatban (zöld oszlop) és $200 \mu$ mol DCMU-t tartalmazó TAP tápoldatban (narancssárga oszlop) inkubált Chlamydomonas sp. 549 - E. coli $\Delta$ hypF kevert kultúrák hidrogénhozamát hasonlítottuk össze. A kísérlethez kultúránként három párhuzamos biológiai mintát használtunk és mindegyiken három mérést végeztünk. A kapott adatokból átlagot és szórást számoltunk. 


\section{Az eredmények tárgyalása}

Munkánk során természetes (a Mosonmagyaróvári Alga Kultúra Gyüjteményben az alga kultúrák hosszú távú fenntartása során az alga mellett fennmaradt bakteriális partnerek) és mesterségesen hozzáadott bakteriális partnerek, az általunk választott Chlamydomonas alga törzs hidrogéntermelésére gyakorolt hatását vizsgáltuk. Megfigyeltük a tiszta alga és baktérium, illetve a kevert alga-baktérium kultúrák folyadék és gázfázisainak változásait. Jellegzetes trendeket fedeztünk fel a légtér gázösszetételében és az alga légzésének aktivitásában.

A Chlamydomonas kultúra növesztése és fenntartása során több különböző bakteriális kontaminációt azonosítottunk az alga mellett. A bakteriális partnereket egymástól elválasztottuk, majd azonosítottuk: Rhodococcus, Brevundimonas és Leifsonia nemzetségekbe tartozó törzseket azonosítottunk. Az azonosított baktérium törzseket jellemeztük a növekedési sebességük és az alga biomassza- és hidrogéntermelést elősegítő képességük alapján. A három természetes baktérium partner közül a Rhodococcus partnert találtuk a leginkább megfelelőnek a vizsgálataink elvégzéséhez. A természetes konzorciumok közül a Rhodococcus - Chlamydomonas sp. 549 kombináció termelte a legtöbb hidrogént. A természetes partnereken kívül más mesterségesen az algához adott bakteriális törzsek is képesek voltak csökkenteni a kultúra oxigénszintjét és tovább fokozni az alga hidrogéntermelését. Az E. coli $\Delta h y p F$ pleiotróp hidrogenáz mutáns használata eredményezte a kísérleteink során mért legnagyobb hidrogén hozamot (Maier és mtsai. 1996). A Chlamydomonas sp. 549 hidrogéntermelésének sajátosságait összehasonlítottuk a hidrogéntermelés modellorganizmusaként széles körben elterjedt $C h$. reinhardtii cc124 alga törzsével. A két algatörzs összehasonlítása mellett megvizsgáltuk a tiszta alga és kevert algabaktérium kultúrák hidrogéntermelését teljes (TAP) és az alga-alapú hidrogéntermelés viszonyítási alapját képező kénmegvonásos módszer kénmentes (TAP-S) tápoldatában. Jelentős különbségeket fedeztünk fel a különböző algatörzsek oxigénfogyasztásának intenzitásában, a hidrogéntermelés indulási idejében és időtartamában. A fényen inkubált kénmegvont axénikus $C h$. reinhardtii cc124 kultúrákban a teljes anaerobicitás eléréséhez 96 órára volt szükség. Ezzel szemben a baktériumot is tartalmazó kevert kultúrák légterében az oxigénszint 2-4 óra alatta csökkent olyan alacsony szintre, amely már lehetővé tette az alga hidrogenázainak müködését. Ez a jelenség a bakteriális partnereknek köszönhetően, függetlenül attól, hogy ként tartalmazó teljes vagy kénmentes tápba oltottuk-e le az alga- 
baktérium keveréket, minden esetben lejátszódott. Emellett a tiszta Chlamydomonas sp. 549 kultúra a kénmegvonás ellenére képtelen volt a hatékony hidrogéntermeléshez szükséges megfelelő szintig csökkenteni a légtér oxigénszintjét. A klorofill fluoreszcens méréseink alapján úgy gondoljuk, hogy a PSII aktivitása a Chlamydomonas sp. 549 esetében a $C h$. reinhardtii cc124 PSII aktivitásához viszonyítva lassabban csökken, amely jelentősen lassítja az alga oxigéntermelésének csökkenését, ezáltal késleltetve a hidrogéntermelés kezdeti időpontját (Scoma és mtsai. 2012). A vizsgálatok során világossá vált, hogy a két algatörzs eltérő hidrogéntermelési tulajdonságait az ecetsavfogyasztási sebességek és ezáltal az eltérő intenzitású sejtlégzések határozzák meg. A Chlamydomonas sp. 549 esetében az ecetsav az általunk preferált TAP tápoldatból körülbelül két nap után, míg a $C h$. reinhardtii cc124 esetében 5-6 nappal később fogyott el. Az ecetsav felhasználásának eltérő intenzitása a kénmegvonásos módszer használata során kritikus lehet. A Chlamydomonas sp. 549 II. fotokémiai rendszerének lassabb inaktiválódása és az algasejtek gyorsabb ecetsavfogyasztása miatt két nap után egy hozzávetőleg egy napos intenzív oxigéntermelő fázisba kerül, amely a zárt rendszert oxigénnel telíti és ezáltal hosszú távon gátolja a hidrogéntermelés beindulását. Ezek az adatok jól mutatják, hogy akár az egy nemzetségen belüli algák is jelentős különbséget mutathatnak a hidrogéntermelő képességük tekintetében (Skjanes és mtsai. 2008). Összességében, a Ch. reinhardtii cc124 a kénmegvonás során, a Chlamydomonas sp. 549-től eltérően, a hidrogéntermelő tulajdonságai alapján az általunk vártnak megfelelő eredményeket mutatott, ezzel is alátámasztva más kísérletek kénmegvonáson alapuló eredményeit (Zhang és mtsai. 2002) (4. táblázat).

\begin{tabular}{|c|c|c|c|c|}
\hline $\begin{array}{l}\text { Teljes } \\
\text { megtermelt } \\
\text { hidrogén } \\
\text { menniység }\end{array}$ & $\begin{array}{l}\text { Hidrogént } \\
\text { eremlés } \\
\text { kezdete }\end{array}$ & $\begin{array}{l}\text { Termelés } \\
\text { időtartama }\end{array}$ & Kísérletek beállításai & Referenciák \\
\hline $1.2 \mathrm{~mL} \mathrm{~L}^{-1}$ & 2-4 óra & 24 óra & $\begin{array}{l}\text { Tápoldat: TAP } \\
\text { Alga partner: } \\
\text { Chlamydomonas sp. } 549 \\
\text { Baktérium partner: E. coli } \\
\Delta h y p F \\
\text { Kultúra térfogata: } 35 \mathrm{~mL} \text {, } \\
\text { pH }=7.2 \text {, } \\
\text { Hömérséklet: } 25^{\circ} \mathrm{C} \\
\text { Fény intenzitás: } 50 \mu \mathrm{mol} \mathrm{m}{ }^{-2} \\
\mathrm{~s}^{-1}\end{array}$ & $\begin{array}{l}\text { Jelen } \\
\text { munka }\end{array}$ \\
\hline $2.6 \mathrm{~mL} \mathrm{~L}^{-1}$ & 2-4 óra & 72 óra & $\begin{array}{l}\text { Tápoldat: TAP } \\
\text { Alga partner: }\end{array}$ & $\begin{array}{l}\text { Jelen } \\
\text { munka }\end{array}$ \\
\hline
\end{tabular}




\begin{tabular}{|c|c|c|c|c|}
\hline & & & $\begin{array}{l}\text { Chlamydomonas sp. } 549 \\
\text { Baktérium partner: E. coli } \\
\text { \hypF } \\
\text { Kultúra térfogata: } 35 \mathrm{~mL} \\
\mathrm{pH}=7.2 \\
\text { Hömérséklet: } 25^{\circ} \mathrm{C} \\
\text { Fény intenzitás: } 50 \mu \mathrm{mol} \mathrm{m}{ }^{-2} \\
\mathrm{~s}^{-1}\end{array}$ & \\
\hline $5.8 \mathrm{~mL} \mathrm{~L}^{-1}$ & 2-4 óra & 24 óra & $\begin{array}{l}\text { Tápoldat: TAP } \\
\text { Alga partner: } \\
\text { Chlamydomonas reinhardtii } \\
\text { cc124 } \\
\text { Baktérium partner: E. coli } \\
\text { ShypF } \\
\text { Kultúra térfogata: } 35 \mathrm{~mL} \\
\text { pH }=7.2 \\
\text { Hömérséklet: } 25^{\circ} \mathrm{C} \\
\text { Fény intenzitás: } 50 \mu \mathrm{mol} \mathrm{m}{ }^{-2} \\
\mathrm{~s}^{-1}\end{array}$ & $\begin{array}{l}\text { Jelen } \\
\text { munka }\end{array}$ \\
\hline $47 \mathrm{~mL} \mathrm{~L}^{-1}$ & 2-4 óra & 168 óra & $\begin{array}{l}\text { Tápoldat: TAP-S } \\
\text { Alga partner: } \\
\text { Chlamydomonas reinhardtii } \\
\text { cc124 } \\
\text { Baktérium partner: E. coli } \\
\text { ShypF } \\
\text { Kultúra térfogata: } 35 \mathrm{~mL} \\
\text { pH }=7.2 \\
\text { Hömérséklet: } 25^{\circ} \mathrm{C} \\
\text { Fény intenzitás: } 50 \mu \mathrm{mol} \mathrm{m}{ }^{-2} \\
\mathrm{~s}^{-1}\end{array}$ & $\begin{array}{l}\text { Jelen } \\
\text { munka }\end{array}$ \\
\hline $85 \mathrm{~mL} \mathrm{~L}^{-1}$ & 46 óra & 140 óra & $\begin{array}{l}\text { Tápoldat: TAP-S } \\
\text { Alga partner: } \\
\text { Chlamydomonas reinhardtii } \\
\text { cc124 } \\
\text { Kultúra térfogata: } 1.2 \mathrm{~L} \\
\text { pH }=7.2 \\
\text { Hömérséklet: } 28^{\circ} \mathrm{C} \\
\text { Fény intenzitás: } 300 \mu \mathrm{mol} \mathrm{m}{ }^{-2} \\
\mathrm{~s}^{-1}\end{array}$ & $\begin{array}{l}\text { Tsygankov } \\
\text { és mtsai. } \\
2002\end{array}$ \\
\hline $71.6 \mathrm{~mL}$ & 32 óra & 140 óra & $\begin{array}{l}\text { Tápoldat: TAP-S } \\
\text { Alga partner: } \\
\text { Chlamydomonas reinhardtii } \\
\text { cc124 } \\
\text { Kultúra térfogata: } 1.2 \mathrm{~L} \\
\text { pH = } 7.2 \\
\text { Hőmérséklet: } 28^{\circ} \mathrm{C} \\
\text { Fény intenzitás: } 300 \mu \mathrm{mol} \mathrm{m}{ }^{-2} \\
\mathrm{~s}^{-1}\end{array}$ & $\begin{array}{l}\text { Tsygankov } \\
\text { és mtsai. } \\
2002\end{array}$ \\
\hline $56.4 \mathrm{~mL} \mathrm{~L}^{-1}$ & $\sim 90$ óra & $\sim 140$ óra & Tápoldat: TAP-S & Tsygankov \\
\hline
\end{tabular}




\begin{tabular}{|c|c|c|c|c|}
\hline & & & $\begin{array}{l}\text { Alga partner: } \\
\text { Chlamydomonas reinhardtii } \\
\text { cc124 } \\
\text { Kultúra térfogata } 550 \mathrm{~mL} \\
\text { pH }=7.4 \\
\text { Hőmérséklet: } 28^{\circ} \mathrm{C} \\
\text { Fény intenzitás: } 110 \mu \mathrm{mol} \mathrm{m}{ }^{-2} \\
\mathrm{~s}^{-1}\end{array}$ & $\begin{array}{l}\text { és mtsai. } \\
2006\end{array}$ \\
\hline $570.5 \mathrm{~mL} \mathrm{~L}^{-1}$ & 24 óra & 160 óra & $\begin{array}{l}\text { Tápoldat: TAP-S } \\
\text { Alga partner: } \\
\text { Chlamydomonas reinhardtii } \\
\text { L159I-N230Y } \\
\text { Kultúra térfogata: } 800 \mathrm{~mL} \\
\text { pH }=7.2 \\
\text { Hömérséklet: } 28^{\circ} \mathrm{C} \\
\text { Fény intenzitás: } 140 \mu \mathrm{mol} \mathrm{m}{ }^{-2} \\
\mathrm{~s}^{-1}\end{array}$ & $\begin{array}{l}\text { Scoma és } \\
\text { mtsai. } 2012\end{array}$ \\
\hline $262.0 \mathrm{~mL} \mathrm{~L}^{-1}$ & 24 óra & 80 óra & $\begin{array}{l}\text { Tápoldat: TAP-S } \\
\text { Alga partner: } \\
\text { Chlamydomonas reinhardtii } \\
\text { cc124 } \\
\text { Kultúra térfogata: } 800 \mathrm{~mL} \\
\text { pH }=7.2 \\
\text { Hömérséklet: } 28^{\circ} \mathrm{C} \\
\text { Fény intenzitás: } 140 \mu \mathrm{mol} \mathrm{m}{ }^{-2} \\
\mathrm{~s}^{-1}\end{array}$ & $\begin{array}{l}\text { Scoma és } \\
\text { mtsai. } 2012\end{array}$ \\
\hline $16.68 \mathrm{~mL} \mathrm{~L}^{-1}$ & $\begin{array}{l}\sim 24-48 \\
\text { óra }\end{array}$ & 312 óra & $\begin{array}{l}\text { Tápoldat: TAP-S } \\
\text { Alga partner: } \\
\text { Chlamydomonas reinhardtii } \\
\text { Cr849 } \\
\text { Baktérium partner: } \\
\text { Pseudomonas sp. A8 } \\
\text { Kultúra térfogata: } 40 \mathrm{~mL} \\
\text { pH = } 7.0 \\
\text { Hömérséklet: } 25^{\circ} \mathrm{C} \\
\text { Fény intenzitás: } 60 \mu \mathrm{E} \mathrm{m}{ }^{-2} \mathrm{~s}^{-1}\end{array}$ & $\begin{array}{l}\text { Li és mtsai. } \\
2013\end{array}$ \\
\hline
\end{tabular}

4. táblázat: Kevert alga-baktérium és tiszta alga kultúrák hidrogénteremlő módszereinek az összehasonlítása.

Az oxigénszintek változásaihoz hasonlóan az egyes kultúrák hidrogéntermelésében is jelentős különbségeket figyeltünk meg. A tiszta Ch. reinhardtii cc124 kultúrában megközelítőleg két nap után indult meg a hidrogéntermelés, míg a bakteriális partnert tartalmazó kultúrákban függetlenül attól, hogy teljes tápot vagy kénmentes tápot használtunk, a bakteriális légzés hatására már kettő-négy óra után elkezdődött a hidrogénfejlesztés. A termelés kezdőpontja és a termelt mennyiség mellett látványos különbséget mutatott a két törzs a hidrogéntermelés időtartamában is. A legnagyobb hatékonyságú hidrogéntermelést 
végül a két módszer együttes alkalmazásával sikerült elérnünk. A kénmegvonás során a bakteriális partnert tartalmazó Chlamydomonas sp. 549 három napig, míg a Ch. reinhardtii cc124 kultúra hét napig termelt hidrogént. A kevert Ch. reinhardtii cc124 - E. coli $\Delta$ hypF kultúra $47241.3 \pm 4660.69 \mu \mathrm{L} \mathrm{L}^{-1}$, míg a Chlamydomonas sp. 549 - E. coli $\Delta$ hypF kultúra $2637.49 \pm 555.42 \mu \mathrm{L} \mathrm{L}^{-1}$ hidrogént termelt a kísérlet időtartama alatt. A termelés időtartama mellett fontos megjegyeznünk, hogy a bakteriális partner jelenlétében a kénmegvonás során a kultúrák több hidrogént állítottak elő, mint a tiszta alga kultúrák (Wu és mtsai. 2012). A tiszta Ch. reinhardtii cc124 kultúra önmagában $25028.1 \pm 3943.47 \mu \mathrm{L} \mathrm{L}^{-1}$, míg kevert kultúrában $47241.3 \pm 4660.69 \mu \mathrm{L} \mathrm{L}^{-1}$ hidrogént fejlesztett. Ezek alapján jól látszik, hogy a bakteriális partnerek használata komoly elönyt jelenthet a jövőbeli ipari felhasználást tekintve. Az általunk preferált módszer a biohidrogén előállítás területén potenciális lehetőséget nyújt olyan hidrogenázzal rendelkező zöldalgák széleskörü alkalmazására, amelyeket eddig a kénmegvonással történő hidrogéntermeléshez szükséges speciális tulajdonságaik hiánya miatt nem lehetett bevonni biohidrogéntermelésbe. Emellett a bakteriális partnerek alkalmazása, bármiféle technikai beavatkozás nélkül lehetővé teszi a hidrogéntermelő közösségek gyorsabb oxigén felhasználását, a hidrogéntermelés elindítását és az összes megtermelt hidrogén mennyiségének a növelését.

Az előzőleg felsorolt előnyök mellett a módszernek ugyanakkor megvannak a hátrányai is. A hidrogéntermelés folyamata megfordítható reakció. Egy bizonyos, az alga típusától és a környezeti tulajdonságoktól függő parciális hidrogén nyomás felett a hidrogenázok hidrogéntermelő aktivitása lecsökken, majd megfordul (Kosourov és mtsai. 2012). Mindez egyaránt igaz az alga és a bakteriális partnerek hidrogenázaira is. A bakteriális partner esetében az E. coli $\triangle h y p F$ hidrogenáz mutáns törzs használatával ezt a problémát kiküszöböltük, viszont az alga partner képes volt a hidrogén felhasználására (Happe és mtsai. 1994). Ezt jól tükrözi az a jelenség, hogy a maximális hidrogénértékek elérése után a felhalmozódott hidrogén mennyisége csökkenni kezdett. Szintén problémát jelentett, hogy miután az oldatból elfogyott az ecetsav, az alga intenzív oxigéntermelésbe kezdett. Ez a jelenség egy-másfél napig tartott, viszont utána már a kultúra képtelen volt ismét anaerobbá válni. Ez két főbb okra vezethető vissza. Az egyik, hogy az ecetsav felhasználása során az alga sejtlégzése felgyorsul, amely elősegíti a fotoszintézis során keletkező oxigén felhasználását (Eppley és mtsai. 1963). Ecetsav hiányában viszont az alga sejtlégzésének hatásfoka jelentősen gyengébb és ez önmagában képtelen ismét anaerobbá alakítani a zárt kultúrát. A másik ok a bakteriális sejtszám és vele együtt a bakteriális légzés drasztikus 
csökkenése. A telepszám vizsgálatának eredményei alapján ezt két tényező befolyásolja. Az egyik a hidrogén túl magas parciális nyomásakor fellépő hidrogéngátlás, a másik az ecetsav hiány. Feltételezéseink szerint, amelynek bizonyításához a jövőben további vizsgálatok szükségesek, ezek együtt közvetett módon az alga által nyújtott tápanyagforrások változásával képesek befolyásolni a bakteriális sejtszámot. A hidrogéntermelés hidrogénfelvételbe fordulásakor az alga anyagcseréje megváltozik és innentől kezdve az alga nem juttat a környezetébe annyi, a bakteriális partner számára felvehető tápanyagot, amely mellett a baktérium kultúra képes lenne fenntartani a magas élő sejtszámot és biztosítani az oxigén gyors és hatékony felhasználását. Az ecetsav elfogyása és az alga sejtosztódás leállása után az élő bakteriális sejtszám szintén jelentős csökkenést mutat. A hidrogéntermelés mellett a hidrogén felhasználásában is jelentős különbségeket mutatott a két Chlamydomonas törzs. Mindkét alga megegyezett abban, hogy felhasználta az előzőleg megtermelt hidrogénjének egy részét, de a $C h$. reinhardtii cc124 esetében, mivel a lassabb sejtlégzés hatására az ecetsav mennyisége jóval tovább kitartott a Chlamydomonas sp. 549 kevert kultúrájához viszonyítva, újraindult a hidrogéntermelés.

A fotoszintetikus rendszer kulcsszerepet játszik a fényen történő hidrogéntermelésben. Ennek vizsgálatára klorofill fluoreszcencia méréseket végeztünk Chlamydomonas sp. 549-en. A kevert alga-baktérium kultúrákban megfigyeltük, hogy a plasztokinon molekulák nagy része redukált állapotba került. Az anaerob környezetben tartott minták OJIP görbéjének tulajdonságai megegyeztek az irodalmi adatokkal (Schansker és mtsai. 2005, Tóth és mtsai. 2006). A rövid ideig tartó levegővel történő átbuborékoltatás hatására az OJIP és a fényimpulzus-indukált floureszcencia lecsengés görbéi a tiszta alga kultúrákhoz hasonlóvá váltak. Mindez azt mutatta, hogy a TAP tápoldatban inkubált alga-baktérium mintákban a Chlamydomonas sp. 549 PSII-je intakt és teljesen aktív maradt. Ez teljesen ellentétben áll a kén-megvonás során megfigyelt redukált vagy inaktív állapotban lévő PSII-k állapotával. Ezek alapján az általunk alkalmazott hidrogéntermelési módszernek nem előfeltétele a PSII müködésének gátlása, viszont mindkét módszer képes javítani a másik hidrogéntermelési hatékonyságán.

A kénmegvonás mellett a sötét fermentáció módszere is kiemelkedő helyet foglal el az algával történő hidrogéntermelési technikák között. Viszont a kén-megvonással ellentétben, sötétben az alga hidrogéntermelésére csak minimális hatással volt a bakteriális partner jelenléte. A tiszta Chlamydomonas sp. 549 és a kevert, E. coli $\Delta$ hypF-et tartalmazó algakultúra teljes megtermelt hidrogénmennyisége minimálisan különbözött egymástól. 
Különbséget csak a kultúrák oxigénszintjének csökkenésében tapasztaltunk. A bakteriális partnert tartalmazó kultúra oxigénszintje gyorsabban csökkent, mint a tiszta alga kultúráé.

A méréseink során kapott adataink jól mutatják, hogy az aktív légzéssel rendelkező bakteriális közösségek jelenléte pozitív hatással van az alga biohidrogén fejlesztésére. Ezáltal az alga aktív fotoszintézise fontos szerepet kap a hidrogéntermelésben. Feltételezéseink szerint a bakteriális partnerek képesek felhasználni az alga által a fotoszintézis során termelt anyagokat, amelyek elősegítik a bakteriális kultúra fennmaradását és a teljes anaerobiózishoz szükséges intenzív bakteriális sejtlégzést. A bakteriális partner jelenléte mellett fontos szerepe van az alga által könnyen felhasználható szénforrásoknak. Jól mutatja ezt az ecetsav jelenlétének és hiányának a hidrogéntermelés szempontjából pozitív és negatív hatása. Az ecetsav-mentes kevert kultúrákra az oxigén magas koncentrációja miatt a hidrogéntermelés nem vagy csak minimális mértékben volt jellemző. A DCMU alkalmazása során kontrollként használt 2\% etanolt tartalmazó kultúrák hidrogéntermelése, összehasonlítva az etanol mentes TAP tápot tartalmazó kontroll minta hidrogén termelésével, szintén jól mutatja az oldott szénforrások kulcsszerepét.

Az eddig elért eredmények annak ellenére ígéretes alapját képezik egy új, alternatív biohidrogéntermelő módszernek, hogy a kapott megtermelt hidrogén mennyiségek még nem érik el más kutatott módszerek útján előállított hidrogén mennyiségeket. Az általunk vizsgált alga-baktérium konzorcium müködésének részletesebb megértéséhez és a hidrogéntermelés hatékonyságának növeléséhez további vizsgálatok szükségesek. Az anyagcsere folyamatok mélyebb megismeréséhez nyújthat segítséget a vegyes kultúrák szénhidrát, fehérje és lipid tartalmának vizsgálata, valamint a folyadékfázis összetételének részletes analitikai elemzése (Melis és mtsai. 2000). Az alga és baktérium partnerek teljes transzkriptom analízise lehetővé teheti számunkra, hogy nyomon kövessük az egyes partnerekben a hidrogéntermelés folyamata során aktívvá és inaktívvá váló anyagcsere útvonalakat (Nguyen és mtsai. 2008, Toepel és mtsai. 2013). A konzorcium működésének megismerése mellett további kutatások szükségesek ahhoz, hogy a rendszert képessé tegyük a későbbi ipari felhasználáshoz elengedhetetlenül szükséges folyamatos és hatékony hidrogéntermelésre. Komoly problémát okoz a légtérben gyorsan felgyülemlő hidrogén gátló hatása. A légtér térfogatának a megfelelő beállítása és a hidrogén eltávolítás ütemének a meghatározása feltételezéseink szerint orvosolná a hidrogéngátlás problémáját. Az ecetsav rendszeres adagolásával és alacsony ecetsav fogyasztású algatörzsek használatával elkerülhetővé válhatna a zárt kultúra gyors aerobizálódása. Feltételezéseink szerint az említett módszerek alkalmazásával 
megoldódna az anaerob környezet fenntartásáért felelős bakteriális partner sejtszámának az állandó magas szinten tartása és lehetővé válna egy félfolyamatos, hosszútávon hidrogéntermelésre képes rendszer megalkotása. 


\section{6. Összefoglalás}

Az ipari forradalom kezdete óta a fosszilis energiahordozók egyre nagyobb mértékü felhasználása miatt a légkör széndioxid tartalma fokozatosan növekedett. Fosszilis energiahordozóként kezdetben szenet használtak, majd az idő előrehaladtával egyre nagyobb szerepet kapott először az olaj, majd később a földgáz. Felhasználásuk mértéke napjainkban is fokozatosan növekszik. Használatuk az egyre nagyobb mennyiségü üvegházhatású széndioxid keletkezése mellett számos más problémát is felvet. A felhasználható források száma véges, viszont a felhasználás intenzitása hosszú távon folyamatosan növekszik. A források lelöhelye legtöbbször nem esik egybe a felhasználás helyével, további környezetszennyezési problémákat és geopolitikai kríziseket idézve elő. A felhasználásuk során nyert energia mennyisége nagymértékben meghatározza az egyes országok gazdasági teljesítőképességét. Ezért a gazdaság fokozatos fejlődéséhez és a lakosság életszínvonalának növekedéséhez elengedhetetlenül szükséges a felhasználási mennyiségük növelése.

A fosszilis energiahordozók részarányának csökkentésére és kiváltására számos alternatív módszer létezik. Napjainkban egyre gyorsabban terjednek a megújuló energiaforrásokat, mint a nap-, szél- és vízenergiahasznosító technológiák. Ezen technológiák egyik komoly hátránya, hogy az így termelt energiát nehéz tárolni, ezért jelentős részét rögtön fel kell használni. A megújuló energiaforrások tárolására nyújthat kiváló eszközt a molekuláris hidrogén használata, amelynek elégetése során melléktermékként csupán vízgőz keletkezik. Energiatároló kapacitása igen magas, egy grammja 122 kJ energiát képes raktározni. A szénhidrogén alapú üzemanyagokéhoz hasonlítva ez 2.75-ször nagyobb. Szállítása megoldható a már kiépített gázvezeték rendszereken keresztül. Tárolása nagynyomású tartályokban kivitelezhető. Üzemanyagként és fütőanyagként való felhasználása mellett még olajfinomításra, élelmiszeripari termékek előállítására, fémmegmunkálásra és mütrágya előállítására is alkalmazható. Előállítása történhet a víz elektrolízisével, viszont ez sok energiát igényel. Ezért napjainkban a hidrogén leginkább elterjedt előállítási módszere a gőzreformálás földgázból vagy metánból. Ezen technológia jövőbeli kiváltását célozza számos, jelenleg kutatási fázisban lévő biohidrogéntermelő módszer fejlesztése. Ezek közül biztató eredményeket mutatnak a zöldalgához köthető biohidrogén előállítással kapcsolatos kutatások.

A zöldalgák közül egyes Chlamydomonas, Scenedesmus és Chlorella fajokban megfelelő környezeti hatásokra FeFe hidrogenázok aktiválódnak. A FeFe hidrogenázok jó 
hatékonysággal, megközelítőleg 10\%-os konverzióval képesek a biohidrogén előállításra. Viszont jellemző rájuk az oxigénérzékenység, amely a direkt fotolízis útján történő folyamatos hidrogéntermelésnek komoly gátat szab. Erre kínál megoldást az indirekt fotolízis alkalmazása, melynek során először a fényből nyert energia elraktározódik, majd a tartalék tápanyagok lebontásával felhasználódik. Mindez lehetővé teszi az oxigén és hidrogéntermelés szakaszainak szétválasztását időben, és lehetőséget nyújt arra, hogy a tartalék tápanyagok lebontása során keletkező többlet elektronoktól a sejt a hidrogenázok által termelt hidrogén útján szabaduljon meg. Az indirekt fotolízis egyik leginkább ismert példája a kénmegvonáson alapuló hidrogéntermelés. A kénmegvonás során a zöldalga sejtek először tápanyagot halmoznak fel, majd a kénhiány hatására keményítő és fehérje tartalékaik lebontásába kezdenek a túlélésük érdekében. Ez a II. fotokémiai rendszer (PSII) aktivitásának csökkenésével jár, amely idővel ellehetetleníti a további oxigéntermelést. A csökkent oxigéntermelés és a fennmaradt sejtlégzés fordított aránya lehetővé teszi a zárt kultúra oxigénszintjének lecsökkenését, ezáltal elősegítve a hidrogenázok aktiválódását. A módszer hátránya, hogy először fel kell növeszteni az alga sejtkultúrát, majd a hidrogéntermeléshez ki kell cserélni a tápoldatot kénmentes tápoldatra. Ez a jövőbeli ipari alkalmazást tekintve komoly hátrányt jelent, mivel ez sok időt, többlet alapanyagot és energiát igényel. A hidrogéntermelő folyamat önmagában 5 nap után leáll, a meghosszabbított, de alacsonyabb hatásfokú termelés csak a kén kis mennyiségü újraadagolásával lehetséges. Ugyanakkor szintén jelentős időt vesz igénybe, amíg az oldat anaerobbá válik és megindul a hidrogéntermelés. Emellett a tápanyaghiány hatására az élő sejtek száma fokozatosan csökken.

Ezen problémák kiküszöbölésére kezdtünk el vizsgálni az általunk vizsgált alga törzsek közül egy kiváló biomassza hozamú Chlamydomonas törzset és annak természetes bakteriális partnereivel alkotott konzorciumának hidrogéntermelését. Az így kapott algabaktérium konzorciumokat számos módszerrel vizsgáltuk. A légtér hidrogén és oxigén szintjeinek változásait gázkromatográfiával követtük, míg a tápoldatban oldott oxigén monitorozásához oxigén elektródot használtunk. Lemezelésen alapuló élő sejtszám vizsgálatokat, Bürker-kamrát és spektrofotométert alkalmazva követtük az alga-baktérium konzorciumok sejtszám változásait. A tápoldatok minőség és mennyiségbeli változásainak vizsgálatához $\mathrm{pH}$ mérőt ás HPLC-t alkalmaztunk. A fotoszintetikus rendszer müködését DCMU alkalmazásával gátoltuk és klorofill fluoreszcencia mérésekkel követtük nyomon. A kísérletekhez használt természetes bakteriális partnereket rifampicinnel kiegészített minimál 
TP tápon többszörös átoltás után a legjobb biomassza hozammal rendelkező Chlamydomonas sp. 549 alga partnertől elválasztottuk, majd LB lemezen izoláltuk, hogy végül 16S rDNS szekvenciáik amplifikálásán alapuló polimeráz láncreakció (PCR) felhasználásával határozzuk meg nemzetségüket.

Teszteltük a három azonosított természetes bakteriális partner (Rhodococcus sp., Brevundimonas sp., Leifsonia sp.) hatását a Chlamydomonas sp. 549 sejtszám növekedésére és hidrogéntermelésére. A a három alga-baktérium keverék közül a legjobb eredményeket a Rhodococcus sp. - Chlamydomonas sp. 549 párosítás adta. Ezután vizsgálatainkat kibővítettük a mesterségesen a Chlamydomonas sp. 549 alga partnerhez adott Escherichia coli és Ralstonia eutropha vad típusú és hidrogenáz deficiens törzsekkel is. Az eredmények alapján kizártuk annak lehetőségét, hogy a bakteriális partnerek részt vesznek a hidrogéntermelésben, annak ellenére, hogy a vad típusú törzsek rendelkeznek saját hidrogenázokkal. A legmagasabb hidrogén hozamot a hidrogenáz deficiens $E$. coli $\triangle$ hypF mesterségesen hozzáadott bakteriális partner használatával értük el $\left(1196.06 \pm 4.42 \mu \mathrm{L} \mathrm{L}^{-1}\right)$. A Chlamydomonas sp. $549-$ E. coli $\triangle$ hypF kevert kultúra hidrogéntermelését összehasonlítottuk a kontrollként vizsgált $C h$. reinhardtii cc124 - E. coli $\triangle$ hypF kevert kultúráéval. A mérések során jelentős különbségeket figyeltünk meg nem csak a megtermelt hidrogénmennyiségek (Ch. reinhardtii cc124 - E. coli $\Delta$ hypF: $5800.54 \pm 65.73 \mu \mathrm{L} \mathrm{L}^{-1}$ vs. Chlamydomonas sp. $549-$ E. coli $\Delta$ hypF: $1196.06 \pm 4.42$ $\mu \mathrm{L} \mathrm{L}^{-1}$ ), de a termelés dinamikájának szempontjából is. A Chlamydomonas sp. $549-$ E. coli $\triangle h y p F$ és a $C h$. reinhardtii cc124 - E. coli $\triangle$ hypF kevert kultúrákban a hidrogéntermelés egyaránt megközelítőleg egy napig tartott, majd a légtérben felhalmozott hidrogén mennyisége csökkenésnek indult. Viszont a Ch. reinhardtii cc124 - E. coli $\Delta$ hypF esetében a negyedik nap után a hidrogéntermelés ismét elindult. Az oxigén szintje a bakteriális partner használata mellett jellemzően 4 órán belül lecsökkent arra a szintre (légtérben $3 \%$, folyadékban $1-2 \mu \mathrm{mol} \mathrm{L} \mathrm{L}^{-1}$ ), ahol a hidrogenázokat már nem gátolta. Az ecetsavfogyással összhangban, miután a kevert kultúrában a Chlamydomonas sp. 549 felhasználta az összes ecetsavat, az oxigénszint a második nap után intenzív emelkedésnek indult mind a folyadék fázisban (1 - $2 \mu \mathrm{mol} \mathrm{L}{ }^{-1}$-ről 1300 - $1600 \mu \mathrm{mol} \mathrm{L}{ }^{-1}$-re), mind pedig a légtérben (3\%-ról $60 \%$ ra). A pH szint az ecetsav fogyásával párhuzamosan növekedésnek indult és a kezdeti pH 7.3ról pH 8.7-re emelkedett. A Chlamydomonas sp. 549 sejtszáma fényen a tiszta és kevert kultúrákban egyaránt 4 napig emelkedett, de a kevert Chlamydomonas sp. 549 - E. coli $\triangle h y p F$ sejtszám növekedése gyorsabb volt a tiszta Chlamydomonas sp. 549 kultúráénál. A bakteriális sejtszámot a Rhodococcus sp.-t használva vizsgáltuk, melynek során arra a 
következtetésre jutottunk, hogy megvilágítás mellett a bakteriális sejtszámot pozitívan befolyásolta az alga partner jelenléte egészen addig, amíg a légtér nem telítődött hidrogénnel. A megvilágítás mellett egy napig magas szinten stagnáló bakteriális sejtszám az alga partner egy napig tartó hidrogéntermelésével mutatott összefüggést. A hidrogéntermelés leállásával és a hidrogénfogyással párhuzamosan a Rhodococcus sp. sejtszáma is drasztikus csökkenésnek indult.

Az alga-baktérium konzorcium hidrogéntermelő módszerét a kénmegvonás és a sötét fermentáció módszerével kombinálva is vizsgáltuk. A sötét fermentáció során a tiszta Chlamydomonas sp. 549 és a kevert Chlamydomonas sp. $549-$ E. coli $\Delta$ hypF kultúrák között az összes megtermelt hidrogén tekintetében nem találtunk szignifikáns különbséget (6114 \pm $369 \mu \mathrm{L} \mathrm{L}^{-1}$ vs. $5621 \pm 645 \mu \mathrm{L} \mathrm{L}^{-1}$ ). A kénmegvonás során összehasonlítottuk a tiszta Chlamydomonas sp. 549 és Ch. reinhardtii cc124 kultúrák és a kevert Chlamydomonas sp. 549 - E. coli $\triangle$ hypF és Ch. reinhardtii cc124 - E. coli $\Delta$ hypF kultúrák összes megtermelt hidrogén mennyiségét és a termelésük dinamikáját. Jelentős különbséget figyeltünk meg a tiszta és kevert kultúrák által termelt hidrogén mennyiségek között. Az E. coli $\Delta$ hypF bakteriális partnert tartalmazó kultúrák jellemzően több hidrogént termeltek, mint a kizárólag alga partnert tartalmazó kultúrák (Chlamydomonas sp. 549: $193.5 \pm 66.81 \mu \mathrm{L} \mathrm{L}^{-1}$ vs. Chlamydomonas sp. 549 - E. coli $\Delta$ hypF: $2637.49 \pm 555.42 \mu \mathrm{L} \mathrm{L}^{-1}$ és Ch. reinhardtii cc124: $25028.1 \pm 3943.47 \mu \mathrm{L} \mathrm{L}^{-1}$ vs. Ch. reinhardtii cc124 - E. coli $\Delta$ hypF: $47241.3 \pm 4660.69 \mu \mathrm{L}$ $\left.\mathrm{L}^{-1}\right)$. A kapott eredmények alapján úgy gondoljuk, hogy a hidrogéntermelésben történt pozitív változás a bakteriális partner jelenlétének köszönhető. Az összes megtermelt hidrogén mennyiségében, a légtér oxigénszint változásában és a hidrogéntermelés dinamikájában is jelentős különbséget fedeztünk fel a Chlamydomonas sp. 549 és a Ch. reinhardtii cc124 tiszta és kevert kultúrái között. A klorofill fluoreszcenciás mérések és az ecetsav koncentráció változásainak adatai alapján úgy gondoljuk, hogy ezt a különbséget a két algatörzs eltérő ecetsav felhasználása és a II. fotokémiai rendszerének inaktiválódási ideje határozta meg. A Chlamydomonas sp. 549 esetében a II. fotokémiai rendszer aktivitása a negyedik nap után kezdett el csökkenni, míg a Ch. reinhardtii cc124 esetében ez már az első nap folyamán elkezdődött. Az ecetsav koncentráció a sejtlégzések eltérő intenzitása miatt a Chlamydomonas sp. 549 esetében két nap alatt megközelítőleg 0-ra csökkent, míg a Ch. reinhardtii cc124 esetében ez 4 - 5 napig tartott. 
Az előbb bemutatott eredmények jól mutatják, hogy a hidrogéntermelés szempontjából mennyire meghatározó a megfelelő alga és baktérium partnerek kiválasztása. Az általunk vizsgált módszer kiváló lehetőséget ad a különböző bakteriális és hidrogenáz enzimmel rendelkező alga partnerek kombinálására a nagyobb hatékonyságú hidrogéntermelés eléréséhez. Figyelemre méltó előnye a rendszernek, hogy jelentősebb anyagi ráfordítást nem igénylő módon, külső beavatkozás nélkül, a zárt rendszer önmagát alakítja anaerobbá. A hidrogéntermelés során a biomassza mennyisége folyamatosan növekszik, amely egyre intenzívebbé teszi a hidrogéntermelést. Az alga kultúra jó hatékonysággal képes felhasználni az oldott szénforrást és képes a bakteriális sejtkultúra fenntartására alacsony erősségü megvilágítás mellett. Mindezen tulajdonságai alapján jó eséllyel adaptálható a módszer különböző oldott szénforrásokat és baktérium közösségeket tartalmazó szennyvizek kezeléséhez és az ezzel párhuzamos alga biomassza- és biohidrogéntermeléshez. 


\section{Summary}

Since the beginning of the industrial revolution, the carbon-dioxide content of the atmosphere has been continuously growing because of the rising utilization of fossil fuels. At the beginning coal was used as the dominan energy carrier, later crude oil and natural gas received more and more attention. Beside the problem of the growing amount of carbondioxide which is significantly responsible for the greenhouse effect, the utilization of these fossil fuels is connected to numerous other unsolved problems. The available sources of fossil fuels are limited, but the intensity of the consumption is continuously growing. The source and the site of utilization are mostly localized distantly, thereby causing further environmental pollution and geopolitical crisis. However, the extracted energy from their burning constitutes the essential part of the economies. Already many alternatives exist for the replacement of the fossil fuels. Nowadays, the technologies, which can put the renewable energy sources (sun, wind and water energy) to use, are getting more widespread. The cardinal drawback of these renewable technologies is the difficulty of energy storage. The utilization of the molecular hydrogen could provide an environmental friendly solution for the renewable energy storage. Its huge advantage is that during the burning of the hydrogen the only side-product is pure water. The hydrogen's energy storage capacity is very high, one gram hydrogen can store 122 $\mathrm{kJ}$ energy. It is 2.75 times higher than the yield stored by the fossil fuels. The large-scale transportation of the hydrogen gas is solvable by the utilization of the already existing systems. Moreover, it can be stored in metal gas bottles under high pressure. Beside the utilization as a fuel, it can be used for oil refinery, food and fertilizer production. Hydrogen can be generated in very high purity from water by electrolysis, but it consumes a lot of energy. Thus, nowadays it is produced from natural gas or methane by the technology of gas reforming. For the relay of this technology, many biohydrogen producing methods are currently under research and development. Among these investigations, the research of the biohydrogen production by green algae already shows promising results.

The FeFe hydrogenases can be activated under proper environmental conditions in certain Chlamydomonas, Scenedesmus and Chlorella species. The FeFe hydrogenases can convert the light energy into biohydrogen with $10 \%$ efficiency. However, they are highly sensitive for the presence of oxygen, which inhibits the continuous photolytic hydrogen production. The indirect photolysis can solve this problem by dissecting the hydrogen evolution and oxygen production phases. First, the energy of the illumination is stored in 
starch, then the starch is degraded and utilized. Thus, hydrogen evolution is separated from the photosynthetic oxygen production temporally. The most prevalent method of algal indirect photolytic hydrogen productions based on sulfur deprivation of the culture medium. During sulfur deprivation, the algae cells first accumulate carbohydrates and nutrients, then they start degrading their protein stores to survive the nutrient stress. It causes major reduction in the activity of the II. photochemical system (PSII), which finally inhibits further oxygen production of the algae cells. The reduced oxygen evolution and the active cell respiration allow the closed system to become anaerobic, thus enhancing the activation of hydrogenases. The major disadvantage of this method is that the algae cultures must be grown up first, then the original medium must be changed to a sulfur-free medium. This process definitely requires extra time, material and energy, which makes the starting of the industrial application more difficult. The hydrogen production process is an approximately five day-long period. The term of hydrogen evolution can be prolonged by the re-addition of sulfur for a few weeks, but it causes the reduction of the hydrogen production efficiency. The oxygen consumption period takes at least one day, which also reduces the industrial feasibility of the hydrogen production. Besides, the living cell number is continuously decreasing because of the nutritional stress effect.

Molecular- and microbiological methods and analytical tools were used for the investigations of the algal-bacterial mixture. Gas chromatography was used for the measurements of the hydrogen and oxygen concentrations in the headspace of the bottles. The dissolved oxygen content in the liquid phase of the cultures was measured by oxygen electrode. The living cell numbers of the bacterial partners were monitored by counting colony forming unit (CFU). The changes in the algae cell numbers were detected by the utilization of microscope and Bürker-chamber. The biomass productions of the certain pure and mixed cultures were followed by spectrophotometer. $\mathrm{pH}$ meter and HPLC were used for the investigation of the media. The alterations and functionality of the photosynthetic system was followed by chlorophyll fluorescent measurements. The Chlamydomonas sp. 549 strain was maintained on TP (Tris-Phosphate) plates supplemented with rifampicin, while the bacterial partners were separated and maintained on LB plates. Capillary Sanger sequencing of the bacterial 16S rDNA PCR products was used to identify the bacterial partners.

The effects of three natural bacterial partners (Rhodococcus sp., Brevundimonas sp., Leifsonia sp.) were tested on the biomass and hydrogen production of Chlamydomonas sp. 549. The highest biomass yields were obtained by the mixture of Rhodococcus sp. - 
Chlamydomonas sp. 549. The algal-bacterial investigations were broadened by adding wildtype and hydrogenase deficient Escherichia coli and Ralstonia eutropha bacterial strains to the algae culture as consortial partners. We clearly showed, that Chlamydomonas sp. 549 is the only hydrogen producer in the algal-bacterial consortium. The highest total accumulated hydrogen yield was achieved by the utilization of the hydrogenase deficient E. coli $\Delta$ hypF $\left(1196.06 \pm 4.42 \mu \mathrm{L} \mathrm{L}^{-1}\right)$.

The hydrogen evolution characteristics of Chlamydomonas sp. $549-$ E. coli $\Delta$ hypF and Ch. reinhardtii cc124 - E. coli $\triangle$ hypF mixed cultures were analysed. Significant differences were observed between the total accumulated hydrogen amounts $(C h$. reinhardtii cc124 - E. coli $\Delta$ hypF: $5800.54 \pm 65.73 \mu \mathrm{L} \mathrm{L}^{-1}$ vs. Chlamydomonas sp. $549-$ E. coli $\Delta$ hyp : $1196.06 \pm 4.42 \mu \mathrm{L} \mathrm{L}^{-1}$ ) and in the dynamics of hydrogen evolution as well. The hydrogen production lasted approximately $24 \mathrm{~h}$ in both Chlamydomonas sp. 549 - E. coli $\triangle$ hypF and Ch. reinhardtii cc124 - E. coli $\triangle$ hypF mixed cultures, then the hydrogen yields in the headspace started decreasing. In the case of the Ch. reinhardtii cc124 - E. coli $\Delta$ hypF mixed culture the hydrogen production re-started after the fourth day. The oxygen level in the cultures containing bacterial partner decreased in 4 hours to that level, where it could not inhibit the operation of the hydrogenases ( $3 \%$ in the headspace, $1-2 \mu \mathrm{mol} \mathrm{L}^{-1}$ in the liquid phase). In conjunction with the acetic acid consumption, which was consumed in 2 days by the mixed cultures, the oxygen level started increasing after the second day both in the liquid phase (from $1-2 \mu \mathrm{mol} \mathrm{L} \mathrm{L}^{-1}$ to $1300-1600 \mu \mathrm{mol} \mathrm{L}^{-1}$ ) and in the headspace (from $3 \%$ to $60 \%$ ). Parallel to the acetic acid consumption, the $\mathrm{pH}$ level increased from $\mathrm{pH} 7.3$ to $\mathrm{pH} 8.7$.

Under illumination, the increase of the Chlamydomonas sp. 549 cell number lasted 4 days, although a faster algal cell number increase was observed in the mixed Chlamydomonas sp. 549 - E. coli $\triangle$ hypF compared to the pure Chlamydomonas sp. 549 culture. The Rhodococcus sp. was chosen for the colony forming unit (CFU) investigations. The main conclusion of the CFU result was that the presence of the algal partner under illumination had a positive effect on bacterial living cell number until the headspace of the sealed bottle is saturated with hydrogen. In light circumstances, connection was observed between the high bacterial cell number and the algal hydrogen production in the mixed algal-bacterial cultures on the first day of the experiment. Along with the stop of algal hydrogen production, the living cell number of the Rhodococcus sp. was dramatically reduced. 
The algal-bacterial consortial hydrogen producing method was investigated in combined experiments with the hydrogen producing method of sulfur-deprivation and dark fermentation. No significant differences were observed in dark fermentative hydrogen production between the axenic Chlamydomonas sp. 549 and the mixed Chlamydomonas sp. 549 - E. coli $\Delta$ hypF cultures $\left(6114 \pm 369 \mu \mathrm{L} \mathrm{L}^{-1}\right.$ vs. $\left.5621 \pm 645 \mu \mathrm{L} \mathrm{L}^{-1}\right)$. The total accumulated hydrogen yield and the dynamics of the hydrogen production were compared in the sulfur-deprived Chlamydomonas sp. 549 and Ch. reinhardtii cc124 axenic cultures, and Chlamydomonas sp. $549-$ E. coli $\Delta$ hypF and Ch. reinhardtii cc124 - E. coli $\Delta$ hypF mixed cultures. Significant differences were detected between the total accumulated hydrogen yields of the pure algae and mixed algal-bacterial cultures. The mixed cultures containing E. coli $\triangle h y p F$ bacterial partner produced significantly more hydrogen than the pure algae cultures (Chlamydomonas sp. 549: $193.5 \pm 66.81 \mu \mathrm{L} \mathrm{L}^{-1}$ vs. Chlamydomonas sp. 549 - E. coli $\Delta$ hypF: $2637.49 \pm 555.42 \mu \mathrm{L} \mathrm{L}^{-1}$ and Ch. reinhardtii cc124: $25028.1 \pm 3943.47 \mu \mathrm{L} \mathrm{L}^{-1}$ vs. Ch. reinhardtii cc124 - E. coli $\Delta$ hypF: $47241.3 \pm 4660.69 \mu \mathrm{L} \mathrm{L}^{-1}$ ). Based on these results, it is hypothesized that the presence of the bacterial partner might have a positive effect on sulfurdeprived algal hydrogen production. Notable differences were observed in the total accumulated hydrogen yields, the oxygen level and in the dynamics of the hydrogen evolution between the sulfur-deprived pure and mixed cultures of both Chlamydomonas sp. 549 and Ch. reinhardtii cc124. The chlorophyll fluorescent measurements and acetic acid analyses suggested, that the different acetic acid consumption rates of the two algae strains and the decrease of the PSII activity are responsible for the observed variations. The activity of the PSII started to decrease after the fourth day in Chlamydomonas sp. 549, while in the case of the $C h$. reinhardtii cc124 the PSII activity already decreased on the first day of the experiment. The acetic acid was consumed in approximately two days by Chlamydomonas sp. 549, while total consumption of the acetic acid took four to five days for Ch. reinhardtii cc124.

The results showed the importance of the proper selection of the algae and bacterial partners for the most efficient hydrogen production. The investigated methods allow us to combine different bacterial and algal partners in order to achieve the highest biohydrogen output. A remarkable advantage of the approach is that it can reduce the oxygen level in a few hours without the need of any interventions. The amount of the algal biomass can continuously grow, which also accelerates the rate of the hydrogen production. In low light 
circumstances, the algal partner can consume the liquid carbon sources with good efficiency and maintain the bacterial partner with high living cell number. 


\section{Köszönetnyilvánítás}

Szeretném megköszönni témavezetőmnek Dr. Maróti Gergelynek a lehetőséget, hogy kutatócsoportjában elsajátíthattam a biotechnológiai és molekuláris biológiai technikákat és ismereteket. Hálás vagyok az irántam tanúsított bizalmáért és tanácsaiért, melyekkel önálló kutatómunkára ösztönzött. Köszönöm az áldozatos munkáját, mindenre kiterjedő nélkülözhetetlen segítségét és türelmét.

- Köszönöm Prof. Dr. Kondorosi Évának, hogy lehetővé tette számomra a kutatótevékenységében való részvételt és észrevételeivel segítette munkámat.

- Hálásan köszönöm Dr Rákhely Gábornak, hogy lehetővé tette számomra a laboratóriumi munkát és észrevételeivel segítette munkámat.

- Hálásan köszönöm Dr. Vass Imrének, hogy együttműködésével segítette laboratóriumi munkámat.

- Köszönet illeti Dr. Deák Zsuzsát a fluoreszcencia mérésekben nyújtott segítségéért.

- Köszönöm munkatársaimnak hogy mindig barátsággal fordultak hozzám.

- Köszönöm a segítségét a volt BayGen intézet valamennyi dolgozójának.

- Végtelen hálával tartozom családomnak az odaadó támogatásukért és végtelen türelmükért. 


\section{Irodalomjegyzék}

Afting, C., Hochheimer, A., \& Thauer, R. K. (1998). Function of H2-forming methylenetetrahydromethanopterin dehydrogenase from Methanobacterium thermoautotrophicum in coenzyme F420 reduction with $\mathrm{H}_{2}$. Archives of Microbiology, 169(3), 206-210.

Allakhverdiev, S. I., Thavasi, V., Kreslavski, V. D., Zharmukhamedov, S. K., Klimov, V. V., Ramakrishna, S., \& Carpentier, R. (2010). Photosynthetic hydrogen production. Journal of Photochemistry and Photobiology C: Photochemistry Reviews, 11(2), 101-113.

Antal, T. K., Krendeleva, T. E., Laurinavichene, T. V., Makarova, V. V., Ghirardi, M. L., Rubin, A. B., \& Seibert, M. (2003). The dependence of algal $\mathrm{H}_{2}$ production on Photosystem II and $\mathrm{O}_{2}$ consumption activities in sulfur-deprived Chlamydomonas reinhardtii cells. Biochimica et Biophysica Acta (BBA)-Bioenergetics, 1607(2), 153-160.

Beer, L. L., Boyd, E. S., Peters, J. W., \& Posewitz, M. C. (2009). Engineering algae for biohydrogen and biofuel production. Current Opinion in Biotechnology, 20(3), 264-271.

Berggren, G., Adamska, A., Lambertz, C., Simmons, T. R., Esselborn, J., Atta, M., ... \& Fontecave, M. (2013). Biomimetic assembly and activation of [FeFe]-hydrogenases. Nature, 499(7456), 66-69.

Bockris, J. O. (1975). Energy: the solar-hydrogen alternative.

Boichenko, V. A., Greenbaum, E. L. I. A. S., \& Seibert, M. I. C. H. A. E. L. (2004). Hydrogen production by photosynthetic microorganisms. Photoconversion of solar energy, molecular to global photosynthesis, 2, 397-452.

Brazilian Political Science Review, (2008). www.bpsr.org.br/index.php/bpsr/article/download/7/5

Burow, L. C., Woebken, D., Bebout, B. M., McMurdie, P. J., Singer, S. W., Pett-Ridge, J., \& Hoehler, T. M. (2011). Hydrogen production in photosynthetic microbial mats in the Elkhorn Slough estuary, Monterey Bay. The ISME journal, 6(4), 863-874.

Chen, H. C., \& Melis, A. (2004). Localization and function of SulP, a nuclear-encoded chloroplast sulfate permease in Ch. reinhardtii. Planta, 220(2), 198-210.

Chen, H. C., Newton, A. J., \& Melis, A. (2005). Role of SulP, a nuclear-encoded chloroplast sulfate permease, in sulfate transport and $\mathrm{H}_{2}$ evolution in Ch. reinhardtii. Photosynthesis Research, 84(1-3), 289-296.

Chen, H. C., Yokthongwattana, K., Newton, A. J., \& Melis, A. (2003). SulP, a nuclear gene encoding a putative chloroplast-targeted sulfate permease in Ch. reinhardtii. Planta, 218(1), 98-106. 
Chen, W. H., \& Syu, Y. J. (2010). Hydrogen production from water gas shift reaction in a high gravity (Higee) environment using a rotating packed bed. International Journal of Hydrogen Energy, 35(19), 10179-10189.

Christopher, K., \& Dimitrios, R. (2012). A review on exergy comparison of hydrogen production methods from renewable energy sources. Energy \& Environmental Science, 5(5), 6640-6651.

Cohen, S. S. (1949). Adaptive enzyme formation in the study of uronic acid utilization by the K-12 strain of Escherichia coli. Journal of Biological Chemistry, 177(2), 607-619.

Doebbe, A., Keck, M., La Russa, M., Mussgnug, J. H., Hankamer, B., Tekçe, E., \& Kruse, O. (2010). The interplay of proton, electron, and metabolite supply for photosynthetic $\mathrm{H}_{2}$ production in Ch. reinhardtii. Journal of Biological Chemistry, 285(39), 30247-30260.

Encyclopaedia Britannica (2001) Incorporated, 15th edn; Wilson, S.S. (1981) Spektrum der Wissenschaft, pp. 99-109 (Okt. 1981)

Eppley, R. W., Gee, R., \& Saltman, P. (1963). Photometabolism of acetate by Chlamydomonas mundana. Physiologia Plantarum, 16(4), 777-792.

Fedorov, A. S., Kosourov, S., Ghirardi, M. L., \& Seibert, M. (2005, January). Continuous hydrogen photoproduction by Ch. reinhardtii. In Twenty-Sixth Symposium on Biotechnology for Fuels and Chemicals (pp. 403-412). Humana Press.

Florin, L., Tsokoglou, A., \& Happe, T. (2001). A novel type of iron hydrogenase in the green alga Scenedesmus obliquus is linked to the photosynthetic electron transport chain. Journal of Biological Chemistry, 276(9), 6125-6132.

Fontecilla-Camps, J. C., Volbeda, A., Cavazza, C., \& Nicolet, Y. (2007). Structure/function relationships of [NiFe]-and [FeFe]-hydrogenases. Chemical reviews, 107(10), 4273-4303.

Forestier, M., King, P., Zhang, L., Posewitz, M., Schwarzer, S., Happe, T., \& Seibert, M. (2003). Expression of two [Fe]-hydrogenases in Chlamydomonas reinhardtii under anaerobic conditions. European Journal of Biochemistry, 270(13), 2750-2758.

Fouchard, S., Hemschemeier, A., Caruana, A., Pruvost, J., Legrand, J., Happe, T., \& Cournac, L. (2005). Autotrophic and mixotrophic hydrogen photoproduction in sulfur-deprived Chlamydomonas cells. Applied and Environmental Microbiology, 71(10), 6199-6205.

Gaffron, H., \& Rubin, J. (1942). Fermentative and photochemical production of hydrogen in algae. The Journal of General Physiology, 26(2), 219-240.

Gest, H., \& Kamen, M. D. (1949). Studies in the metabolism of photosynthetic bacteria IV.: Photochemical Production of Molecular Hydrogen by Growing Cultures of Photosynthetic Bacteria. Journal of Bacteriology, 58(2), 239. 
Gfeller, R. P., \& Gibbs, M. (1984). Fermentative metabolism of Chlamydomonas reinhardtii I. Analysis of fermentative products from starch in dark and light. Plant Physiology, 75(1), 212-218.

Ghirardi, M. L., Cohen, J., King, P., Schulten, K., Kim, K., \& Seibert, M. (2006, August). [FeFe]-hydrogenases and photobiological hydrogen production. In SPIE Optics+ Photonics (pp. 63400X-63400X). International Society for Optics and Photonics.

Ghirardi, M. L., Posewitz, M. C., Maness, P. C., Dubini, A., Yu, J., \& Seibert, M. (2007). Hydrogenases and Hydrogen Photoproduction in Oxygenic Photosynthetic Organisms*. Annual Review of Plant Biology, 58, 71-91.

Ghirardi, M. L., Zhang, L., Lee, J. W., Flynn, T., Seibert, M., Greenbaum, E., \& Melis, A. (2000). Microalgae: a green source of renewable $\mathrm{H}_{2}$. Trends in Biotechnology, 18(12), 506511.

Gorman, D. S., \& Levine, R. P. (1965). Cytochrome f and plastocyanin: their sequence in the photosynthetic electron transport chain of Chlamydomonas reinhardi. Proceedings of the National Academy of Sciences of the United States of America, 54(6), 1665.

Green, M. R., \& Sambrook, J. (2012). Molecular cloning: a laboratory manual (pp. 65-73). New York: Cold Spring Harbor Laboratory Press.

Greenbaum, E., Guillard, R. R. L., \& Sunda, W. G. (1983). Hydrogen and oxygen photoproduction by marine algae. Photochemistry and Photobiology, 37(6), 649-655.

Hall, C., Tharakan, P., Hallock, J., Cleveland, C., \& Jefferson, M. (2003). Hydrocarbons and the evolution of human culture. Nature, 426(6964), 318-322.

Hankamer, B., Lehr, F., Rupprecht, J., Mussgnug, J. H., Posten, C., \& Kruse, O. (2007). Photosynthetic biomass and $\mathrm{H}_{2}$ production by green algae: from bioengineering to bioreactor scale-up. Physiologia Plantarum, 131(1), 10-21.

Happe, R. P., Roseboom, W., Pierik, A. J., Albracht, S. P., \& Bagley, K. A. (1997). Biological activation of hydrogen. Nature, (385), 126-126.

Happe, T., Hemschemeier, A., Winkler, M., \& Kaminski, A. (2002). Hydrogenases in green algae: do they save the algae's life and solve our energy problems? Trends in Plant Science, $7(6), 246-250$.

Happe, T., \& Kaminski, A. (2002). Differential regulation of the Fe-hydrogenase during anaerobic adaptation in the green alga Chlamydomonas reinhardtii. European Journal of Biochemistry, 269(3), 1022-1032.

Happe, T., Mosler, B., \& Naber, J. D. (1994). Induction, localization and metal content of hydrogenase in the green alga Chlamydomonas reinhardtii. European Journal of Biochemistry, 222(3), 769-774.

Harris, E. H. (1989). The chlamydomonas sourcebook (Vol. 2). San Diego: Academic Press. 
Hartmann, G. C., Klein, A. R., Linder, M., \& Thauer, R. K. (1996). Purification, properties and primary structure of $\mathrm{H}_{2}$-forming $\mathrm{N} \quad 5$, N10-methylenetetrahydromethanopterin dehydrogenase from Methanococcus thermolithotrophicus. Archives of Microbiology, 165(3), 187-193.

Hemschemeier, A., \& Happe, T. (2005). The exceptional photofermentative hydrogen metabolism of the green alga Chlamydomonas reinhardtii. Biochemical Society Transactions, 33(1), 39-41.

Holzenburg, A., Mayer, F., Harauz, G., Van Heel, M., Tokuoka, R., Ishida, T., \& Saenger, W. (1987). Structure of D-ribulose-1, 5-bisphosphate carboxylase/oxygenase from Alcaligenes eutrophyus $\mathrm{H} 16$.

Hutner, S. H., Provasoli, L., Schatz, A., \& Haskins, C. P. (1950). Some approaches to the study of the role of metals in the metabolism of microorganisms. Proceedings of the American Philosophical Society, 152-170.

International Energy Agency (IEA), 2002 Key World Energy Statistics, 2002

International Energy Agency (IEA), 2008. Key World Energy Statistics 2008

IPCC, 2006. IPCC guidelines for national greenhouse gas inventories. Prepared by the National Greenhouse Gas Inventories Programme (Eggleston, H.S., Buendia, L., Miwa, K., Ngara, T., Tanabe, K., Eds.). IGES, Japan.

Joliot, A. Joliot. P.(1964) Comptes rendus hebdomadaires des séances de l'Académie des sciences, 258, 4622-4625.

Jordan, P., Fromme, P., Witt, H. T., Klukas, O., Saenger, W., \& Krauß, N. (2001). Threedimensional structure of cyanobacterial photosystem I at $2.5 \AA$ resolution. Nature, 411(6840), 909-917.

Jordan, R., Nessau, U., \& Schlodder, E. (1998). Charge recombination between the reduced iron-sulphur clusters and $\mathrm{P} 700^{+}$. In Photosynthesis: mechanisms and effects (pp. 663-666). Springer Netherlands.

Kawaguchi, H., Hashimoto, K., Hirata, K., \& Miyamoto, K. (2001). $\mathrm{H}_{2}$ production from algal biomass by a mixed culture of Rhodobium marinum A-501 and Lactobacillus amylovorus. Journal of Bioscience and Bioengineering, 91(3), 277-282.

Kim, M. S., Baek, J. S., Yun, Y. S., Jun Sim, S., Park, S., \& Kim, S. C. (2006). Hydrogen production from Chlamydomonas reinhardtii biomass using a two-step conversion process: Anaerobic conversion and photosynthetic fermentation. International Journal of Hydrogen Energy, 31(6), 812-816.

Kosourov, S. N., Batyrova, K. A., Petushkova, E. P., Tsygankov, A. A., Ghirardi, M. L., \& Seibert, M. (2012). Maximizing the hydrogen photoproduction yields in Chlamydomonas 
reinhardtii cultures: the effect of the $\mathrm{H}_{2}$ partial pressure. International Journal of Hydrogen Energy, 37(10), 8850-8858.

Kosourov, S. N., Ghirardi, M. L., \& Seibert, M. (2011). A truncated antenna mutant of Chlamydomonas reinhardtii can produce more hydrogen than the parental strain. International Journal of Hydrogen Energy, 36(3), 2044-2048.

Kosourov, S., Seibert, M., \& Ghirardi, M. L. (2003). Effects of extracellular pH on the metabolic pathways in sulfur-deprived, $\mathrm{H}_{2}$-producing Chlamydomonas reinhardtii cultures. Plant and Cell Physiology, 44(2), 146-155.

Kotai, J. (1972). Instructions for preparation of modified nutrient solution Z8 for algae. Norwegian Institute for Water Research, Oslo, 11(69), 5.

Kovács, K. L., Maróti, G., \& Rákhely, G. (2006). A novel approach for biohydrogen production. International Journal of Hydrogen Energy, 31(11), 1460-1468.

Krabben, L., Schlodder, E., Jordan, R., Carbonera, D., Giacometti, G., Lee, H., \& Lubitz, W. (2000). Influence of the axial ligands on the spectral properties of P700 of photosystem I: a study of site-directed mutants. Biochemistry, 39(42), 13012-13025.

Krassen, H., Schwarze, A., Friedrich, B., Ataka, K., Lenz, O., \& Heberle, J. (2009). Photosynthetic hydrogen production by a hybrid complex of photosystem I and [NiFe]hydrogenase. ACS Nano, 3(12), 4055-4061.

Kreuzberg, K. (1984). Starch fermentation via a formate producing pathway in Chlamydomonas reinhardii, Chlorogonium elongatum and Chlorella fusca. Physiologia Plantarum, 61(1), 87-94.

Kruse, O., \& Hankamer, B. (2010). Microalgal hydrogen production. Current Opinion in Biotechnology, 21(3), 238-243.

Kruse, O., Rupprecht, J., Bader, K. P., Thomas-Hall, S., Schenk, P. M., Finazzi, G., \& Hankamer, B. (2005). Improved photobiological $\mathrm{H}_{2}$ production in engineered green algal cells. Journal of Biological Chemistry, 280(40), 34170-34177.

Kuhl, A. (1962) Zur phsiologie der Speicherung Kondensierter anorganisher phospahte in Chlorella. Vortag Bot. Hrsg. Deut. Botan. Ges. (N.C.), 1, 157-166.

Kundu, S., Trent III, J. T., \& Hargrove, M. S. (2003). Plants, humans and hemoglobins. Trends in Plant Science, 8(8), 387-393.

Laurinavichene, T. V., Fedorov, A. S., Ghirardi, M. L., Seibert, M., \& Tsygankov, A. A. (2006). Demonstration of sustained hydrogen photoproduction by immobilized, sulfurdeprived Chlamydomonas reinhardtii cells. International Journal of Hydrogen Energy, 31(5), 659-667. 
Li, X., Huang, S., Yu, J., Wang, Q., \& Wu, S. (2013). Improvement of hydrogen production of Chlamydomonas reinhardtii by co-cultivation with isolated bacteria. International Journal of Hydrogen Energy, 38(25), 10779-10787.

Lipman, T., (2011) An overview of hydrogen production and storage systems with renewable hydrogen case studies. In: Energy Efficiency and Renewable Energy Fuel Cell Technologies Program (US DOE Grant DE-FC3608GO18111A000).

Maier, T., Binder, U., \& Böck, A. (1996). Analysis of the hydA locus of Escherichia coli: two genes (hydN and hypF) involved in formate and hydrogen metabolism. Archives of Microbiology, 165(5), 333-341.

Manish, S., \& Banerjee, R. (2008). Comparison of biohydrogen production processes. International Journal of Hydrogen Energy, 33(1), 279-286.

Markets and Markets, 2011. Hydrogen Generation Market-by Merchant \& Captive Type, Distributed \& Centralized Generation, Application \& Technology-Trends \& Global Forecasts (2011-2016). Report code: EP1708. http://www.marketsandmarkets.com/MarketReports/hydrogen-generation-market-494.html.

Martin-Amouroux, J.-M. (2003) IEPE, Grenoble, France, BP Statistical Review of World Energy (2004) United Kingdom.

Melis, A. (2007). Photosynthetic $\mathrm{H}_{2}$ metabolism in Chlamydomonas reinhardtii (unicellular green algae). Planta, 226(5), 1075-1086.

Melis, A., \& Happe, T. (2001). Hydrogen production. Green algae as a source of energy. Plant Physiology, 127(3), 740-748.

Melis, A., \& Melnicki, M. R. (2006). Integrated biological hydrogen production. International Journal of Hydrogen Energy, 31(11), 1563-1573.

Melis, A., Neidhardt, J., \& Benemann, J. R. (1998). Dunaliella salina (Chlorophyta) with small chlorophyll antenna sizes exhibit higher photosynthetic productivities and photon use efficiencies than normally pigmented cells. Journal of Applied Phycology, 10(6), 515-525.

Melis, A., Seibert, M., \& Happe, T. (2004). Genomics of green algal hydrogen research. Photosynthesis Research, 82(3), 277-288.

Melis, A., Zhang, L., Forestier, M., Ghirardi, M. L., \& Seibert, M. (2000). Sustained photobiological hydrogen gas production upon reversible inactivation of oxygen evolution in the green alga Chlamydomonas reinhardtii. Plant Physiology, 122(1), 127-136.

Metz, J. G., Pakrasi, H. B., Seibert, M., \& Arntzer, C. J. (1986). Evidence for a dual function of the herbicide-binding D1 protein in photosystem II. FEBS letters, 205(2), 269-274.

Moseley, J., Quinn, J., Eriksson, M., \& Merchant, S. (2000). The Crd1 gene encodes a putative di-iron enzyme required for photosystem I accumulation in copper deficiency and hypoxia in Chlamydomonas reinhardtii. The EMBO journal, 19(10), 2139-2151. 
Mus, F., Dubini, A., Seibert, M., Posewitz, M. C., \& Grossman, A. R. (2007). Anaerobic acclimation in Chlamydomonas reinhardtii anoxic gene expression, hydrogenase induction, and metabolic pathways. Journal of Biological Chemistry, 282(35), 25475-25486.

Nguyen, A. V., Thomas-Hall, S. R., Malnoë, A., Timmins, M., Mussgnug, J. H., Rupprecht, J., \& Schenk, P. M. (2008). Transcriptome for photobiological hydrogen production induced by sulfur deprivation in the green alga Chlamydomonas reinhardtii. Eukaryotic cell, 7(11), 1965-1979.

Nicolet, Y., Piras, C., Legrand, P., Hatchikian, C. E., \& Fontecilla-Camps, J. C. (1999). Desulfovibrio desulfuricans iron hydrogenase: the structure shows unusual coordination to an active site Fe binuclear center. Structure, 7(1), 13-23.

Nouni, M. R. (2012). Hydrogen energy and fuel cell technology: Recent developments and future prospects in India. Renewable Energy-Akshay Urja 5(5), 10-14.

Ohta, S., Miyamoto, K., \& Miura, Y. (1987). Hydrogen evolution as a consumption mode of reducing equivalents in green algal fermentation. Plant Physiology, 83(4), 1022-1026.

Pandey, A., Lee, D. J., Chisti, Y., \& Soccol, C. R. (Eds.). (2013). Biofuels from algae. Newnes.

Papageorgiou, G. C., Govindjee (Eds.). (2004). Chlorophyll a fluorescence: a signature of photosynthesis (Vol. 19). Springer.

Papageorgiou, G. C., Tsimilli-Michael, M., \& Stamatakis, K. (2007). The fast and slow kinetics of chlorophyll a fluorescence induction in plants, algae and cyanobacteria: a viewpoint. Photosynthesis Research, 94(2-3), 275-290.

Perreault, F., Ait Ali, N., Saison, C., Popovic, R., \& Juneau, P. (2009). Dichromate effect on energy dissipation of photosystem II and photosystem I in Chlamydomonas reinhardtii. Journal of Photochemistry and Photobiology B: Biology, 96(1), 24-29.

Peters, J. W. (1999). Structure and mechanism of iron-only hydrogenases. Current Opinion in Structural Biology, 9(6), 670-676.

Peters, J. W., Lanzilotta, W. N., Lemon, B. J., \& Seefeldt, L. C. (1998). X-ray crystal structure of the Fe-only hydrogenase $(\mathrm{CpI})$ from Clostridium pasteurianum to 1.8 angstrom resolution. Science, 282(5395), 1853-1858.

Pierik, A. J., Roseboom, W., Happe, R. P., Bagley, K. A., \& Albracht, S. P. (1999). Carbon monoxide and cyanide as intrinsic ligands to iron in the active site of [NiFe]-hydrogenases $\mathrm{NiFe}(\mathrm{CN})$ 2CO, Biology's way to activate $\mathrm{H}_{2}$. Journal of Biological Chemistry, 274(6), 3331-3337.

Posewitz, M. C., King, P. W., Smolinski, S. L., Zhang, L., Seibert, M., \& Ghirardi, M. L. (2004). Discovery of two novel radical S-adenosylmethionine proteins required for the 
assembly of an active [Fe] hydrogenase. Journal of Biological Chemistry, 279(24), 2571125720 .

Quinn, J. M., Eriksson, M., Moseley, J. L., \& Merchant, S. (2002). Oxygen deficiency responsive gene expression in Chlamydomonas reinhardtii through a copper-sensing signal transduction pathway. Plant Physiology, 128(2), 463-471.

Razeghifard, R. (2013). Algal biofuels. Photosynthesis Research, 117(1-3), 207-219.

Rubach, J. K., Brazzolotto, X., Gaillard, J., \& Fontecave, M. (2005). Biochemical characterization of the HydE and HydG iron-only hydrogenase maturation enzymes from Thermatoga maritima. FEBS Letters, 579(22), 5055-5060.

Sambrook, J., Russell, D. W., \& Russell, D. W. (2001). Molecular cloning: a laboratory manual (3-volume set) (Vol. 999). Cold Spring Harbor, New York: Cold Spring Harbor Laboratory Press.

Schansker, G., Tóth, S. Z., \& Strasser, R. J. (2005). Methylviologen and dibromothymoquinone treatments of pea leaves reveal the role of photosystem I in the Chl $a$ fluorescence rise OJIP. Biochimica et Biophysica Acta (BBA)-Bioenergetics, 1706(3), 250261.

Schreiber, U., Schliwa, U., \& Bilger, W. (1986). Continuous recording of photochemical and non-photochemical chlorophyll fluorescence quenching with a new type of modulation fluorometer. Photosynthesis Research, 10(1-2), 51-62.

Schütz, K., Happe, T., Troshina, O., Lindblad, P., Leitão, E., Oliveira, P., \& Tamagnini, P. (2004). Cyanobacterial $\mathrm{H}_{2}$ production — a comparative analysis. Planta, 218(3), 350-359.

Scoma, A., Krawietz, D., Faraloni, C., Giannelli, L., Happe, T., \& Torzillo, G. (2012). Sustained $\mathrm{H}_{2}$ production in a Chlamydomonas reinhardtii D1 protein mutant. Journal of Biotechnology, 157(4), 613-619.

Seibert, M., King, P. W., Posewitz, M. C., Melis, A., Ghirardi, M. L., Wall, J. D., \& Demain, A. (2008). Photosynthetic water-splitting for hydrogen production. In Bioenergy (pp. 273291). ASM Press.

Sen, U., Shakdwipee, M., \& Banerjee, R. (2008). Status of biological hydrogen production. Journal of Scientific and Industrial Research, 67(11), 980.

Skjånes, K., Knutsen, G., Källqvist, T., \& Lindblad, P. (2008). $\mathrm{H}_{2}$ production from marine and freshwater species of green algae during sulfur deprivation and considerations for bioreactor design. International journal of hydrogen energy, 33(2), 511-521.

Sorensen, B. (2005). Hydrogen and Fuel Cells: Emerging technologies and applications. Academic Press.

Spruit, C. J. P. (1958). Simultaneous photoproduction of hydrogen and oxygen by Chlorella. Meded. van de Landbou Wageningen, 58, 1-17. 
Strasser, R. J., \& Srivastava, A. (1995). Polyphasic chlorophyll a fluorescence transient in plants and cyanobacteria. Photochemistry and Photobiology, 61(1), 32-42.

Sueoka, N. (1960). Mitotic replication of deoxyribonucleic acid in Chlamydomonas reinhardtii. Proceedings of the National Academy of Sciences of the United States of America, 46(1), 83.

Tóth, S. Z., Schansker, G., \& Strasser, R. J. (2007). A non-invasive assay of the plastoquinone pool redox state based on the OJIP-transient. Photosynthesis research, 93(1-3), 193-203.

Thauer, R. K., Klein, A. R., \& Hartmann, G. C. (1996). Reactions with molecular hydrogen in microorganisms: evidence for a purely organic hydrogenation catalyst. Chemical Reviews, 96(7), 3031-3042.

Toepel, J., Illmer-Kephalides, M., Jaenicke, S., Straube, J., May, P., Goesmann, A., \& Kruse, O. (2013). New insights into Chlamydomonas reinhardtii hydrogen production processes by combined microarray/RNA-seq transcriptomics. Plant biotechnology journal, 11(6), 717-733.

Trtílek, M., Kramer, D. M., Koblížek, M., \& Nedbal, L. (1997). Dual-modulation LED kinetic fluorometer. Journal of Luminescence, 72, 597-599.

Tsimilli-Michael, M., Stamatakis, K., \& Papageorgiou, G. C. (2009). Dark-to-light transition in Synechococcus sp. PCC 7942 cells studied by fluorescence kinetics assesses plastoquinone redox poise in the dark and photosystem II fluorescence component and dynamics during state 2 to state 1 transition. Photosynthesis Research, 99(3), 243-255.

Tsygankov, A. A., Kosourov, S. N., Tolstygina, I. V., Ghirardi, M. L., \& Seibert, M. (2006). Hydrogen production by sulfur-deprived Chlamydomonas reinhardtii under photoautotrophic conditions. International Journal of Hydrogen Energy, 31(11), 1574-1584.

Tsygankov, A. A., Kosourov, S. N., Seibert, M., \& Ghirardi, M. L. (2002). Hydrogen photoproduction under continuous illumination by sulfur-deprived, synchronous Chlamydomonas reinhardtii cultures. International Journal of Hydrogen Energy, 27(11), 1239-1244.

Tsygankov, A. A., Kosourov, S. N., Tolstygina, I. V., Ghirardi, M. L., \& Seibert, M. (2006). Hydrogen production by sulfur-deprived Chlamydomonas reinhardtii under photoautotrophic conditions. International Journal of Hydrogen Energy, 31(11), 1574-1584.

Turner, J., Sverdrup, G., Mann, M. K., Maness, P. C., Kroposki, B., Ghirardi, M., \& Blake, D. (2008). Renewable hydrogen production. International Journal of Energy Research, 32(5), 379-407.

Vass, I., Kirilovsky, D., \& Etienne, A. L. (1999). UV-B radiation-induced donor-and acceptor-side modifications of photosystem II in the cyanobacterium Synechocystis sp. PCC 6803. Biochemistry, 38(39), 12786-12794. 
Velthuys, B. R. (1981). Electron-dependent competition between plastoquinone and inhibitors for binding to photosystem II. FEBS Letters, 126(2), 277-281.

Vignais, P. M., \& Billoud, B. (2007). Occurrence, classification, and biological function of hydrogenases: an overview. Chemical Reviews, 107(10), 4206-4272.

Vignais, P. M., Billoud, B., \& Meyer, J. (2001). Classification and phylogeny of hydrogenases. FEMS Microbiology Reviews, 25(4), 455-501.

Volbeda, A., Montet, Y., Vernède, X., Hatchikian, E. C., \& Fontecilla-Camps, J. C. (2002). High-resolution crystallographic analysis of Desulfovibrio fructosovorans [NiFe] hydrogenase. International Journal of Hydrogen Energy, 27(11), 1449-1461.

Volgusheva, A., Styring, S., \& Mamedov, F. (2013). Increased photosystem II stability promotes $\mathrm{H}_{2}$ production in sulfur-deprived Chlamydomonas reinhardtii. Proceedings of the National Academy of Sciences USA 110(18), 7223-7228.

Weaver, P. F., Lien, S., \& Seibert, M. (1980). Photobiological production of hydrogen. Solar Energy, 24(1), 3-45.

White, A. L., \& Melis, A. (2006). Biochemistry of hydrogen metabolism in Chlamydomonas reinhardtii wild type and a Rubisco-less mutant. International Journal of Hydrogen Energy, 31(4), 455-464.

Winkler, M., Heil, B., Heil, B., \& Happe, T. (2002). Isolation and molecular characterization of the [Fe]-hydrogenase from the unicellular green alga Chlorella fusca. Biochimica et Biophysica Acta (BBA)-Gene Structure and Expression, 1576(3), 330-334.

Winkler, M., Hemschemeier, A., Gotor, C., Melis, A., \& Happe, T. (2002). [Fe]-hydrogenases in green algae: photo-fermentation and hydrogen evolution under sulfur deprivation. International Journal of Hydrogen Energy, 27(11), 1431-1439.

Winkler, M., Maeurer, C., Hemschemeier, A., \& Happe, T. (2004). The isolation of green algal strains with outstanding $\mathrm{H}_{2}$ productivity. (pp. 103-116). Elsevier Science, Oxford.

Wolf, I., Buhrke, T., Dernedde, J., Pohlmann, A., \& Friedrich, B. (1998). Duplication of hyp genes involved in maturation of [NiFe] hydrogenases in Alcaligenes eutrophus H16. Archives of Microbiology, 170(6), 451-459.

Wraight, C. A. (1981). Oxidation-reduction physical chemistry of the acceptor quinone complex in bacterial photosynthetic reaction centers: evidence for a new model of herbicide activity. Israel Journal of Chemistry, 21(4), 348-354.

Wu, S., Li, X., Yu, J., \& Wang, Q. (2012). Increased hydrogen production in co-culture of Chlamydomonas reinhardtii and Bradyrhizobium japonicum. Bioresource Technology, 123, 184-188. 
Wykoff, D. D., Davies, J. P., Melis, A., \& Grossman, A. R. (1998). The regulation of photosynthetic electron transport during nutrient deprivation in Chlamydomonas reinhardtii. Plant Physiology, 117(1), 129-139.

Xuefeng L. (2014). Biofuels: From Microbes to Molecules. Caister Academic Press.

Zhang, L., Happe, T., \& Melis, A. (2002). Biochemical and morphological characterization of sulfur-deprived and $\mathrm{H}_{2}$ producing Chlamydomonas reinhardtii (green alga). Planta, 214(4), $552-561$.

Zirngibl, C., Dongen, W., Schwörer, B., Bünau, R., Richter, M., Klein, A., \& Thauer, R. K. (1992). $\mathrm{H}_{2}$-forming methylenetetrahydromethanopterin dehydrogenase, a novel type of hydrogenase without iron-sulfur clusters in methanogenic archaea. European Journal of Biochemistry, 208(2), 511-520. 